\title{
5-Aminopyrazole as precursor in design and synthesis of fused pyrazoloazines
}

\author{
Ranjana Aggarwal ${ }^{\star}$ and Suresh Kumar
}

\author{
Review \\ Address: \\ Department of Chemistry, Kurukshetra University, \\ Kurukshetra-136119, Haryana, India \\ Email: \\ Ranjana Aggarwal* - ranjanaaggarwal67@gmail.com; Suresh Kumar - \\ sureshprocha@gmail.com \\ * Corresponding author \\ Keywords: \\ 5-aminopyrazoles; fused pyrazole derivatives; pyrazolopyridines; \\ pyrazolopyrimidines; pyrazolotriazines
}

\begin{abstract}
The condensation of 5-aminopyrazole with various bielectrophilic moieties results in the formation of pyrazoloazines, an interesting array of fused heterocyclic systems. The development of new synthetic routes towards pyrazoloazines for their biological and medicinal exploration is an attractive area for researchers throughout the world. The present review focuses on various synthetic methods developed in the last decade for the synthesis of differently substituted pyrazoloazines by a broad range of organic reactions by means of 5-aminopyrazole as a precursor.
\end{abstract}

\section{Review}

Pyrazole and its derivatives are known to exhibit significant biological and pharmacological activities such as: anticancer $[1,2]$, anti-inflammatory [3,4], antioxidant [5], antibacterial [6-8], analgesic [9], antiviral [10,11], antimicrobial [12,13], antifungal [6], antiglycemic [14], antiamoebic [15] and antidepressive $[16,17]$. Considering the immense biological properties pyrazole is one of the most widely studied nitrogen-containing heterocyclic nuclei. Fused pyrazole derivatives are composed of the pyrazole nucleus attached to other heterocyclic moieties which enable them to exhibit improved pharmacological activities compared to the isolated fragments. These compounds are currently used in several marketed drugs like

\author{
Beilstein J. Org. Chem. 2018, 14, 203-242. \\ doi:10.3762/bjoc. 14.15 \\ Received: 14 July 2017 \\ Accepted: 08 January 2018 \\ Published: 25 January 2018 \\ Associate Editor: J. Aubé \\ (c) 2018 Aggarwal and Kumar; licensee Beilstein-Institut. \\ License and terms: see end of document.
}




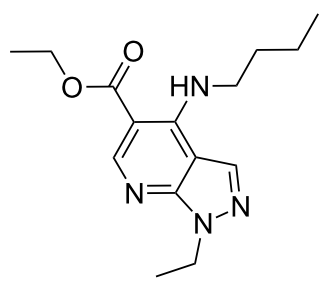

cartazolate (1)<smiles>OC1=NC=NC2NN=CC12</smiles>

allopurinol (4)<smiles>CCN(C(C)=O)c1ccc(-c2ccnc3c(C#N)cnn23)cc1</smiles>

zaleplon (2)<smiles>CC(=O)N(C)c1cccc(-c2ccnc3c(C(=O)c4cccs4)cnn23)c1</smiles>

indiplon (5)<smiles>CCCc1nn(C)c2c(=O)nc(-c3cc(S(=O)(=O)N4CCN(C)CC4)ccc3OCC)[nH]c12</smiles>
sildenafil (3)<smiles>CCOC(=O)c1cnc2c(cnn2CC)c1NN=C(C)C</smiles>

etazolate (6)

Figure 1: Selected examples of drugs with fused pyrazole rings.

plethora of fused pyrazoloazines of potential synthetic and medicinal interest viz pyrazolo[3,4- $b]$ pyridines 7 [18], pyrazolo[1,5-a]pyrimidines 8 [19], pyrazolo[3,4- $d$ ]pyrimidines 9 $[20,21]$, pyrazolo[3,4-b]pyrazines 10 [22], pyrazolo[5,1-c]1,2,4-triazines 11 [23], pyrazolo[1,5-a]-1,3,5-triazines 12 [24], pyrazolo[3,4- $d][1,2,3]$ triazines 13 [25] (Figure 2).

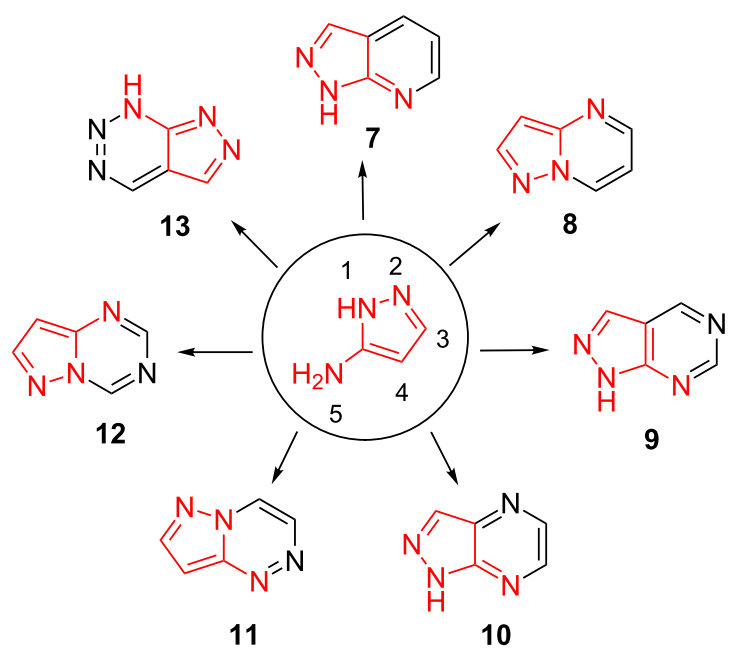

Figure 2: Typical structures of some fused pyrazoloazines from 5-aminopyrazoles.

A number of review articles have been published by us and others highlighting the synthetic and biological aspects of 5-aminopyrazoles [26-28] as well as on the synthesis of fused pyrazole derivatives [25]. However, a perusal of literature reveals that the importance of 5-aminopyrazoles as synthetic precursors for fused heterocycles has not been reported till now to the best of our knowledge. Recent literature shows resurgence of interest in the chemistry and bioactivity of 5-aminopyrazole derivatives leading to improvements in several already known reactions and syntheses of various fused heterocyclic derivatives with various biological activities. Considering the synthetic importance of 5-aminopyrazoles and synthesis of fused pyrazole derivatives with the need for a more general collection, herein we report an exhaustive overview of the main developments in the last decade in the chemistry of 5-aminopyrazoles for the design and synthesis of fused pyrazoloazines.

\section{The typical reactivity of 5-aminopyrazoles}

5-Aminopyrazoles are polyfunctional compounds possessing three typical nucleophilic sites: $4-\mathrm{CH}, 1-\mathrm{NH}$ and $5-\mathrm{NH}_{2}$ with the following reactivity order: $5-\mathrm{NH}_{2}>1-\mathrm{NH}>4-\mathrm{CH}$. These positions have been used to construct various fused heterocyclic rings where 5-aminopyrazoles undergo cyclization and cycloaddition on reaction with bielectrophiles. Due to the large number of references, reactions of 5-aminopyrazoles with various reagents to construct a six membered ring with pyrazole are discussed. The synthetic methods have been arranged in order of the ascending number of heteroatoms in the azine ring. The systematic arrangement in this review explores the possibility of providing practical guidance to synthetic chemists for further research.

\section{Synthesis of pyrazolo[3,4-b]pyridines}

Pyrazolo[3,4- $b]$ pyridines are important fused heterocycles due to their well-known synthetic and medicinal potential as good vasodilators [29], hypotensive [30], HIV reverse transcriptase inhibitors [31], protein kinase inhibitors [32], antiallergic [33], antioxidant [34] and as fungicide [35]. Also, the pyrazolo[3,4$b$ ]pyridine ring system is a key structure in drug discovery and 
has become the main component in many medicinally important compounds. The large number of synthetic routes to pyrazolo $[3,4-b]$ pyridines and their applications brings great interest in this area. The most commonly applied method for the preparation of pyrazolo[3,4- $b]$ pyridines uses 5-aminopyrazole as synthetic precursor [36-39]. Regardless to substantial studies in this field, researchers are still focused to provide convenient regioselective synthetic methods with mild conditions and good yields of the reactions $[40,41]$.

Aggarwal et al. [42] reported the regiospecific synthesis of 4-trifluoromethyl- $1 H$-pyrazolo[3,4-b]pyridines $\mathbf{1 8}$ by the reaction of 5-aminopyrazole 16 with trifluoromethyl- $\beta$-diketones 17 in refluxing acetic acid (Scheme 1). In the same report the other regioisomers 6-trifluoromethylpyrazolo[3,4-b]pyridines 20 were obtained under multicomponent solvent-free conditions by the reaction of hydrazine $\mathbf{1 4}, \beta$-ketonitrile 15 and $\beta$-diketone 17 as an exclusive product. The structures of both the regioisomers have been confirmed unambiguously by HMBC, HMQC and
${ }^{19} \mathrm{~F}$ NMR studies. The authors proposed that trifluoromethyl- $\beta-$ diketone exists mainly in keto form $\mathbf{1 7}$ under solvent-free conditions whereas under solvent-mediated conditions the enolic form 21 towards the carbonyl carbon that carries the $\mathrm{CF}_{3}$ group is predominant. The keto form 17 results in the formation of 6-trifluoromethylpyrazolo[3,4- $b]$ pyridines 20 by attack of the $5-\mathrm{NH}_{2}$ group (from 5-aminopyrazole 16) on the more electrophilic carbonyl group attached to $\mathrm{CF}_{3}$ (from trifluoromethyl- $\beta$-diketones 17) whereas the enolic form 21 reacts with the less nucleophilic C-4 of 5-aminopyrazole and leads to the formation of $4-\mathrm{CF}_{3}$ product $\mathbf{1 8}$. The formation of acetamide 19 as byproduct under solvent-mediated conditions was also observed due to the reaction of $\mathrm{NH}_{2}$ group with acetic acid.

Bardajee et al. [43] reported the synthesis of ethyl 1,3,4-triphenyl-1H-pyrazolo[3,4-b]pyridine-6-carboxylate (23) from the reaction of 5-aminopyrazole $(\mathrm{R}=\mathrm{Ph}, \mathbf{1 6})$ and ethyl 2,4-dioxo-4phenylbutanoate (22, Scheme 2). The presence of an electronwithdrawing group on the aryl ring provided higher yields due

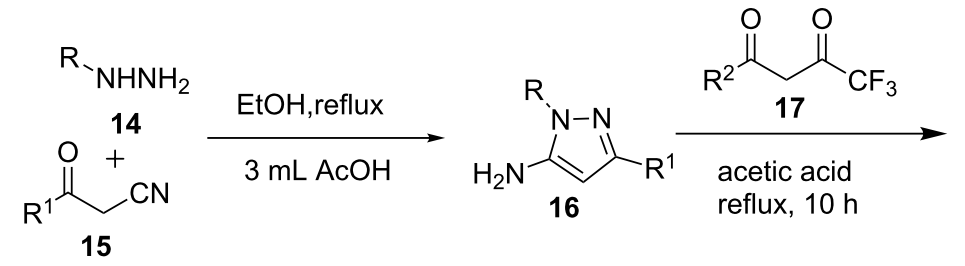<smiles>[R]c1cc(C(F)(F)F)c2c([R])nn([R])c2n1</smiles>

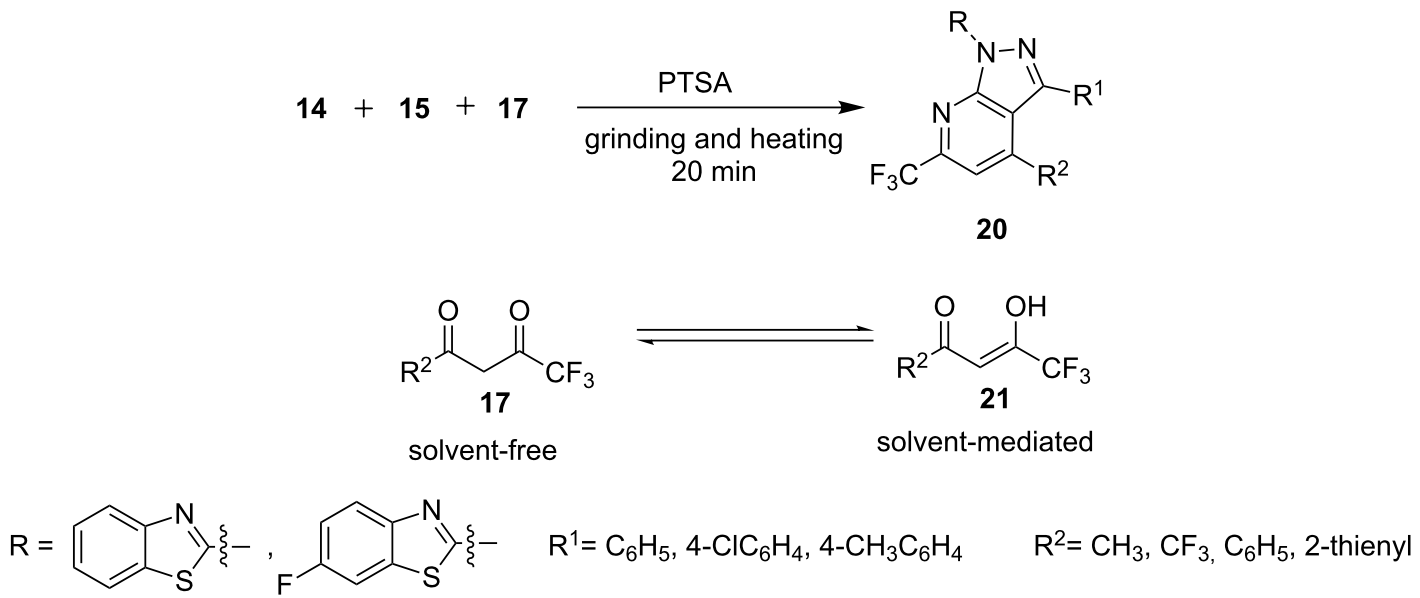

R 18<smiles>[R]c1cc(N)n(P)n1</smiles>

16<smiles>[R]C(=O)CC(=O)C(=O)OCC</smiles>

22

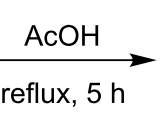

$\mathrm{R}^{1}=\mathrm{CH}_{3}, \mathrm{Ph}$

$\mathrm{R}^{2}=\mathrm{Ph}, 4-\mathrm{CH}_{3}-\mathrm{Ph}, 4-\mathrm{Cl}-\mathrm{Ph}, 4-\mathrm{Br}-\mathrm{Ph}, 4-\mathrm{O}$<smiles>[R]c1cc(C(=O)OCC)nc2c1c([R])nn2-c1ccccc1</smiles> 
to the increased electrophilicity of the carbonyl carbon. Electron-donating groups on the contrary decreased the electrophilicity of the carbonyl carbon and hence resulted in lower yields

The synthesis of 3-methyl-1,4,6-triaryl-1H-pyrazolo[3,4b]pyridines 25 was described by Shi et al. [44] from the reaction of 3-methyl-1-phenyl-1H-pyrazol-5-amine $(\mathrm{R}=\mathrm{Ph}$, $\mathrm{R}^{1}=\mathrm{Me}, \mathbf{1 6}$ ) and $\alpha, \beta$-unsaturated ketones 24 (Scheme 3 ) in the ionic solvent [bmim] $\mathrm{Br}$ at $90^{\circ} \mathrm{C}$ with excellent yield. Variation of the aryl substituents on the $\alpha, \beta$-unsaturated ketones $\mathbf{2 4}$ has no significant effect on the reaction. The reaction was proposed to occur through a sequence of Michael addition, cyclization, dehydration and aromatization reactions. The use of ionic liquids (non-volatile solvents) over toxic organic solvents makes it an environmentally benign process $[45,46]$.

The synthesis of isomeric tetracyclic pyrazolo[3,4-b]pyridinebased coumarin chromophores $\mathbf{2 7}$ and $\mathbf{2 8}$ was reported by Chen et al. [47] starting from 7-diethylaminocoumarin-3-aldehyde (26) and 5-aminopyrazole derivatives $\mathbf{1 6}$ (Scheme 4). The structure of the synthesized compounds was confirmed by X-ray crystallography, ${ }^{1} \mathrm{H}$ and ${ }^{13} \mathrm{C}$ NMR and HRMS studies. The relationships between the structures and chemical properties of these compounds were also investigated by techniques like fluorescence spectroscopy, single photon counting technique, cyclic voltammetry, thermogravimetric analysis, and DFT calculations.

Boruah et al. $[48,49]$ developed an efficient method for the construction of regioisomeric 1,3,4-trisubstituted pyrazolo[3,4$b$ ]pyridines 32 and 34 (Scheme 5). In situ cyclocondensation of $\beta$-halovinyl aldehydes 29 with 5 -aminopyrazoles $(\mathrm{R}=\mathrm{Ph}, \mathbf{1 6})$ under Heck conditions in the presence of $\mathrm{Pd}(\mathrm{OAc})_{2}$ with xantphos (4,5-bis(diphenylphosphino)-9,9-dimethylxanthene) gave 6-substituted pyrazolo[3,4-b]pyridines 34 . On the other hand, isolated imine intermediate $\mathbf{3 0}$ under similar conditions provided 4-substituted pyrazolo[3,4-b]pyridine 31 in DMF (Scheme 5). This intramolecular coupling reaction provided highly efficient synthetic procedure for the design and synthesis of pyrazolo[3,4-b]pyridine-nucleus-based pharmacological agents with high regioselectivity.

Working on similar lines Boruah et al. [49] further explored the reactivity of 5-aminopyrazoles $\mathbf{1 6}$ with $\beta$-halovinyl/aryl aldehydes 33 under conventional heating and microwave conditions in DMF and DMSO with $\mathrm{Pd}(\mathrm{OAC})_{2}(2.5 \mathrm{~mol} \%)$ catalyst with $\mathrm{PPh}_{3}$ as ligand (Scheme 5). Interestingly, high yields of the corresponding pyrazolo[3,4-b]pyridines 34 were obtained when reactions were carried under solvent-free microwave irradiation. The synthesized pyrazolo[3,4-b]pyridines have shown potential<smiles>[X]c1ccc(C=CC(=O)c2ccc([Y])cc2)cc1</smiles>

$\mathrm{X}=\mathrm{CH}_{3}, \mathrm{Cl}, \mathrm{Br}, \mathrm{F}, \mathrm{OCH}_{3} \quad \mathrm{Y}=\mathrm{Cl}, \mathrm{CH}_{3}, \mathrm{NO}_{2}, \mathrm{OCH}_{3}$<smiles></smiles> 


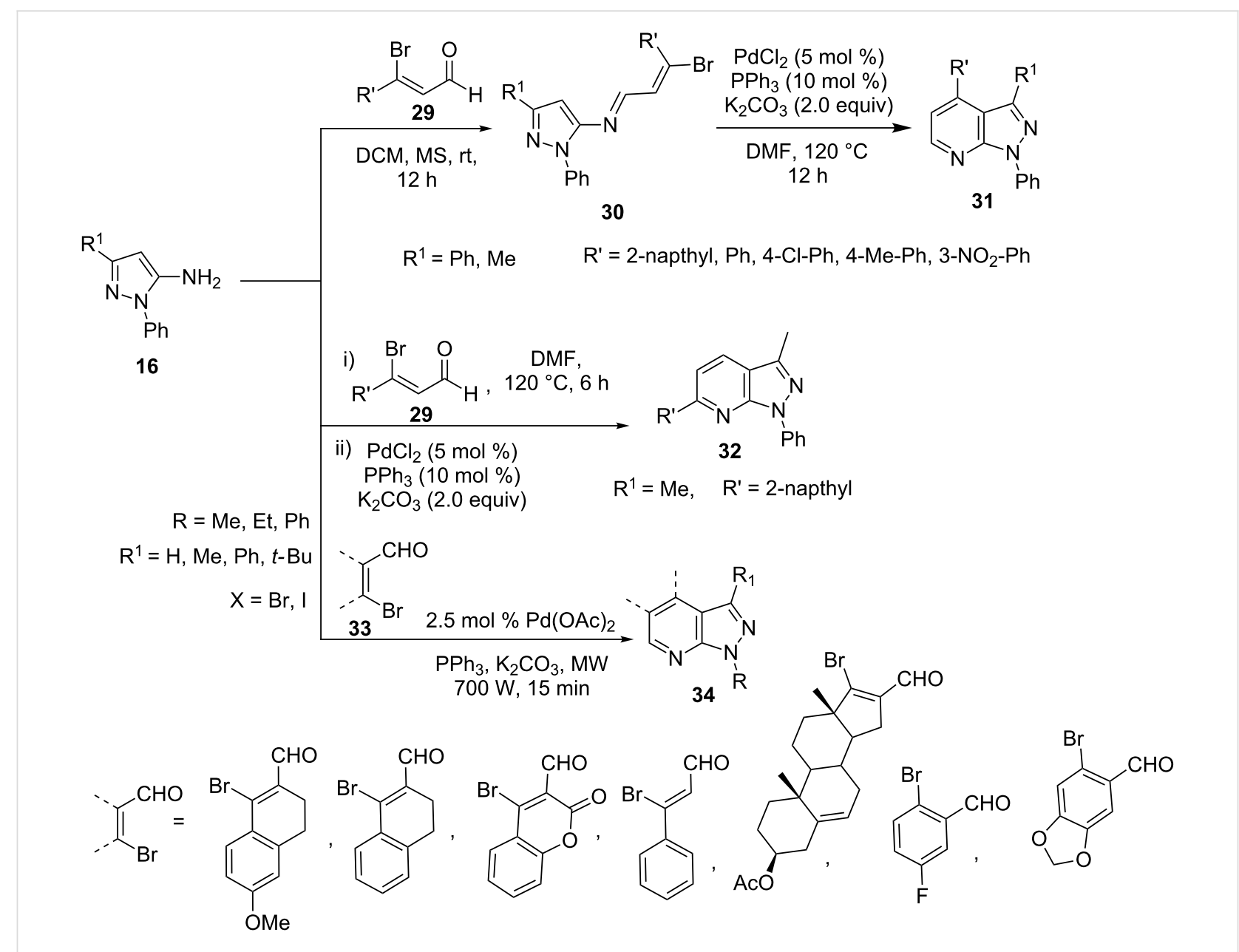

Scheme 5: Synthesis of 6-substituted pyrazolo[3,4-b]pyridines under Heck conditions

cytotoxic activity against cervical HeLa and prostate DU 205 cancer cell lines.

A similar in situ intramolecular cyclization of 5-aminopyrazole4-caroxylate 35 with $\beta$-haloaldehydes 36 via the corresponding imine derivative was carried out in presence of $\mathrm{Pd}\left(\mathrm{PPh}_{3}\right)_{2} \mathrm{Cl}_{2}$ (1.0 mol \%), $\mathrm{Cu}_{2} \mathrm{O}(1.0 \mathrm{~mol} \%), 1,10$-phenanthroline (2.0 mol \%), TBAI (6 mol \%), by Batra et al. [50] to generate the pyrazolo[3,4-b]pyridine nucleus 37 (Scheme 6).

Aziz et al. [51] developed an acid-catalyzed synthesis of pyrazolo[3,4- $b$ ]pyridine derivatives $\mathbf{4 0}$ through the reaction of enaminone 38 with 5 -aminopyrazole $(\mathrm{R}=\mathrm{Ph}, \mathbf{1 6})$ in acetic acid (Scheme 7). The proposed reaction mechanism involves the generation of new enaminone intermediate 39 which underwent condensation and cyclization within C-4 of 5-aminopyrazole and the carbonyl group of the enaminone to generate pyrazolo[3,4-b]pyridine derivatives 40. However, the formation of pyrazolo[1,5-a]pyrimidine 41, a structural isomer of $\mathbf{4 0}$ was obtained when 1-NH-5-aminopyrazole $(\mathrm{R}=\mathrm{H}, \mathbf{1 6})$ was condensed with 38. It was attributed to cyclocondensation between 1-NH (5-aminopyrazole) and the carbonyl carbon of the enaminone. The compounds were found to have cytotoxicity against the normal fibroblast (BHK) cell line and antitumor activity against the colon cancer cell line CaCO-2.

Lin et al. [52] developed the synthesis of pyrazolo[3,4- $b]$ pyridine derivatives 45 via aza-Diels-Alder reaction of pyrazolylimines 43 with maleimides 44 (Scheme 8). Pyrazolylimines 43 were in turn obtained from the reaction of 5-aminopyrazole 16 with diisopropylformamide dimethyl acetal ( $\mathrm{R}^{\prime}=$ isopropyl, 42). The reactions were carried out with various metal catalysts in acetic acid and acetonitrile solvents but reactions carried in acetic acid in presence of silica gel impregnated with indium trichloride provided the best results. Júnior et al. [53] also used $N, N$-dimethylpyrazoylimines $\mathbf{4 2}$ with $N$-arylmaleimides 44 in a solvent-free methodology based on microwaveassisted $\left(80 \mathrm{~W}, 80^{\circ} \mathrm{C}, 1.5 \mathrm{~h}\right)$ hetero-Diels-Alder reaction for the synthesis of pyrazolo[3,4-b]pyridine derivatives 45 (Scheme 8). 


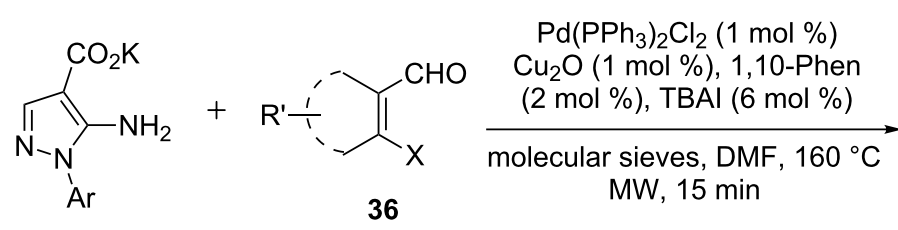<smiles>[R1]1CCc2cnc3[nH]ncc3c2C1</smiles>

37

35

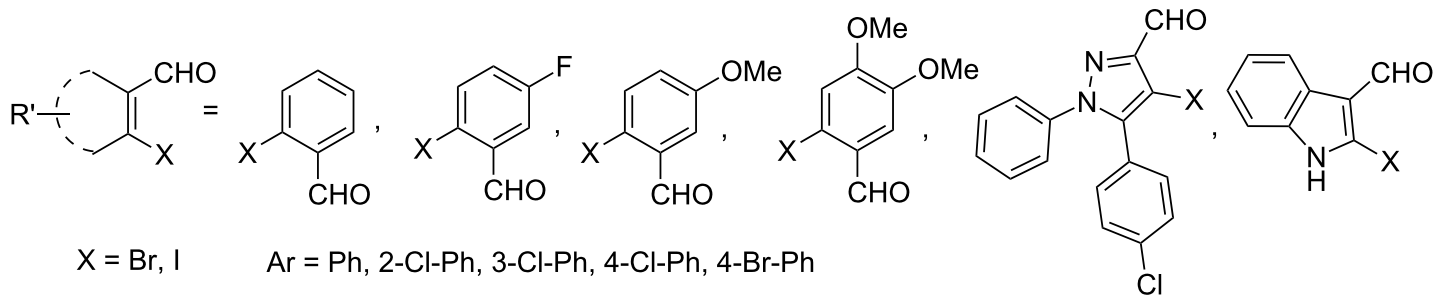<smiles>[R]c1cc(N)n([R])n1</smiles>

38

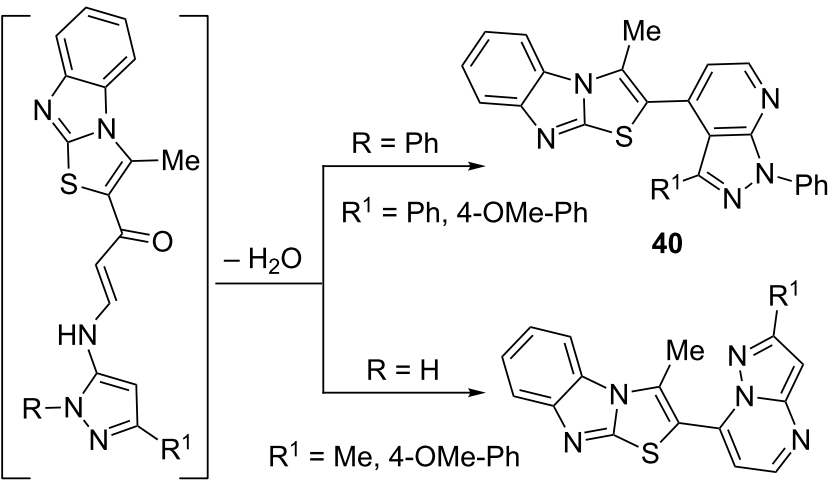

39
41

$$
\mathrm{R}=\mathrm{H}, \mathrm{Ph} \quad \mathrm{R}^{1}=\mathrm{Me}, \mathrm{Ph}, 4-\mathrm{MeO}-\mathrm{Ph}
$$

Scheme 7: Acid-catalyzed synthesis of pyrazolo[3,4-b]pyridines via enaminones.

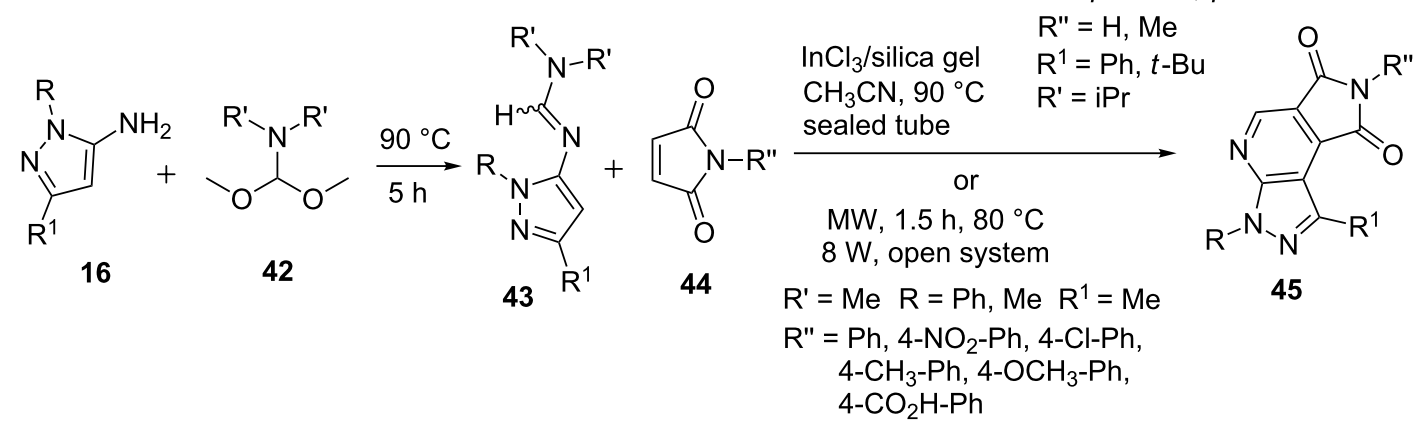

Scheme 8: Synthesis of pyrazolo[3,4-b]pyridines via aza-Diels-Alder reaction.

Jiang et al. [54] described the synthesis of macrocyclane-fused pyrazolo[3,4-b]pyridine derivatives 49 by the reaction of 5-aminopyrazole derivative 46 , arylaldehydes 47 and cyclic ke- tones 48 in various solvents like acetonitrile, ethylene glycol, acetic acid, DMF under MW conditions at $80^{\circ} \mathrm{C}$ (Scheme 9). The best results ( $72-80 \%$ yields) were obtained by carrying out 


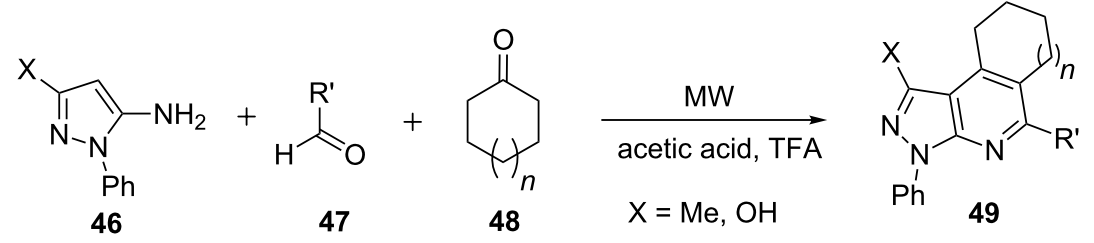

$\mathrm{R}^{\prime}=4-\mathrm{Me}-\mathrm{Ph}, 4-\mathrm{Meo}-\mathrm{Ph}, 4-\mathrm{Br}-\mathrm{Ph}, 2-\mathrm{Cl}-\mathrm{Ph}, 2$-thienyl, 2,3-diOMe-Ph $\quad n=2,3,7$

Scheme 9: Synthesis of macrocyclane fused pyrazolo[3,4-b]pyridine derivatives.

the reaction in acetic acid with the addition of TFA as promoter at $80{ }^{\circ} \mathrm{C}$ to $140{ }^{\circ} \mathrm{C}$.

A three-component reaction of 5-aminopyrazole 16, 4-hydroxycoumarin (50) and aldehydes $\mathbf{4 7}$ was studied by Liu et al. [55] in various solvents like acetonitrile, dichloromethane, toluene and DMSO in the presence of catalysts like $\mathrm{ZrCl}_{4}, \mathrm{InCl}_{3}, \mathrm{FeCl}_{3}$, L-proline etc. (Scheme 10). Whereas the reaction in acetic acid/ acetonitrile (1:5) provided 4,7-dihydro-1 $H$-pyrazolo[3,4-b]pyridine derivatives 51, dimethyl sulfoxide/acetic acid (5:1) yielded the corresponding aromatized pyrazolo[3,4-b]pyridine derivatives 52 exclusively. In acetic acid/ethanol combination an unexpected product 4,5-dihydro- $1 H$-pyrazolo[3,4-b]pyridine$6(7 H)$-one 53 was formed due to $\mathrm{C}-\mathrm{O}$ bond cleavage from cyclic ester $\mathbf{5 1}$

Bazgir et al. [56] described the synthesis of spiro[indoline-3,4'pyrazolo[3,4-b]pyridine]-2,6'(1'H)-diones 55 by an efficient three-component procedure from the reaction of 5 -aminopyrazole 16 and 4-hydroxycoumarin (50) with isatin 54 under ultrasound irradiation in water (Scheme 11). Solvent and catalytic screening for the reaction have shown that water in pres- ence of $p$-TSA at $60{ }^{\circ} \mathrm{C}$ on heating for 6 hours provide best results with excellent yields.

Recently, Wang et al. [57] also described the construction of spiro[indoline-3,4'-pyrazolo[3,4-b]pyridine] derivatives $\mathbf{5 7}$ from the multicomponent reaction of 5-amino-3-hydroxy-1-phenyl$1 H$-pyrazole (46), ketones 56 and isatin 54 in water/acetic acid (3:1) at $90{ }^{\circ} \mathrm{C}$ (Scheme 12).

Quiroga et al. [58] reported the synthesis of the pyrazolo[3,4b]pyridine-spiroindolinone nucleus $\mathbf{5 9}$ with a high degree of regioselectivity without formation of the regioisomeric pyrazolo[1,5- $a$ ]pyrimidine $\mathbf{6 0}$ involving three-component reaction of 5-aminopyrazole 16, isatin 54 and cyclic $\beta$-diketones 58 in aqueous ethanol with $p$-TSA as catalyst (Scheme 13). Bhaumik et al. [59] carried out a similar reaction of 5-aminopyrazole $\left(\mathrm{R}=\mathrm{H}, \mathrm{R}^{1}=\mathrm{Me}, \mathbf{1 6}\right)$, isatin 54 and cyclic-1,3-diones 58 in aqueous ethanol using aluminosilicate nanoparticles catalyst to yield pyrazolo[3,4-b]pyridines 61 (Scheme 13).

Dandia et al. [60] carried out the multicomponent synthesis of spiropyrazolo[3,4-b]pyridines 63 and 64 starting from 5-amino-

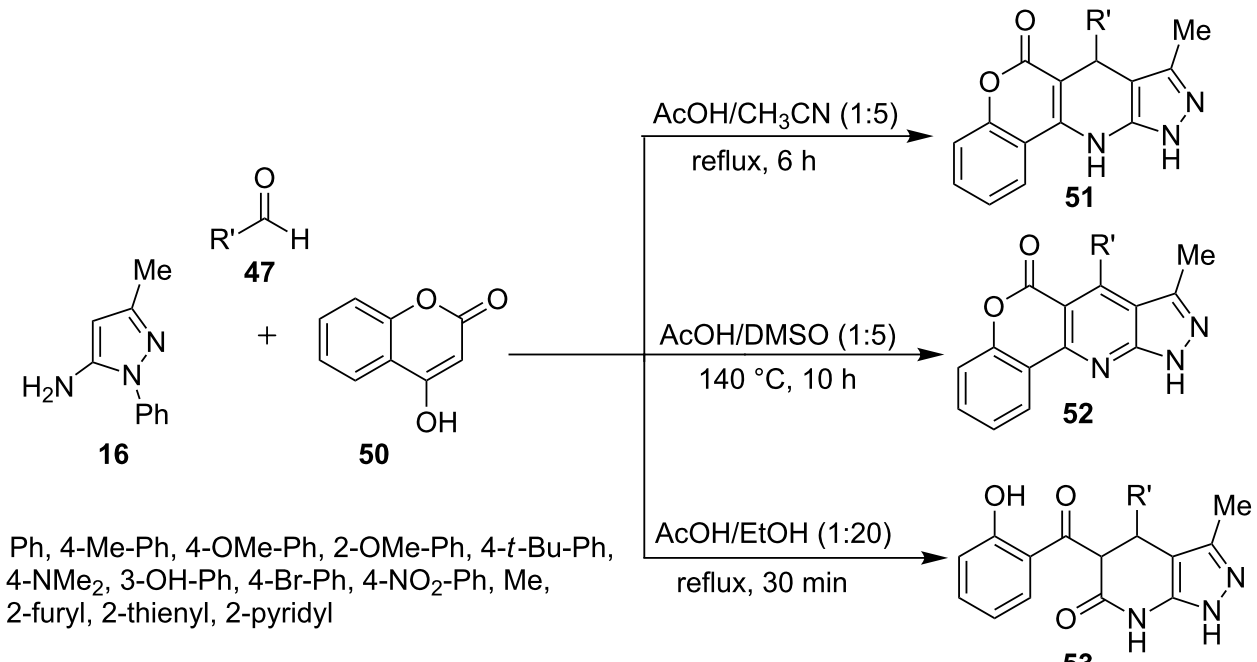


<smiles>[R]n1nc(-c2ccccc2)cc1N</smiles>

16<smiles>[R]c1ccc2c(c1)C(=O)C(=O)N2[R]</smiles>

54

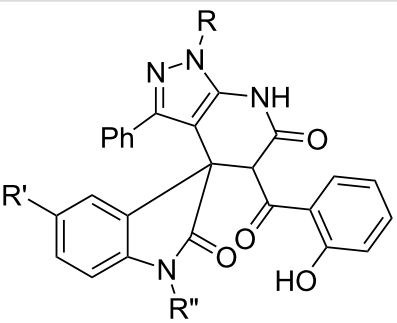

55

$$
\mathrm{R}=\mathrm{Ph}, 4-\mathrm{NO}_{2}-\mathrm{Ph} \quad \mathrm{R}^{\prime}=\mathrm{H}, \mathrm{Br}, \mathrm{NO}_{2}, \mathrm{Me} \quad \mathrm{R}^{\prime \prime}=\mathrm{H}, \mathrm{Me}, \mathrm{Et}, \mathrm{CH}_{2} \mathrm{Ph}
$$<smiles>[R][Y]1[R17]([Z19])N2C(=O)C(=O)c3c1cccc32</smiles>

$\mathrm{R}^{\prime}=\mathrm{H}, 5-\mathrm{F}, 7-\mathrm{F}, 7-\mathrm{Cl}, 5-\mathrm{Br}, 6-\mathrm{Br}, 5-\mathrm{CH}_{3}$<smiles>[R]C1=C([R])C2(C(=O)Nc3ccccc32)C([R])=C2NC(=O)NC12</smiles>

57<smiles>[R]CC([R])=O</smiles><smiles>O=C1CCc2ccccc21</smiles><smiles>O=C1CCc2cc(Cl)ccc21</smiles><smiles>O=C1CCCc2ccccc21</smiles><smiles>COc1ccc2c(c1)CCCC2=O</smiles>

Scheme 12: Synthesis of spiro[indoline-3,4'-pyrazolo[3,4-b]pyridine] derivatives under conventional heating conditions.

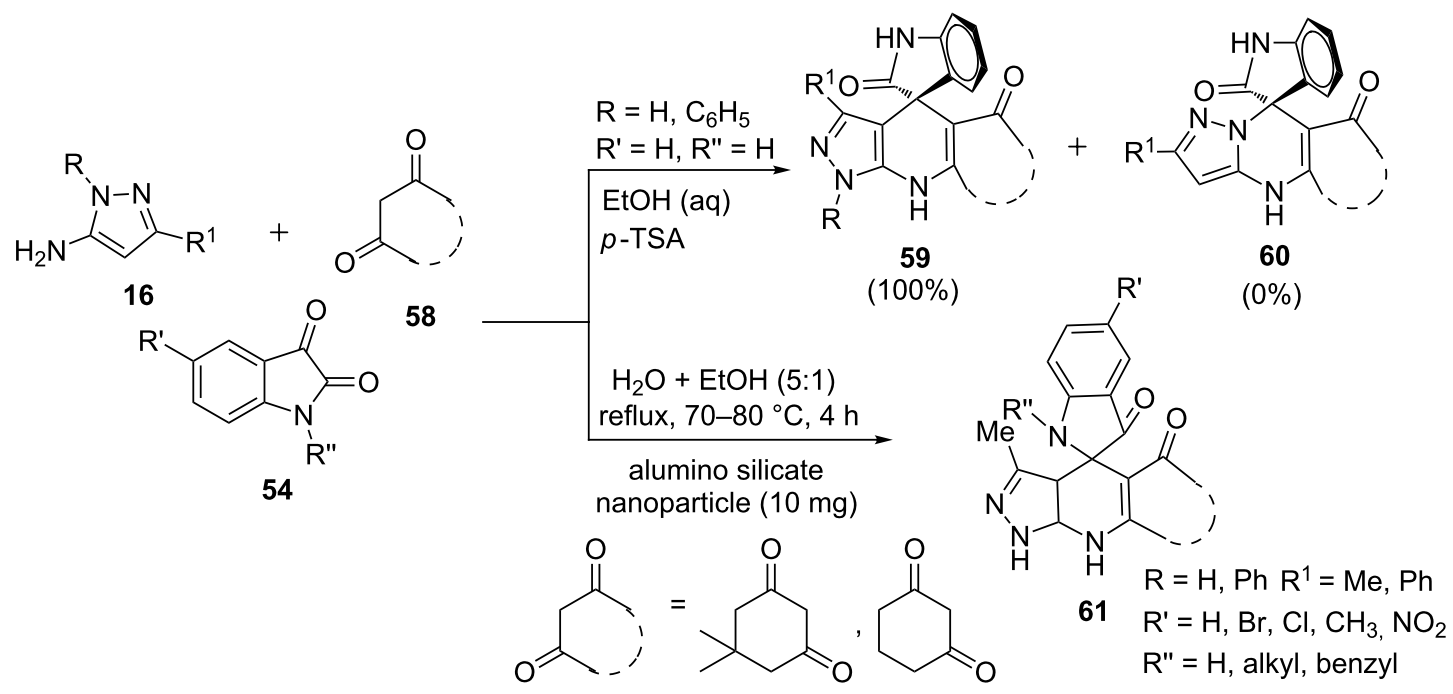<smiles>CCCC1(CC)CC(=O)CC(=O)C1</smiles> 
pyrazole $\left(\mathrm{R}=\mathrm{H}, \mathrm{R}^{1}=\mathrm{Me}, \mathbf{1 6}\right)$, isatin 54 and $\alpha$-cyanoacetic ester 62 or 15 in aqueous-mediated reaction in presence of $\mathrm{NaCl}$. Regioisomeric pyrazolo[1,5-a]pyrimidines $\mathbf{6 5}$ were not formed in any of the tried reaction conditions. An increase in the amount of $\mathrm{NaCl}$ from 2.5 to $10 \mathrm{~mol} \%$ resulted in gradual increase of the yield of the desired product $\mathbf{6 3}$ from $85 \%$ to $89 \%$ and $93 \%$, respectively (Scheme 14). Recently, Jiang et al. [61] have also developed a microwave-assisted synthesis of spiropyrazolo[3,4- $b]$ pyridines 66 via a similar type of three-component reaction of 5-aminopyrazole 16, isatin 54 and 3-oxo-3-phenylpropanenitriles $\mathbf{1 5}$ in acetic acid under microwave irradiation at $80{ }^{\circ} \mathrm{C}$ in just 20 minutes (Scheme 14).

Hao et al. [62] described the unexpected synthesis of naphthoic acid substituted pyrazolo[3,4-b]pyridine derivatives 70 via a three-component reaction of 5 -aminopyrazole $(\mathrm{R}=\mathrm{Me}, \mathbf{1 6})$ with acenaphthenequinone $\mathbf{6 7}$ and $\beta$-ketonitrile derivative 68 in glacial acetic acid instead of expected spiropyrazolo[3,4$b]$ pyridines 69 (Scheme 15). The structures of the products were confirmed by spectral and X-ray crystallographic data. This method provides the first direct conversion of acenaphthenequinone to a naphthoic acid fragment via $\mathrm{C}-\mathrm{C}$ bond cleavage in a single step.

Recently, D. Anand et al. [63] have reported the synthesis of pyrazolo[3,4-b]pyridine derivatives $\mathbf{7 1}$ and $\mathbf{7 2}$ through the multicomponent reaction of 1-aryl-3-indolyl-5-aminopyrazoles 16, cyclic $\beta$-diketones 58 and aryl aldehydes 47 (Scheme 16). The reaction resulted in good yields of pyrazolo[3,4-b]pyridines $\mathbf{7 2}$ but in few cases 4,7-dihydropyrazolo[3,4-b]pyridines $\mathbf{7 1}$ were formed as major product even after prolonged heating. 4,7-Dihydropyrazolo[3,4- $b]$ pyridines 71 were dehydrogenated<smiles>[R][R]O[R20](=O)O[Na]</smiles>

Scheme 14: Microwave-assisted multicomponent synthesis of spiropyrazolo[3,4-b]pyridines<smiles>[R]c1ccc2c(C(=O)CC#N)cn([R2])c2c1</smiles>

$\mathrm{R}^{\prime}=\mathrm{H}$, 4-Me, 5-Me, 6-Me, 7-Me, 5-Br, 4-COOEt

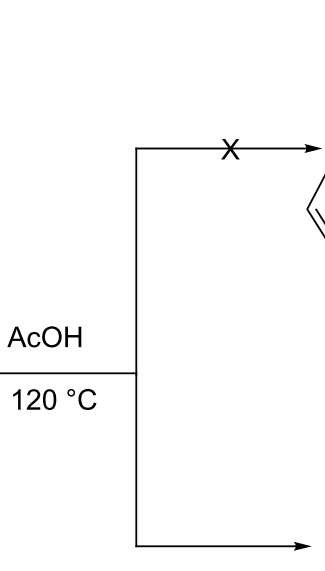

$\mathrm{R}^{\prime \prime}=\mathrm{H}, \mathrm{Me}, \mathrm{Bn}$<smiles>[R][CH]c1cccc2cccc(C)c12</smiles><smiles>[R]c1nnc(C)c2c1NC(c1cn([R7])c3cc[R]cc13)=C(C)C2c1cccc2ccccc12</smiles> 


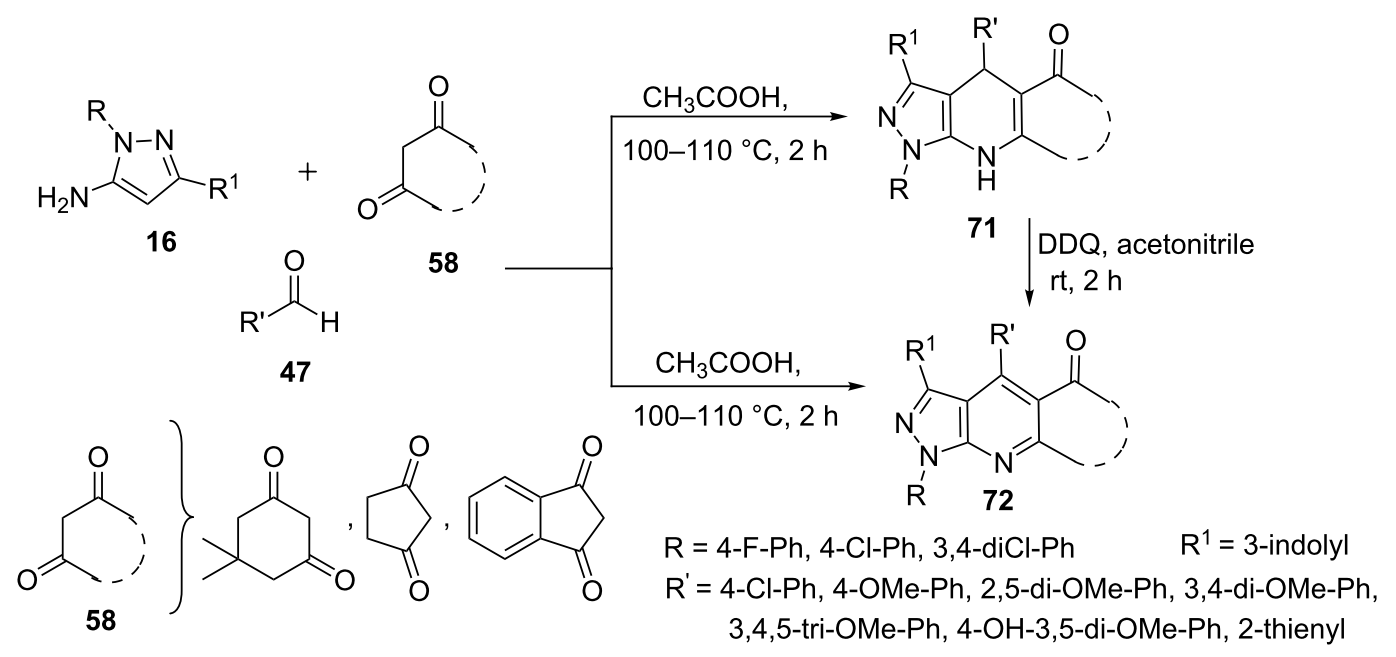

Scheme 16: Multicomponent synthesis of variously substituted pyrazolo[3,4-b]pyridine derivatives.

to their aromatic counterparts $\mathbf{7 2}$ in presence of 2,3-dichloro5,6-dicyanobenzoquinone (DDQ) in acetonitrile.

Insuasty et al. [64] adapted a similar synthetic strategy for the construction of 4,7-dihydropyrazolo[3,4- $b]$ pyridines $\mathbf{7 3}$ and pyrazolo[3,4-b]pyridines $\mathbf{7 4}$ by a three-component reaction of 5 -aminopyrazoles 16, cyclic $\beta$-diketones 58 and heteroaryl aldehydes 47 (Scheme 17). The reaction under conventional heating in DMF provided best results with high yields of the corresponding pyrazolo[3,4-b]pyridines $\mathbf{7 4}$.

The multicomponent reactions of 5-(4-substituted-benzylamino)pyrazoles $\mathbf{7 5}$, cyclic- $\beta$-diketones $\mathbf{5 8}$ and formaldehyde $\left(R^{\prime}=H, 47\right)$ were performed under microwave and conventional heating conditions by Quiroga et al. [65] (Scheme 18).
Both the reaction conditions resulted in the formation of pyrazolo[3,4- $b$ ]pyridine-5-spirocycloalkanediones 76 but an additional compound 3-tert-butyl-1-phenylindeno[2,3-e]pyrazolo[3,4- $b]$ pyridine 77 was formed in the reaction when indandione $\mathbf{5 8}$ was used as $\beta$-diketone which was attributed to the loss of the benzyl fragment from 5-aminopyrazole derivative 75. Microwave-assisted reactions went to completion in very short time (5 $\mathrm{min}$ ) compared to reactions under conventional heating conditions (24 hours).

A three-component reaction of 5-aminopyrazole 16, arylaldehydes $\mathbf{4 7}$ and indandione $\mathbf{5 8}$ under ultrasonic irradiation in ethanol was developed by Nikpassand et al. [66] to synthesize pyrazolo[3,4-b]pyridine derivatives 78 (Scheme 19). Ultrasound-mediated reactions yielded the corresponding pyr-<smiles>[R]C=CC1CCC(=O)CC1=O</smiles>

47

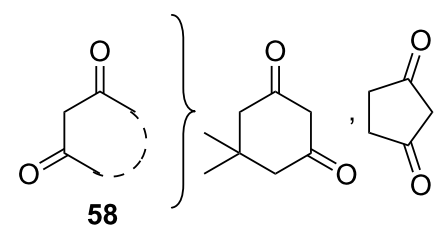<smiles>[R]C1c2c([nH]c3c2c(C)nn3-c2ccccc2)CC2(CC)CCCCC12</smiles><smiles>[R]c1c2c(nc3c1c(C)nn3-c1ccccc1)CC[C@H](C)C2=O</smiles>

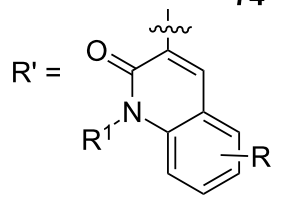

$\mathrm{R}^{1}=\mathrm{H}$, butyl, benzyl $\quad \mathrm{R}=\mathrm{H}, 6-\mathrm{OMe}, 6-\mathrm{Me}, 7-\mathrm{Cl}$ 
<smiles>[R]C(=O)[CH-][CH]</smiles>

47

58

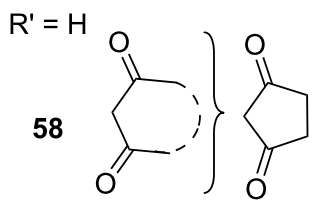<smiles>CC(C)(C)c1cc(NCC#N)n(-c2ccccc2)n1</smiles>

75<smiles>CC(C)(C)[Mg][Mg]</smiles><smiles>[R]C1([R])CC(=O)CC(=O)C1</smiles><smiles>O=C1CC(=O)c2ccccc21</smiles>

$\mathrm{Ar}=\mathrm{Ph}, 4-\mathrm{CH}_{3}-\mathrm{Ph}, 4-\mathrm{CF}_{3}-\mathrm{Ph}, 4-\mathrm{F}-\mathrm{Ph}, 4-\mathrm{Cl}-\mathrm{Ph}$,<smiles>CC(C)(C)c1n[nH]c2c1CC(C(=O)CI)(C(=O)CI)C2</smiles>

Ph 76<smiles></smiles>

77

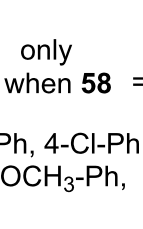<smiles>[R]C=[C-]C(=O)C1C(=O)c2ccccc2C1=O</smiles>

16

47

58<smiles>[R]C1C2=C(Nc3[nH]nc(C)c31)c1ccccc1C2=O</smiles>

78

$\mathrm{R}=$ 2- $\mathrm{NO}_{2}-\mathrm{C}_{6} \mathrm{H}_{4}, 3-\mathrm{NO}_{2}-\mathrm{C}_{6} \mathrm{H}_{4}, 4-\mathrm{NO}_{2}-\mathrm{C}_{6} \mathrm{H}_{4}, 3-\mathrm{Br}_{-}-\mathrm{C}_{6} \mathrm{H}_{4}, 3-\mathrm{Cl}-\mathrm{C}_{6} \mathrm{H}_{4}$, 2,4- $-\mathrm{Cl}_{2}-\mathrm{C}_{6} \mathrm{H}_{4}$, 3-indoyl, 5- $\mathrm{NO}_{2}$-2-furyl

Scheme 19: Ultrasound-mediated three-component synthesis of pyrazolo[3,4-b]pyridines.

azolo[3,4-b]pyridine derivatives $\mathbf{7 8}$ in $4-5$ minutes with $88-97 \%$ yields.

Yao et al. [67] demonstrated that 4-aryl-3-methyl-1-phenyl4,6,8,9-tetrahydropyrazolo[3,4-b]thiopyrano[4,3-e]pyridin$5(1 H)$-one derivatives $\mathbf{8 0}$ could be synthesized from a threecomponent reaction of 5-aminopyrazole $\mathbf{1 6}$, arylaldehyde $\mathbf{4 7}$, and $2 H$-thiopyran-3,5(4H,6H)-dione (79) in glacial acetic acid in presence of ammonium acetate (Scheme 20).

The multicomponent reaction of 5-amino-3-hydroxypyrazoles 82, substituted salicylic aldehydes $\mathbf{8 3}$ and acetylacetic ester $\mathbf{8 1}$ in acetic acid with few drops of piperidine was reported to give 2,3-dihydrochromeno[4,3- $d]$ pyrazolo[3,4- $b]$ pyridine-1,6-diones 84 by Frolova et al. [68] (Scheme 21). The reactions with ethyl benzoylacetate as ketoester component had not provided the corresponding pyrazolo[3,4- $b]$ pyridines which was attributed to the change in the electronic and steric environments. All the synthesized compounds were reported as good antimicrobial agents.

Recently the reaction of $\beta$-ketoesters $\mathbf{8 1}$ as in the three-component reaction with 5-aminopyrazoles $\mathbf{1 6}$ and substituted salicylic aldehydes 83 was also studied by Fan et al. [69]. An extensive survey of catalysts and solvents identified 0.2 equivalents of $\mathrm{FeCl}_{3}$ and ethanol as optimal catalyst and solvent, respectively, with which $o$-hydroxyphenylpyrazolo[3,4- $b]$ pyridine derivatives $\mathbf{8 5}$ were obtained in $89 \%$ yields with no formation of the cyclized isomer chromenopyrazolo[3,4-b]pyridine 86. The reaction in the presence of other catalysts like L-proline, $\mathrm{InCl}_{3}$ and $\mathrm{ZrCl}_{4}$ also resulted in the formation of $o$-hydroxyphenylpyrazolo[3,4- $b]$ pyridine derivatives $\mathbf{8 5}$ but no<smiles>[Z17]C([CH2+])=O</smiles>

$\mathrm{R}^{\prime}=\mathrm{Ph}, 2-\mathrm{Cl}-\mathrm{Ph}, 4-\mathrm{Br}-\mathrm{Ph}, 2-\mathrm{F}-\mathrm{Ph}, 3-\mathrm{Cl}-\mathrm{Ph}, 4-\mathrm{Cl}-\mathrm{Ph}, 4-\mathrm{CH}_{3}-\mathrm{Ph}, 4-\mathrm{OCH}_{3}-\mathrm{Ph}, 3,4,5-$ tri- $\mathrm{OCH}_{3}-\mathrm{Ph}$, 2-thienyl 


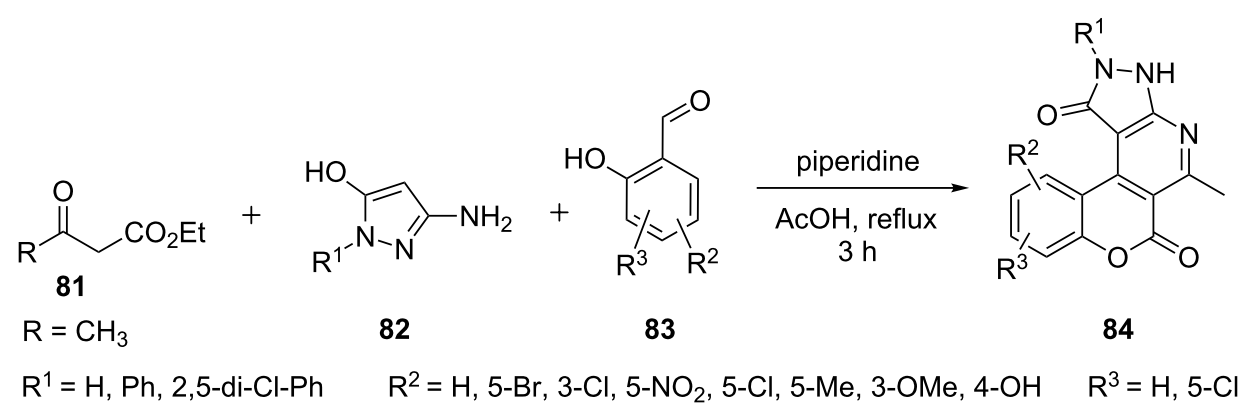

Scheme 21: Synthesis of 2,3-dihydrochromeno[4,3-d]pyrazolo[3,4-b]pyridine-1,6-diones.

product was formed in iodine- and acetic acid-catalyzed reactions (Scheme 22).

Huang et al. [70] investigated a three-component reaction of $\beta$-ketonitriles 15 , 5-aminopyrazole 16 and aldehydes 47 in various organic solvents and ionic liquids to synthesize pyrazolo[3,4-b]pyridine derivative 87 (Scheme 23). Ionic liquids provided high yields of $\mathbf{8 7}$ in very short time with the best results obtained in [bmim] $\mathrm{Br}$ whereas organic solvents resulted in low yields and took longer time for the completion of reaction.

El-borai et al. [71] accomplished the synthesis of pyrazolo[3,4$b$ ]pyridine derivatives $\mathbf{8 8}$ in which the multicomponent reactions of $\beta$-ketonitriles 15, 5-aminopyrazole $\mathbf{1 6}$ and anisalde- hyde (47) were carried out in acetic acid under conventional heating and microwave assistance (Scheme 24). The microwave-assisted reaction provided better yields of pyrazolo[3,4$b$ ]pyridine derivatives $\mathbf{8 8}$ as compared to reactions under conventional heating conditions in short time.

Hill et al. [72,73] reported the synthesis of pyrazolo[3,4$b]$ pyridines 89 from the reaction $\beta$-ketonitriles 15 with 5-aminopyrazole 16 and aldehydes 47 (1 equiv each) in presence of triethylamine ( 2 equiv) by heating the reaction mixture at $90{ }^{\circ} \mathrm{C}$ in DMF for 16 hours followed by treatment with sodium nitrite ( 3 equiv) in acetic acid at ambient temperature. In addition, when the $\mathrm{R}^{1}$ group has significant bulk $\left(\mathrm{R}^{1}=\right.$ tert-butyl) the reaction results in the formation of pyrazolo[1,5- $a$ ]pyrimidine derivative $\mathbf{9 0}$ as an additional product. The authors proposed<smiles>[R]c1cc(N)nn1-c1ccccc1</smiles>

16<smiles>[R]C(=O)CC(=O)OCC</smiles>

81
83<smiles>[R]c1ccc(O)c(-c2c(C(=O)OCC)c([R])nc3c2c([R])nn3-c2ccccc2)c1</smiles>

$85(100 \%)$<smiles>[R]c1nc2c(c([R])nn2-c2ccccc2)c2c1c(=O)oc1cccc([R])c12</smiles>

$86(0 \%)$

$\mathrm{R}^{1}=\mathrm{Me}, \mathrm{Ph} \quad \mathrm{R}=\mathrm{Ph}, \mathrm{Me}, \mathrm{Et}, n-\mathrm{Pr}, \mathrm{CF}_{3} \quad \mathrm{R}^{2}=\mathrm{H}, 4-\mathrm{OMe}, 5-\mathrm{Br}, 3,5-\mathrm{di}-\mathrm{Br}, 5-\mathrm{Cl}, 3,5-\mathrm{di}-\mathrm{Cl}, 5-\mathrm{NO}_{2}$

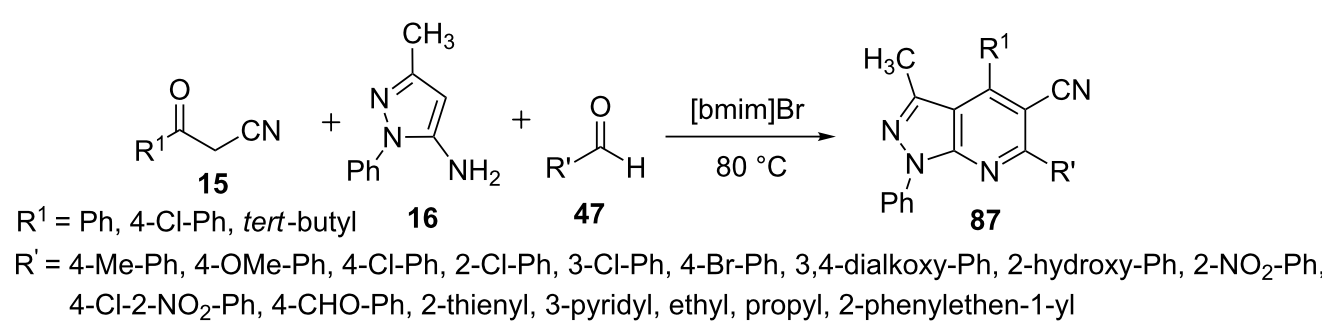


<smiles>[R]C(=O)C[18F]</smiles><smiles>[R]c1ccc([Y])c([R])c1</smiles><smiles>Nc1cc(-c2cccnc2)nn1-c1ccccc1</smiles>

16<smiles>COc1ccc(C=O)cc1</smiles>

47<smiles>[R7]c1nc2c(c(-c3cccnc3)nn2-c2ccccc2)c(-c2ccc(OC)cc2)c1C#N</smiles>

88

where $\mathrm{R}=\mathrm{H}, \mathrm{CH}_{3}, \mathrm{Cl}, \mathrm{F}, \mathrm{NO}_{2} \quad \mathrm{X}=\mathrm{N}, \mathrm{CH}$

Scheme 24: Microwave-assisted synthesis of pyrazolo[3,4-b]pyridines.

that the bulky group had significantly slowed down the rate of electrophilic aromatic substitution at C-4 on $1 H$-pyrazol-5amine due to which the aza-Michael addition becomes competitive at N-1 which ultimately provides pyrazolo[1,5- $a$ ]pyrimidine derivative 90 as additional product (Scheme 25). The synthesized pyrazolo[3,4-b]pyridines $\mathbf{8 9}$ were found to be good mGluR5 positive allosteric modulators (PAMs) and therefore can be used to develop antipsychotic drugs to treat schizophrenia.

In an interesting report Aggarwal et al. [74] described the synthesis of 4,7-dihydropyrazolo[3,4-b]pyridine-5-nitriles 92 from the reaction of $\beta$-ketonitriles $\mathbf{1 5}$ with several aryl/heteroaryl hydrazines 14 in ethanol with a catalytic amount of conc. $\mathrm{HNO}_{3}$ (Scheme 26). The authors carried out the reaction under acidic conditions expecting the formation of the regioisomeric 3/5-aminopyrazoles 16/91 but the reaction under the influence of conc. $\mathrm{HNO}_{3}$ resulted in the formation of an unexpected product which was characterized as 4,7-dihydropyrazolo[3,4-b]pyridine 92 through rigorous spectroscopic studies. However, $\mathrm{X}$-ray crystallographic studies indicated that the 4,7-dihydropyrazolo[3,4- $b$ ]pyridine-5-nitriles 92 underwent aerial oxidation to its aromatic counterpart pyrazolo[3,4-b]pyridine $\mathbf{9 3}$ during crystallization and is propeller in shape. Additionally, non-planar rings due to propeller shape of compound 93 makes it chiral in nature. It was proposed that there is in situ oxidation of ethanol to ethanal by conc. $\mathrm{HNO}_{3}$ which turned the reaction into a multi-component domino assembly of reactants hydrazine 14, $\beta$-ketonitriles 15 and acetaldehyde.

Rahmati [75] carried out a reaction of 5-aminopyrazole 16 with aldehydes 47 and ethyl cyanoacetate (94) in ethanol in presence of $p$-toluenesulfonic acid which resulted in a diastereomeric mixture of cis- and trans-4,5,6,7-tetrahydro-2H-pyrazolo[3,4$b$ ]pyridines 95 . Benzaldehydes 47 with electron withdrawing groups provided better yields of the cis-isomer in slightly higher amounts than the trans-isomer. A four-component reaction having ethyl acetoacetate (81) as fourth component resulted in the formation of the same pyrazolo[3,4-b]pyridine derivative 95 showing no involvement of any additional fourth component (Scheme 27).

Dandia et al. [76] also reported a similar reaction of 5-aminopyrazole 16, arylaldehyde 47 with ethyl cyanoacetate (94) under ultrasound irradiation in presence of $p$-TSA in water for the synthesis of 3-methyl-6-oxo-4-aryl-4,5,6,7-tetrahydro-4H-pyr-

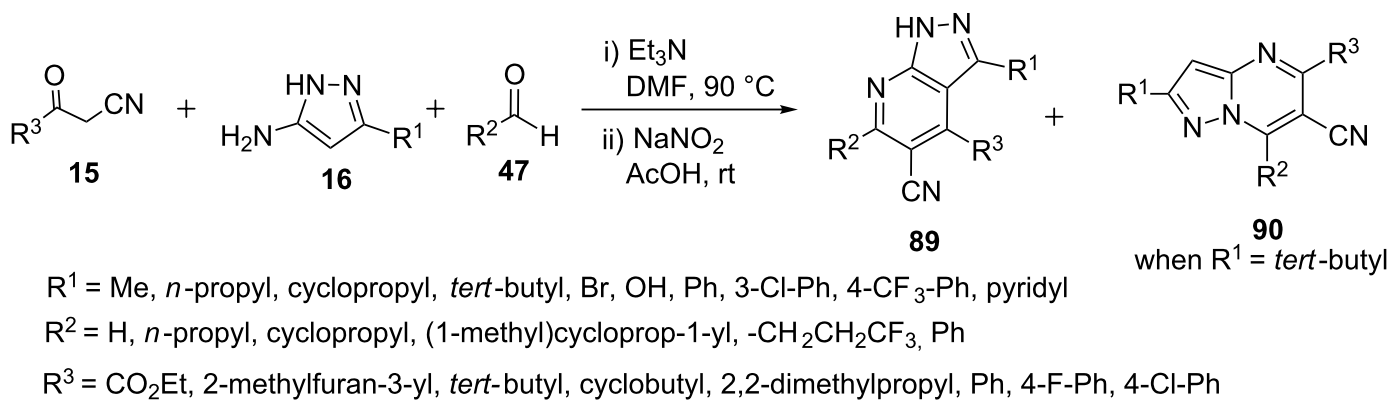




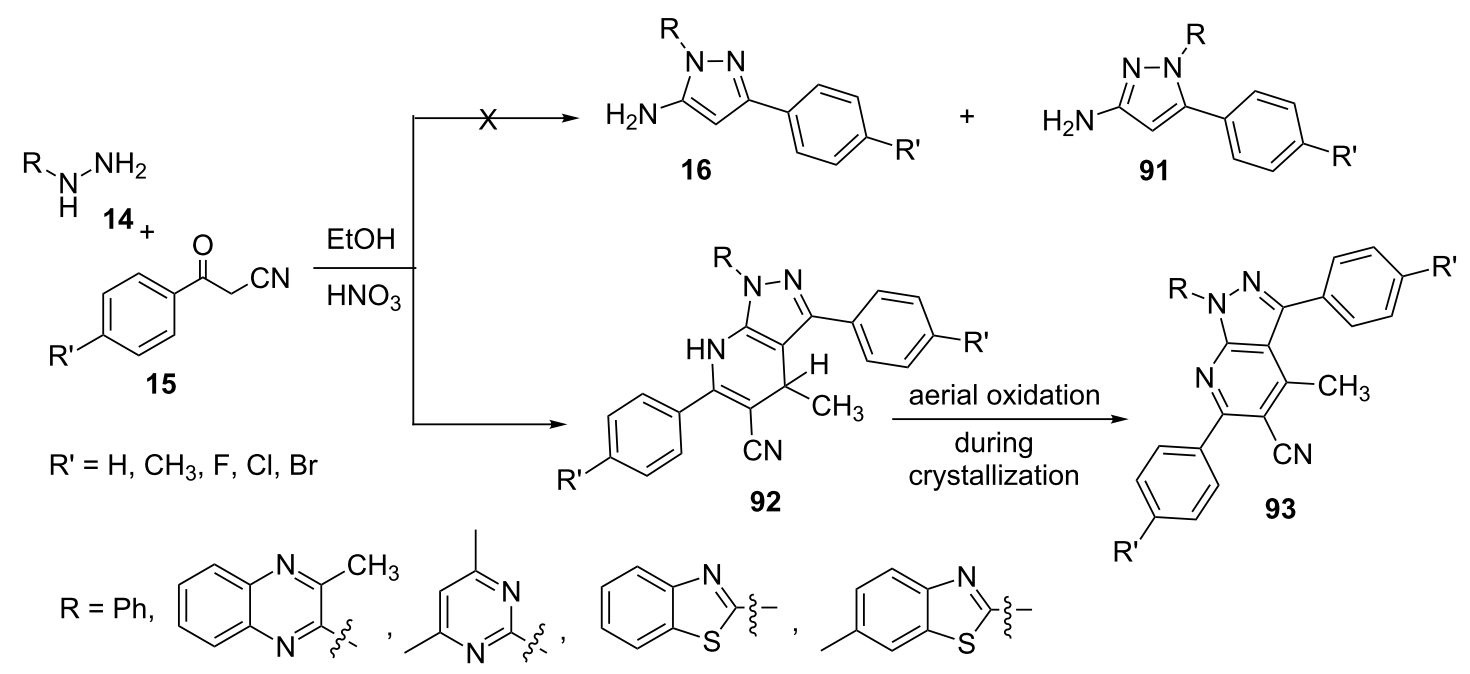

Scheme 26: Unusual domino synthesis of 4,7-dihydropyrazolo[3,4-b]pyridine-5-nitriles.

azolo[3,4-b]pyridine-5-carbonitrile derivatives 95 (Scheme 27). All the synthesized compounds were tested for their effect on corrosion of mild steel (MS) in $1.0 \mathrm{M} \mathrm{HCl}$ with various experimental techniques like weight loss, electrochemical impedance spectroscopy (EIS), and potentiodynamic polarization techniques.

A three-component reaction of 5-aminopyrazole 16, arylaldehyde 47 and $N$-methyl-1-(methylthio)-2-nitroethenamine (96) was studied by Gunasekaran et al. [77] (Scheme 28) in ethanol in presence of $30 \mathrm{~mol} \% \mathrm{~L}$-proline as catalyst at $78^{\circ} \mathrm{C}$ which resulted in the production of pyrazolo[3,4-b]pyridine derivatives 97 in excellent yields.

Jiang et al. [78] have investigated a microwave-irradiated reaction of 5-aminopyrazoles 16, 2,2-dihydroxy-1-phenylethanone (98) and $p$-toluidine (99) under various polar and non-polar solvents with bronsted and lewis acid catalysts (Scheme 29). The reaction in dimethylformamide in presence of $p$-TSA resulted in the formation of azepino[5,4,3-cd] indole $\mathbf{1 0 0}$ instead of expected pyrazolo[3,4-b]pyridine derivatives 101. However, the reactions of arylglyoxal $\mathbf{9 8}$ having an electron-donating group at $\mathrm{C}-4$ position of the phenyl ring resulted in the formation of the desired pyrazolo[3,4-b]pyridines 101.

Wang et al. [79] studied the base-catalyzed multicomponent domino reaction of 5-aminopyrazoles 16, cyclic 1,3-diones 58 and arylglyoxals 98 under microwave irradiation. Triethylamine $(20 \mathrm{~mol} \%)$ as base and DMSO as solvent at $120{ }^{\circ} \mathrm{C}$ provided best results with high yields of pyrazolo[3,4-e]indolizines (a derivative of pyrazolo[3,4-b]pyridines) 102 (Scheme 30).

\section{Synthesis of pyrazolo[1,5-a]pyrimidines}

Pyrazolo[1,5-a]pyrimidines, structural isomers of pyrazolo[3,4b]pyridines, are of interest because they constitute an important class of heterocycles which display biological and pharmaco-

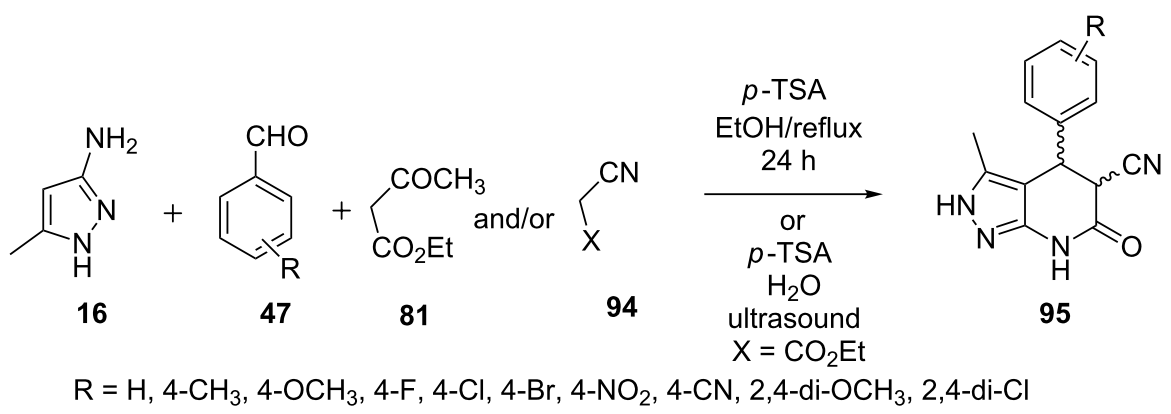




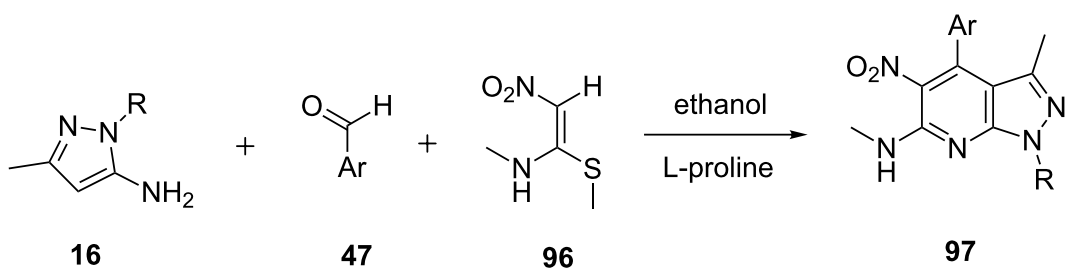

$\mathrm{R}=\mathrm{Ph}, 4-\mathrm{Cl}-\mathrm{Ph}, 4-\mathrm{Br}-\mathrm{Ph}, 4-\mathrm{F}-\mathrm{Ph}, 4-\mathrm{OMe}$

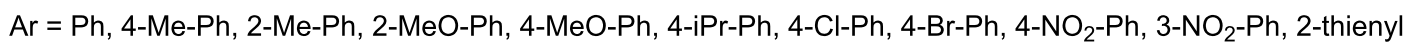

Scheme 28: L-Proline-catalyzed synthesis of of pyrazolo[3,4-b]pyridine.<smiles>[R]c1cc(N)n([R])n1</smiles>

16

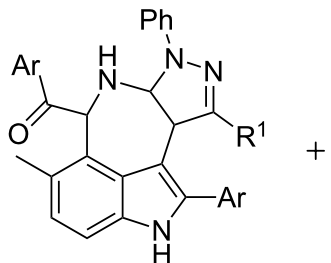

100

$\mathrm{R}^{3}=\mathrm{Me} \quad \mathrm{Ar}=\mathrm{Ph}$<smiles>[R]Nc1nc([Al])nc(Nc2ccc([R])cc2)c1C(=O)[Al]</smiles>

101

$\mathrm{R}^{3}=\mathrm{MeO}, \mathrm{Cl}, \mathrm{Br}$

$\mathrm{Ar}=\mathrm{Ph}, 4-\mathrm{Me}-\mathrm{Ph}, 4-\mathrm{MeO}-\mathrm{Ph}, 4-\mathrm{Cl}-\mathrm{Ph}, 4-\mathrm{Br}-\mathrm{Ph}, 4-\mathrm{NO}_{2}-\mathrm{Ph}$

$\mathrm{R}^{1}=\mathrm{Me}$, cyclopropyl $\quad \mathrm{R}^{2}=\mathrm{Me}, \mathrm{Ph} \quad \mathrm{R}^{3}=\mathrm{Me}, \mathrm{MeO}, \mathrm{Cl}, \mathrm{Br}$

Scheme 29: Microwave-assisted synthesis of 5-aminoarylpyrazolo[3,4-b]pyridines.

logical activities and are useful precursors in the synthesis of many biologically active compounds [80-83]. Consequently, there has been an ongoing interest in the synthesis of pyrazolo[1,5-a]pyrimidines [84-86].

Navarrete et al. [87] reported the reaction of acetylacetone (104) with 5-amino-3-(4-iodophenyl)pyrazole $\mathbf{1 0 3}$ in ethanol that gives pyrazolo[1,5-a]pyrimidine derivatives $\mathbf{1 0 5}$ which were subsequently used to prepare alkynyl alcohol $\mathbf{1 1 1}$ derivatives of pyrazolo[1,5- $a$ ]pyrimidines $\mathbf{1 0 6}$ by a Sonogashira coupling in 69-94\% yields. Fluorodeoxygention of 106 using deoxofluor afforded fluoropropynyl-substituted pyrazolo[1,5- $a$ ]pyrimidine 107 with variable efficiency in terms of yields. Alternatively, by shuffling the steps of acetylacetone condensation and fluoroalkynylation, via 5-amino-3-(4-(fluoroalkynyl)phenyl)pyrazole 108 intermediate, a better and efficient route to synthesize 107 was developed (Scheme 31). Recently, the same research group [19] also reported the synthesis of fluoroalkyl-substituted 


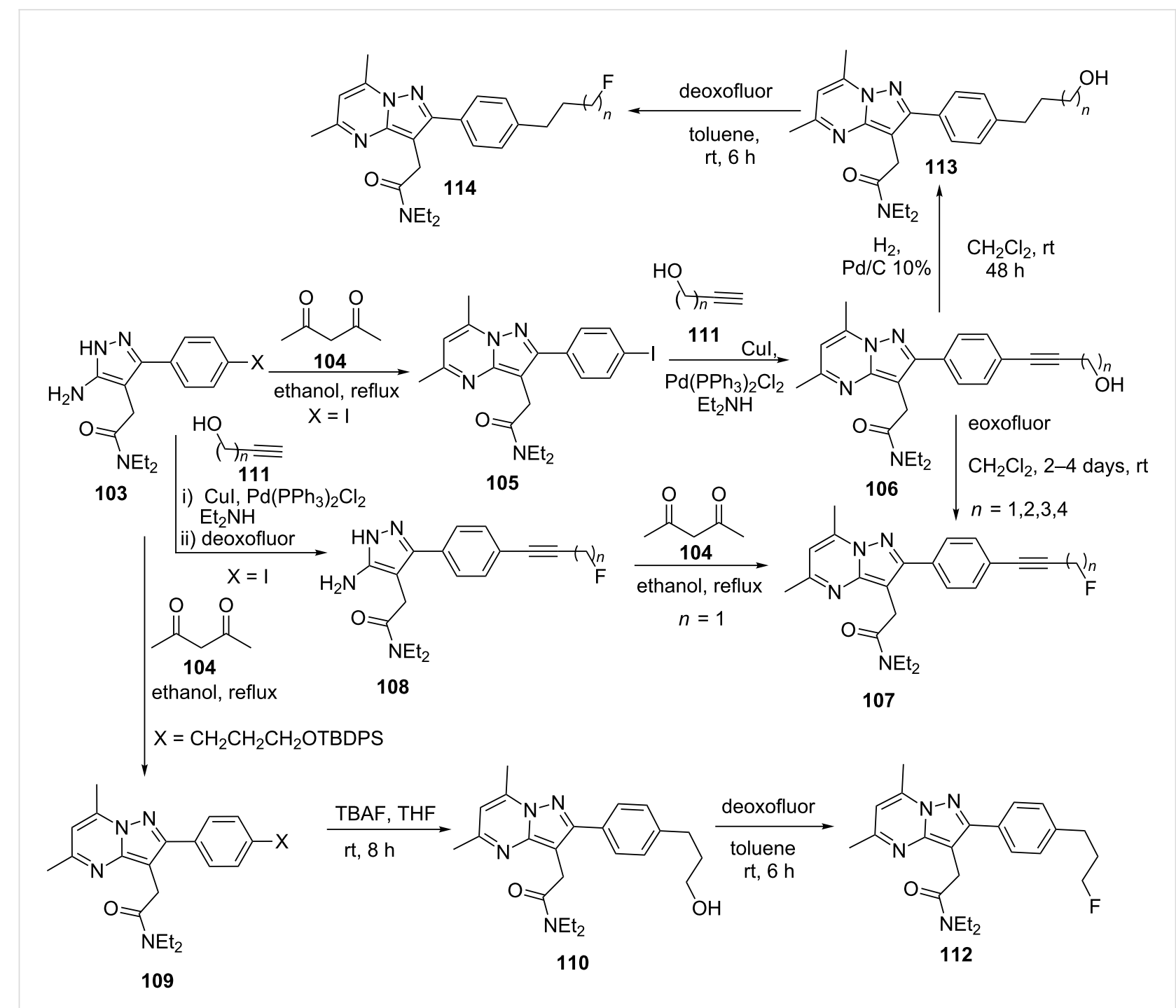

Scheme 31: Synthesis of fluoropropynyl and fluoroalkyl substituted pyrazolo[1,5-a]pyrimidine

pyrazolo[1,5- $a$ ]pyrimidine derivatives 112 and 114 using similar synthetic strategies (Scheme 31). Alkynyl alcohol derivatives of pyrazolo[1,5- $a$ ]pyrimidines $\mathbf{1 0 6}$ were hydrogenated to give alkyl alcohol-substituted pyrazolo[1,5-a]pyrimidines 113 which on treatment with deoxofluor resulted in the formation of fluoroalkyl-pyrazolo[1,5-a]pyrimidines 114. Additionally, reaction of $\mathbf{1 0 4}$ with $\mathbf{1 0 3}$ in refluxing ethanol resulted in the formation of pyrazolo[1,5-a]pyrimidines $\mathbf{1 0 9}$ which on treatment with TBAF provided alkyl alcohol derivatives of pyrazolo[1,5a]pyrimidines 110 which were later on converted to fluoroalkyl pyrazolo[1,5-a]pyrimidines $\mathbf{1 1 2}$ by treatment with deoxofluor.

Marjani et al. [88] have described the synthesis of pyrazolo[1,5a]pyrimidine 116 and 4,7-dihydropyrazolo[1,5-a]pyrimidinone derivatives 117 by condensing 4-cyano/carboxylate-5-aminopyrazole derivatives 115 with acetylacetone (104) and various $\beta$-ketoesters 81, respectively, in refluxing acetic acid with catalytic amount of suphuric acid (Scheme 32).

The reaction of 3(5)-amino-5(3)-hydrazinopyrazole dihydrochloride (118) with symmetrical and unsymmetrical diketones 119 was studied by Aggarwal et al. [80,89] under aqueous conditions. The reaction exhibited a high level of chemoselectivity and regiospecificity yielding 2-(3methylpyrazol-1-yl)-5-methylpyrazolo[1,5-a]pyrimidines $\mathbf{1 2 0}$ out of the four possible isomers (Scheme 33). In the case of arylbutadiones, formation of two more products in small amounts namely 3(5)-methyl-5(3)-phenyl- $1 H$-pyrazole (121) obtained by $\mathrm{CN}$ bond cleavage and benzoic acid (122) was also observed (Scheme 33). The structure of the regioisomer was established unequivocally by performing ${ }^{1} \mathrm{H},{ }^{13} \mathrm{C}-\mathrm{HMQC}$, ${ }^{1} \mathrm{H},{ }^{13} \mathrm{C}$ - and ${ }^{1} \mathrm{H},{ }^{15} \mathrm{~N}-\mathrm{HMBC}$ experiments. Aqueous mediated 


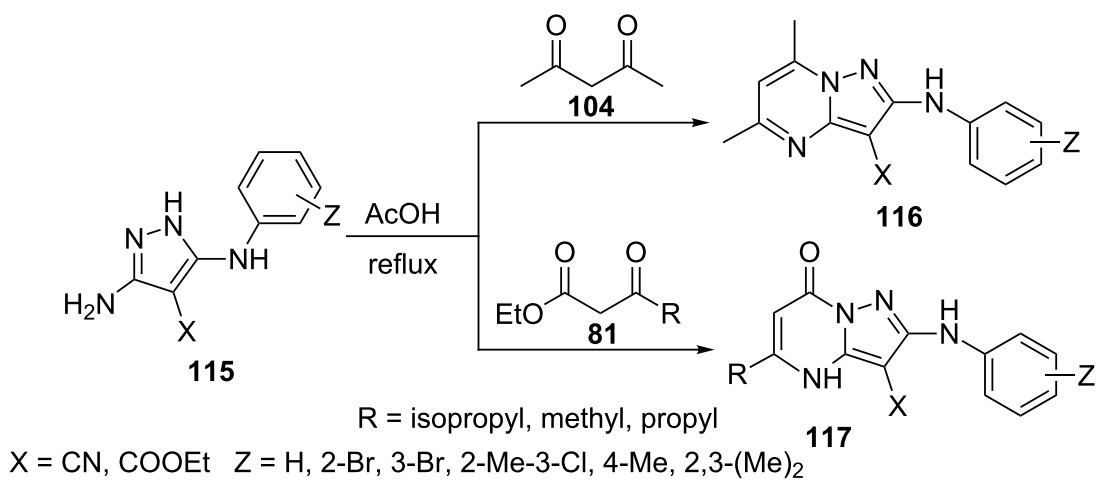

Scheme 32: Acid-catalyzed synthesis of pyrazolo[1,5-a]pyrimidine derivatives.

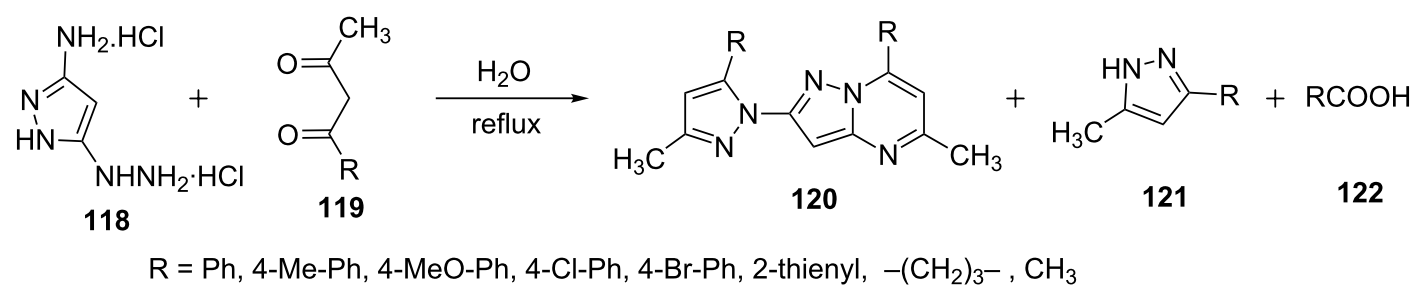

Scheme 33: Chemoselective and regiospecific synthesis of 2-(3-methylpyrazol-1'-yl)-5-methylpyrazolo[1,5-a]pyrimidines.

conditions makes it a sought after the procedure for the synthesis of pyrazolo[1,5- $a]$ pyrimidines.

In another report, Aggarwal et al. [90] have described a regioselective synthesis of 2- $H$ /methyl-3-phenyl-7-trifluoromethylpyrazolo[1,5- $a$ ]pyrimidines 124 by condensing 4-aryl-5-aminopyrazoles $\mathbf{1 2 3}$ with an equimolar amount of trifluoromethyl- $\beta$-diketones 17. To gain an insight of the reaction mechanism, the intermediate, 5-methyl-3-phenyl-7-trifluoromethyl-4,5,6,7tetrahydropyrazolo[1,5-a]pyrimidine-5,7-diol 125 was isolated by performing the reaction in DCM at $-15^{\circ} \mathrm{C}$ for $6 \mathrm{~h}$ which was later converted to 7-trifluoromethylpyrazolo[1,5-a]pyrimidine derivative 124 by dehydration on refluxing with acetic anhydride (Scheme 34). All the synthesized compounds were screened for their anti-inflammatory activity.

Mulakayala and co-workers [91] synthesized 7-trifluoromethylpyrazolo[1,5-a]pyrimidine carboxylates 127 by the reaction of 5-aminopyrazole-4/3-ethylcarboxylates $\mathbf{1 2 6}$ with trifluoromethyl- $\beta$-diketones $\mathbf{1 7}$ in acetic acid under microwave heating, which were subsequently hydrolyzed to the corresponding pyrazolo[1,5- $a$ ]pyrimidine carboxylic acids $\mathbf{1 2 8}$ by treating with<smiles>[R]C(=O)CC(=O)C(F)(F)F</smiles>

17<smiles>[R]c1[nH]nc(N)c1-c1ccccc1</smiles>

123<smiles>CCCCCCOCC</smiles>

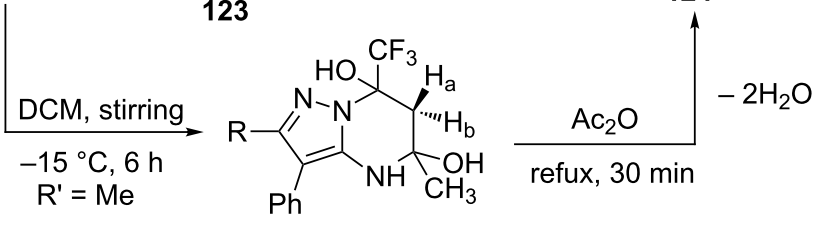<smiles>[R]c1cc(C(F)(F)F)n2nc([R])c(-c3ccccc3)c2n1</smiles>

124

125 
sodium hydroxide in ethanol at $65{ }^{\circ} \mathrm{C}$. The compounds were screened for their cytotoxic activity against human colon carcinoma (Colo-205) cell lines (Scheme 35).

Buriol et al. [92] described the reaction of 5-aminopyrazole 16 with 4-alkoxy-1,1,1-trifluoro-3-alken-2-ones 129 to yield pyrazolo[1,5-a]pyrimidine derivatives $\mathbf{1 3 0}$ in acetic acid and ethanol using conventional heating, ultrasound and microwave conditions (Scheme 36). The reaction in ethanol provided best results with high yields of pyrazolo[1,5-a]pyrimidines $\mathbf{1 3 0}$. The effect of microwave irradiation was found to be as efficient as of ultrasound radiations with better yields and shorter reaction times than conventional heating methods.

Recently, Boruah et al. [93] reported an unprecedented synthesis of pyrazolo[1,5-a]pyrimidines $\mathbf{1 3 2}$ involving a $\mathrm{C}-\mathrm{C}$ bond cleavage through $\mathrm{KO} t$-Bu-catalyzed condensation of 1,3,5trisubstituted pentane-1,5-diones $\mathbf{1 3 1}$ with substituted 5-amino- pyrazoles 16 in ethanol. Symmetrical 1,5-dicarbonyls reacted efficiently with 5 -aminopyrazoles $\mathbf{1 6}$ to give the corresponding substituted pyrazolo[1,5-a]pyrimidines 132 (Scheme 37). Moreover, the reaction of 1,5-dicarbonyls 131 with 5-amino-3methylpyrazole 16 provided a mixture of two regioisomeric pyrazolo[1,5-a]pyrimidines.

Kamal et al. [94] reported the synthesis of aminobenzothiazole linked pyrazolo[1,5-a]pyrimidine conjugates (benzothiazolyl derivatives, 136). Methyl-2,7-diphenylpyrazolo[1,5-a]pyrimidine-5-carboxylates, obtained by the reactions of 5-aminopyrazole 16 with aryl- $\beta$-diketoesters $\mathbf{1 3 3}$ in ethanol, were hydrolyzed in presence of methanolic sodium hydroxide to give corresponding carboxylic acids 134. Aminobenzothiazoles 135 were linked with carboxylic acids $\mathbf{1 3 4}$ to provide the amide derivatives (benzothiazolyl derivatives, 136) using amide coupling reagent 1-ethyl-3-(3-dimethylaminopropyl)carbodiimide-hydroxybenzotriazole (Scheme 38 ). The compounds

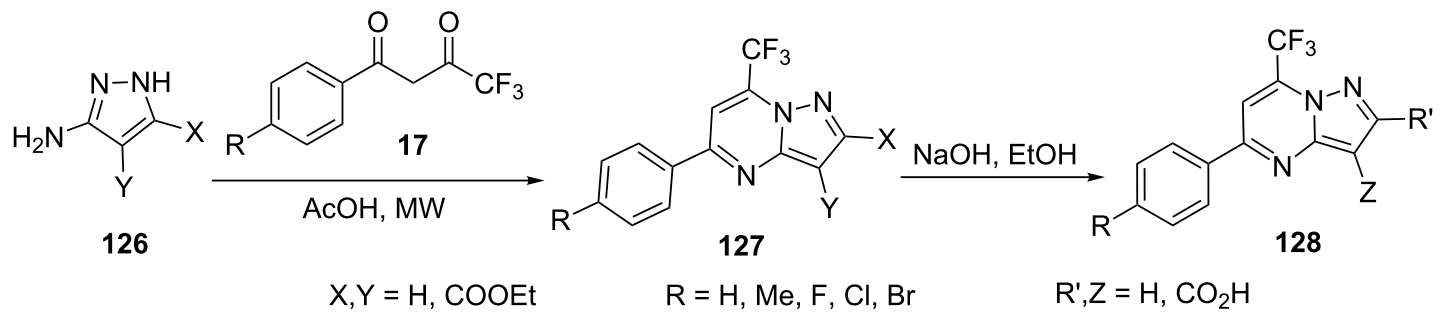

Scheme 35: Microwave-assisted synthesis of 7-trifluoromethylpyrazolo[1,5-a]pyrimidine carboxylates.<smiles>[R14]C(=CC(=O)C(=O)OCC)OC([R])=CC(=O)C(F)(F)F</smiles>

$\mathrm{R}=\mathrm{Me}, \mathrm{Bu}, \mathrm{iBu}, \mathrm{Ph}, 4-\mathrm{Me}-\mathrm{Ph}, 4-\mathrm{F}-\mathrm{Ph}, 4-\mathrm{Cl}-\mathrm{Ph}, 4-\mathrm{Br}-\mathrm{Ph}$, naphth-2-yl, biphenyl-4-yl

Scheme 36: Microwave and ultrasound-assisted synthesis of 7-trifluoromethylpyrazolo[1,5-a]pyrimidines.

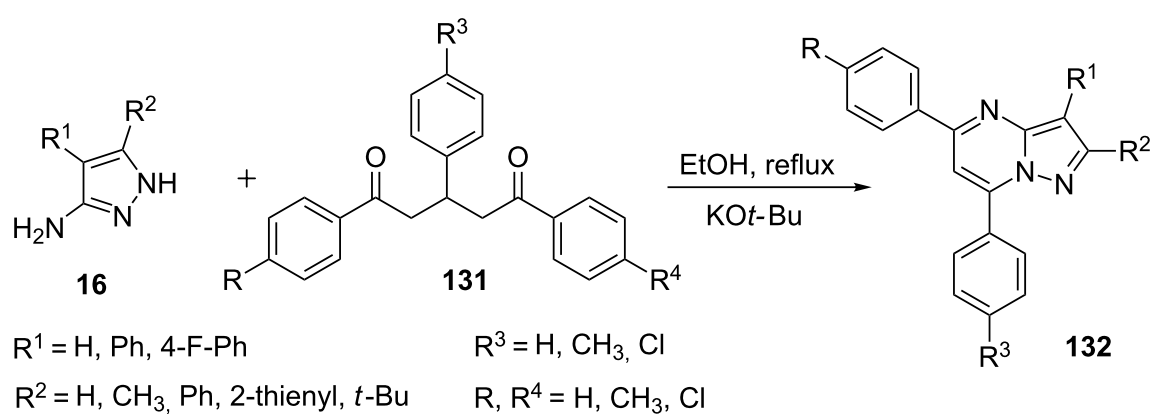


<smiles>Nc1cc(-c2ccccc2)[nH]n1</smiles>

i)<smiles>[R]c1cc(C(=O)CC(=O)C(=O)OC)cc([R])c1[R]</smiles>

EtOH, $\mathrm{H}^{+} / \mathrm{HCl}$, reflux

ii) $2 \mathrm{~N} \mathrm{NaOH}, \mathrm{MeOH}$

16

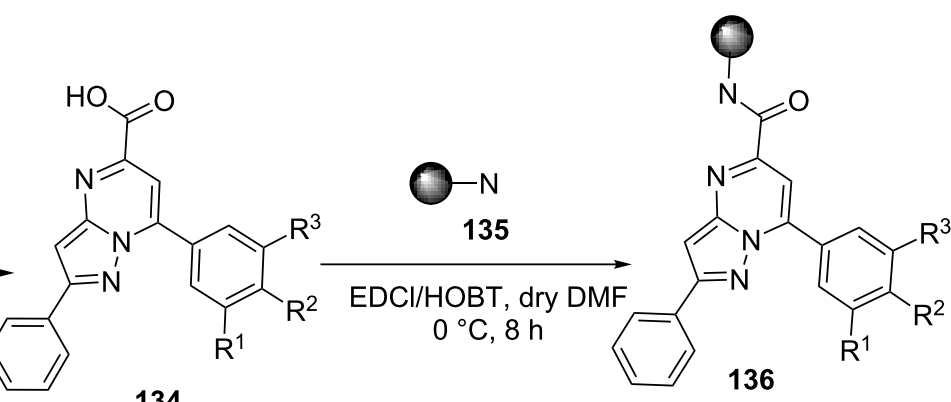

134
136

$\mathrm{R}^{1}=\mathrm{H}, \mathrm{OCH}_{3} \quad \mathrm{R}^{2}=\mathrm{F}, \mathrm{Cl}, \mathrm{OCH}_{3} \quad \mathrm{R}^{3}=\mathrm{H}, \mathrm{Cl}, \mathrm{OCH}_{3} \quad-\mathrm{N}=$ benzothiazolyl and piperazinyl derivatives

Scheme 38: Synthesis of aminobenzothiazole/piperazine linked pyrazolo[1,5-a]pyrimidines.

were found to possess good anticancer activity against human colon, leukemia, melanoma cancer cell lines. In another report, Kamal et al. [95] synthesized similar pyrazolo[1,5-a]pyrimidinyl amide derivatives (piperazinyl derivatives, 136) by condensing piperazin-1-yl(pyridin-3-yl)methanone (piperazinyl derivatives, 135) with $\mathbf{1 3 4}$ which were evaluated for their cytotoxic potential against MCF-7, HeLa, IMR 32 and SiHa cancer cell lines. Pyrazolo[1,5- $a$ ]pyrimidinyl amide derivatives $\mathbf{1 3 6}$ having piperazinyl derivatives, $\mathrm{R}^{1}=\mathrm{H}, \mathrm{R}^{2}=\mathrm{F}$ and $\mathrm{OCH}_{3}, \mathrm{R}^{3}=$ $\mathrm{H}$ and $\mathrm{OCH}_{3}$, respectively, were found to be the most active compounds showing a minimum survival of the cancer cells.

Griffith et al. [96] described the synthesis of 7-hydroxypyrazolo[1,5- $a$ ]pyrimidine derivatives $\mathbf{1 3 7}$ by cyclocondensation of 5-aminopyrazole $126(\mathrm{X}=\mathrm{Me}, \mathrm{Y}=\mathrm{Ar})$ with ethyl acetoacetate 81. Pyrazolo[1,5-a]pyrimidine derivatives $\mathbf{1 3 7}$ thus obtained were treated with $\mathrm{POCl}_{3}$ to give the 7-chloropyrazolo[1,5a]pyrimidine derivative which on coupling with the appropriately substituted diamine derivatives provided aminoalkylpyrazolo[1,5-a]pyrimidine-7-amines 139. Substituted ethylenediamines resulted in the product formed by addition from the less sterically hindered amino group. The free amino group was alkylated by reductive amination on reaction with substituted aldehyde or ketones to provide the corresponding pyrazolo[1,5a]pyrimidine derivatives 139 (Scheme 39). The pyrazolo[1,5a]pyrimidine derivatives $\mathbf{1 3 9}$ were evaluated as neuropeptide NPY Y1R antagonists with high binding affinity and selectivity.

Using a similar approach Dwyer et al. [97] reported the synthesis of various pyrazolo[1,5-a]pyrimidinyl derivatives 142,143 , 145 and 146 following a sequence of reactions as depicted in Scheme 40 and Scheme 41. 7-Chloropyrazolo[1,5-a]pyrimidines 140 obtained by 4-H/cyano/carboxylate-5-aminopyrazoles $126(\mathrm{X}=\mathrm{H}, \mathrm{Y}=\mathrm{R})$ and $\beta$-ketoesters $\mathbf{8 1}$ followed by chlorination with $\mathrm{POCl}_{3}$, were converted to 7-aminopyrazolo[1,5- $a$ ]pyrimidines 142 and 7-methoxy/thiomethoxypyrazolo[1,5-a]pyrimidines 143 on treatment of NIS, $\mathrm{NH}_{3} 141$ in propanol and $\mathrm{NaOMe} / \mathrm{NaSMe}$ in THF, respectively. Further, compound 143 was coupled with 3-pyrazolylboronate to give 3-pyrazolylpyrazolo[1,5-a]pyrimidines 145 and subsequently converted to 7-amino-3-pyrazolylpyrazolo[1,5-a]pyrimidines 146 (Scheme 41). The synthesized pyrazolo[1,5-a]pyrimidine derivatives were evaluated for their CHK1 kinase inhibitory activity. Pyrazolo[1,5-a]pyrimidine derivative 142 with $\mathrm{R}^{1}=3$-(1-

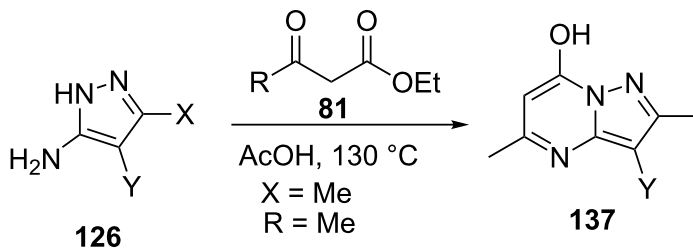

$\mathrm{Y}=$ 2,4,6-Me-Ph, 2,6-Cl-Ph, 2,6-Cl-4-MeO-Ph, 2,6-Cl-4-EtO-Ph, 2,6-Cl-4-n-PrO-Ph
I) $\mathrm{POCl}_{3}, 130^{\circ} \mathrm{C}$

II) $\mathrm{R}_{\mathrm{R}_{1}^{1} \mathrm{R}^{2}}^{\mathrm{H}_{138} \mathrm{~N}} \mathrm{NH}_{2}, \mathrm{CH}_{3} \mathrm{CN}$

III) aldehyde or ketone $\mathrm{NaBH}(\mathrm{OAC})_{3}, \mathrm{AcOH}, \mathrm{rt}$<smiles>[R]NC([R])([R])CNc1cc(C)nc2c([Y])c(C)nn12</smiles>

$R^{1}, R^{2}=H, M e$

$\mathrm{R}^{\prime}=\mathrm{H}, \mathrm{CH}_{2} \mathrm{CH}_{2} \mathrm{~F}, \mathrm{CH}_{2} \mathrm{CHF}_{2}, \mathrm{CH}_{2} \mathrm{CH}_{2}-4-\mathrm{MeO}-\mathrm{Ph}$, cyclopentyl, 4-THP, 2-F-cyclohex-1-yl 


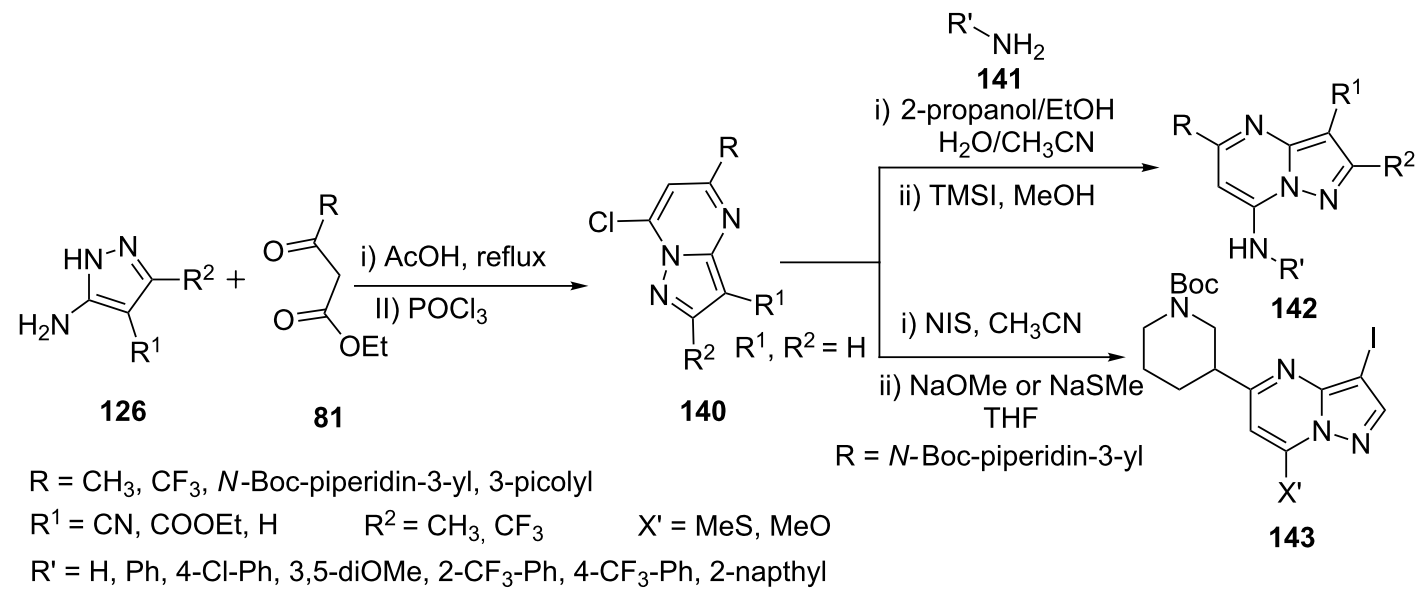

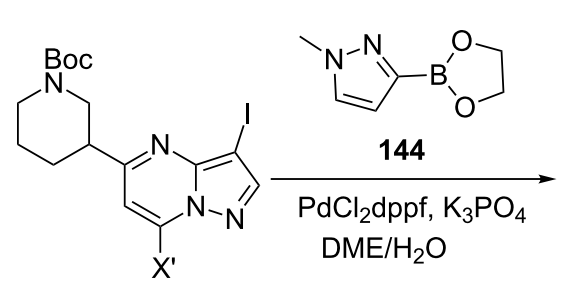

143<smiles>[X]c1cc(C2CCC[N+](NN)(C(=O)OCc3ccccc3)O2)nc2c(-c3cnn(C)c3)cnn12</smiles>

145<smiles>[R]Nc1cc(C2CCCNC2)nc2c(-c3cnn(C)c3)cnn12</smiles>

146

$X^{\prime}=$ OMe, SMe $\quad R^{\prime}=H$, alkyl, aryl, heteroaryl

Scheme 41: Synthesis of 7-aminopyrazolo[1,5-a]pyrimidines.

methylpyrazolyl), $\mathrm{R}^{2}=\mathrm{H}, \mathrm{R}=3$-pyridyl and $\mathrm{R}^{\prime}=5$-(3-methylthiazolyl) was found to be the most potent, selective CHK1 inhibitor.

Azeredo et al. [98] reported a similar synthesis of 7 -arylaminopyrazolo[1,5-a]pyrimidines 143 by the coupling reaction of 7-chloropyrazolo[1,5-a]pyrimidines $\mathbf{1 4 0}$ with various aryl amines 141 in ethanol, which were evaluated for their anti-Plasmodium falciparum, antimalarial, and Pf-dihydroorotate dehydrogenase inhibitory activity (Scheme 40). 7-Arylaminopyrazolo[1,5-a]pyrimidine derivative 142 with $\mathrm{R}=\mathrm{CF}_{3}, \mathrm{R}^{1}=\mathrm{H}, \mathrm{R}^{2}=\mathrm{CH}_{3}$ and $\mathrm{R}^{\prime}=7-\beta$-naphthyl was found to be having highest selectivity and inhibition with $\mathrm{IC}_{50}=$ $0.16 \pm 0.01 \mathrm{mM}$.

Synthesis of 7-aminopyrazolo[1,5-a]pyrimidines $\mathbf{1 4 6}$ was also reported by Hylsov et al. [99] using an almost similar synthetic procedure by coupling 7-chloropyrazolo[1,5-a]pyrimidines 140 with 3-picolylamine in acetonitrile at reflux temperature (Scheme 40).
Recently, Aggarwal et al. [100] reported an unexpected synthesis of 7-aminopyrazolo $[1,5-a]$ pyrimidine $\left(\mathrm{R}^{\prime}=\mathrm{R}, 148\right)$ from the reaction of 3(5)-amino-5(3)-hydrazinopyrazole dihydrochloride (147) with 3-oxo-3-arylpropanenitrile 15 under solvent-free grinding conditions. The reaction was proposed to proceed via formation of hydrazine by $\mathrm{C}-\mathrm{N}$ bond cleavage which under reaction conditions provided 7-aminopyrazolo[1,5-a]pyrimidines 148 on coupling with 3-oxo-3-arylpropanenitrile 15 (Scheme 42). The structure of compounds 148 was established by the combined use of NMR and DFT calculations.

In another report Aggarwal et al. [101] synthesized similar 7-aminopyrazolo[1,5-a]pyrimidine $\mathbf{1 4 8}$ from the reaction of hydrazine hydrate with two different 3-oxo-3-arylpropanenitriles 15 which are successively added one after the other in toluene/ethanol (9:1) at reflux temperature in presence of $p$-TSA. The reaction carried out in pure ethanol provided a mixture of 5-aminopyrazoles (Scheme 42). The synthesized 7-aminopyrazolo[1,5-a]pyrimidines 148 were found to be good anti-inflammatory agents. 


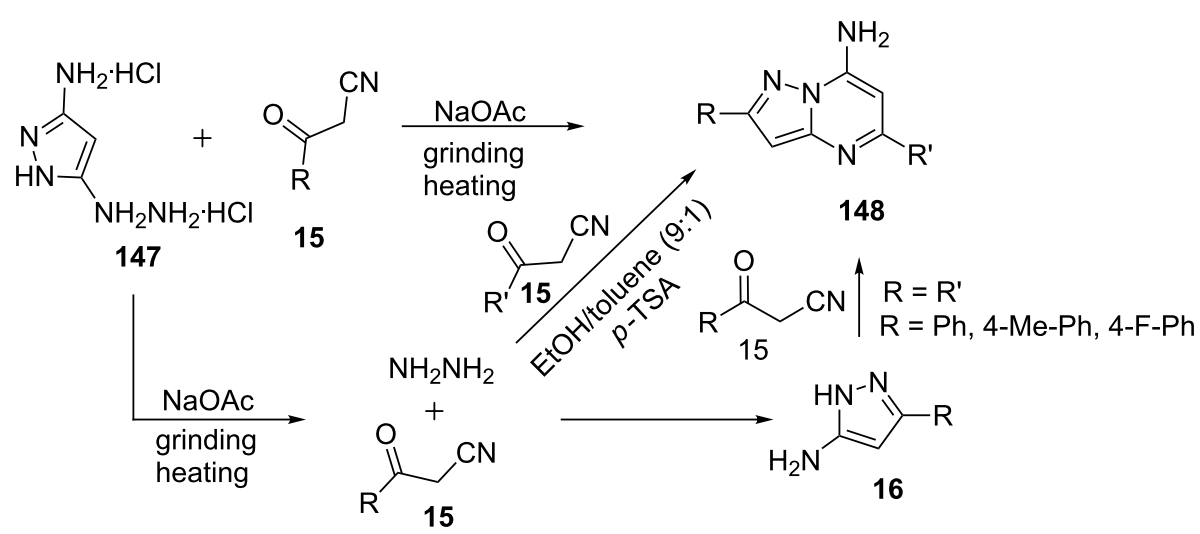

$\mathrm{R}^{\prime}, \mathrm{R}=\mathrm{Ph}, 4-\mathrm{Me}-\mathrm{Ph}, 4-\mathrm{F}-\mathrm{Ph}, 4-\mathrm{Cl}-\mathrm{Ph}, 4-\mathrm{Br}-\mathrm{Ph}$

Scheme 42: Unexpected synthesis of 7-aminopyrazolo[1,5-a]pyrimidines under solvent free and solvent-mediated conditions.

Tian et al. [102] reported a protocol for the efficient synthesis of pyrazolo[1,5- $a$ pyrimidine-5,7-dione $(\mathbf{1 5 0})$ by the reaction of 5-aminopyrazole (126) with diethyl malonate (149). Pyrazolo[1,5-a]pyrimidine-5,7-dione (150) was chlorinated to give 5,7-dichloropyrazolo[1,5-a]pyrimidine (151) which subsequently coupled with various phenols $\mathbf{1 5 2}$ at the more reactive 7-position under mild reaction conditions in presence of $\mathrm{K}_{2} \mathrm{CO}_{3}$ in acetic acid/DMF to give pyrazolo[1,5- $a$ ]pyrimidine derivative 153. Various aromatic amines $\mathbf{1 5 4}$ were then coupled at 5 -postion under Buchwald-Hartwig conditions to get the desired 5-aminopyrazolo[1,5-a]pyrimidine derivatives $\mathbf{1 5 5}$ (Scheme 43). All the synthesized compounds were screened for their anti-HIV activities in MT4 cell cultures and compound $155\left(R^{1}=2,4,6\right.$-trimethyl and $R^{2}=4$-cyano) was found as most inhibiting for HIV-1 replication having an $\mathrm{EC}_{50}=0.070 \mu \mathrm{M}$ and the SI (selectivity index) $=3999$, which were better than the drugs NVP (nevirapine) $\left(\mathrm{EC}_{50}=0.17 \mu \mathrm{M}\right)$ and DLV (delavirdine) $\left(\mathrm{EC}_{50}=0.16 \mu \mathrm{M}\right)$.

Kaswan et al. [103] reported the reaction of 5-aminopyrazoles $\mathbf{1 6} / \mathbf{1 2 6}$ with chalcones 156 in DMF in the presence of inorganic base $\mathrm{KOH}$ for the synthesis of 5,7-diarylpyrazolo[1,5a]pyrimidines 157. Chalcones 156 with electron-withdrawing group like nitro, cyano on para-position of aryl or heteroaryl ring and 2-hydroxyphenyl group resulted in lower yields as compared to chalcones with electron-donating groups (Scheme 44).

Chobe et al. [104] reported the reaction of 3,5-diamino-4diazopyrazole derivative $\mathbf{1 5 8}$ with 4-substituted benzylidene-3-

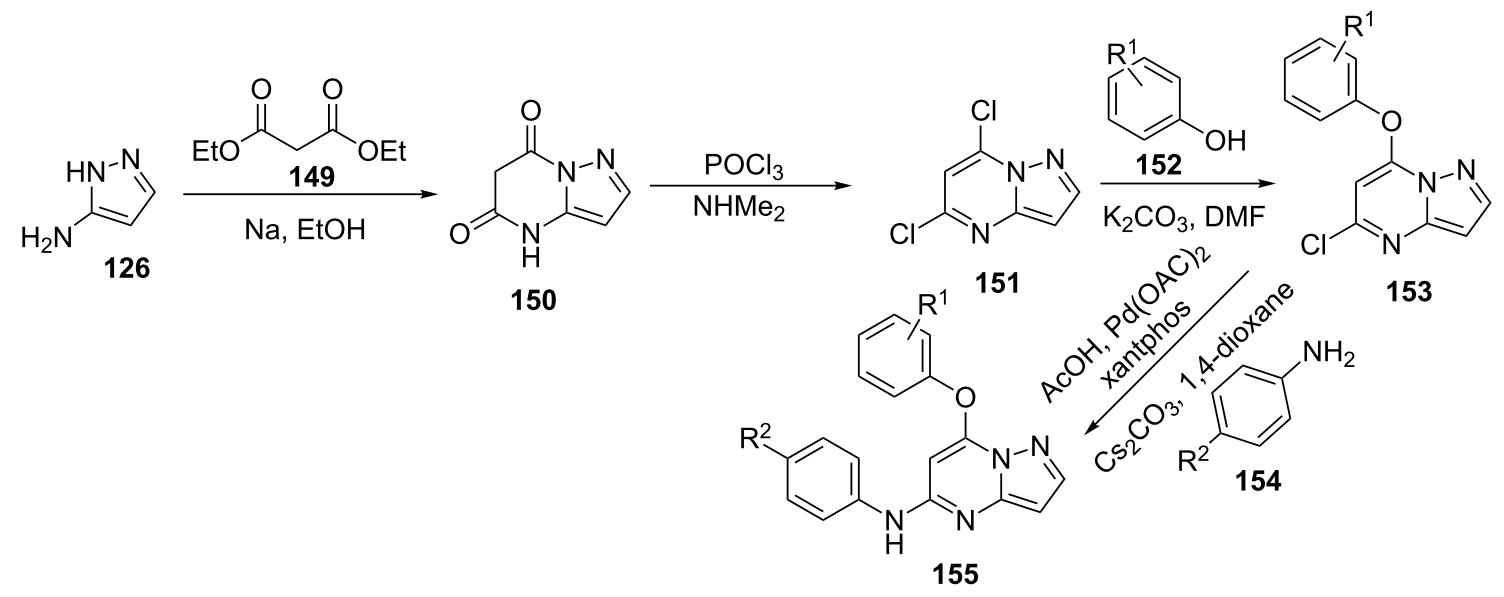

$\mathrm{R}^{1}$ = 2,6-dimethyl, 3,5-dimethyl, 2,6-dimethyl-4-bromo, 2,6-dimethyl-4-cyano, 2,4,6-trimethyl, 2,4,6-trifluoro

$\mathrm{R}^{2}=\mathrm{F}, \mathrm{Cl}, \mathrm{Br}, \mathrm{CH}_{3}, \mathrm{OCH}_{3}, \mathrm{CN}, \mathrm{NO}_{2}$ 


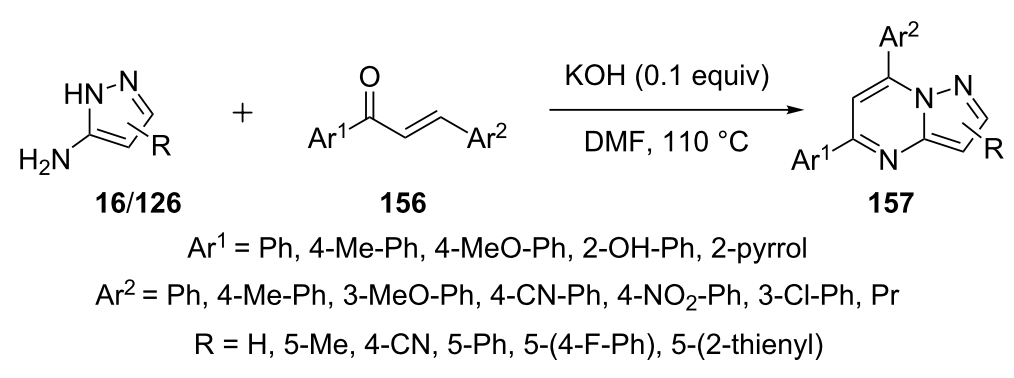

Scheme 44: Base-catalyzed synthesis of 5,7-diarylpyrazolo[1,5-a]pyrimidines.

methyl-1H-pyrazol-5(4H)-one 159 in PEG-400. The reaction resulted in the synthesis of 6,7-dihydropyrazolo[1,5- $a$ ]pyrimidine derivatives 160 (Scheme 45). Selected compounds were studied for their interaction with calf thymus DNA using various techniques like electronic spectra, viscosity measurement and thermal denaturation.

Ahmetaj et al. [105] described a simple and efficient protocol for the synthesis of 7-heteroarylpyrazolo[1,5-a]pyrimidine-3carboxamides 166 from the reaction of 5-aminopyrazole 161 with (E)-3-(dimethylamino)-1-(heteroaryl)prop-2-en-1-one $\mathbf{1 6 2}$ in aqueous ethanol at ambient temperature through the intermediacy of methyl 7-heteroarylpyrazolo[1,5-a]pyrimidine-3carboxylates 163 which was subsequently hydrolyzed to give the corresponding carboxylic acids $\mathbf{1 6 4}$ followed by coupling with various primary and secondary amines $\mathbf{1 6 5}$ in presence of bis(pentafluorophenyl) carbonate (BPC) as activating agent (Scheme 46).

Abdelhamid et al. [106] reported the synthesis of pyrazolo[1,5a]pyrimidine derivatives $\mathbf{1 6 8}$ from the reaction of 5-aminopyrazoles 16/126 with sodium 3-(5-methyl-1-phenyl-1H-pyrazol-4yl)-3-oxoprop-1-en-1-olate (167) with high regioselectivity without any traces of other possible regioisomeric pyrazolo[1,5a]pyrimidines 169. The regioselectivity of the reaction was attributed to the higher nucleophilicity of the exocyclic primary amino group over the endocyclic amino group. Synthesis of pyrazolo[1,5-a]pyrimidine derivatives 168 was also achieved by an alternate route with equal ease by the reaction of 5 -aminopyrazoles 16/126 with 3-(dimethylamino)-1-(5-methyl-1-phenyl-1H-pyrazol-4-yl)prop-2-en-1-ones (170) for structural confirmations (Scheme 47).

Recently, Abdelhamid et al. [107] also reported the synthesis of 7-(furan-2-yl)-2-phenylpyrazolo[1,5-a]pyrimidine (168) using a similar synthetic strategy from the reaction of 5-aminopyrazole 16/126 with sodium 3-(furan-2-yl)-3-oxoprop-1-en-1-olate (167, Scheme 47).

Ren et al. [108] described the synthesis of 6-aminopyrazolo[1,5a]pyrimidine derivatives $\mathbf{1 7 2}$ involving the condensation of 5-aminopyrazole derivative $\mathbf{1 6}$ and sodium nitromalonaldehyde 171 followed by reduction of the nitro group by hydrogenation to give 6-aminopyrazolo[1,5-a]pyrimidines 172. 6-Aminopyrazolo[1,5-a]pyrimidines $\mathbf{1 7 2}$ thus obtained were coupled with variously substituted benzoic acids $\mathbf{1 7 3}$ to give corresponding<smiles>Nc1n[nH]c(N)c1/N=N/c1ccc(Cl)cc1</smiles>

158<smiles>[R]C=C1C(=O)N(c2ccccc2)N=C1C</smiles>

159<smiles>[R]C1C2C(C)=NN(c3ccccc3)C2=Nc2c(/N=N/c3ccc(Cl)cc3)c(N)nn21</smiles>

160<smiles>[Y6]c1cn(-c2cccc(C=[R])c2)nc1-c1ccc(OC)cc1</smiles> 


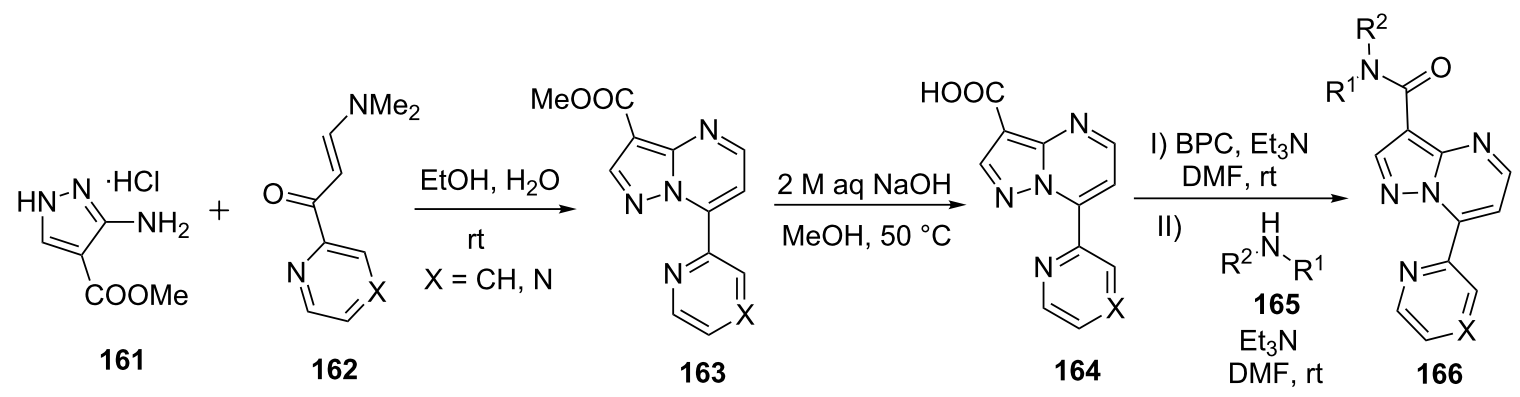

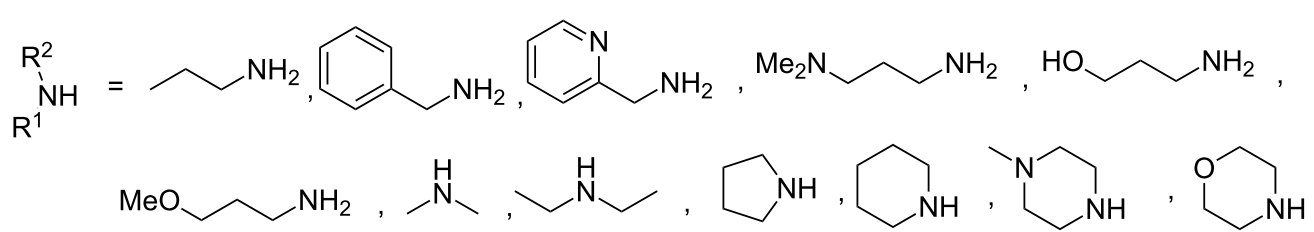

$\mathrm{BPC}=$ bis(pentafluorophenyl) carbonate<smiles>[X]c1[nH]nc(N)c1[R]</smiles>

$16 / 126$

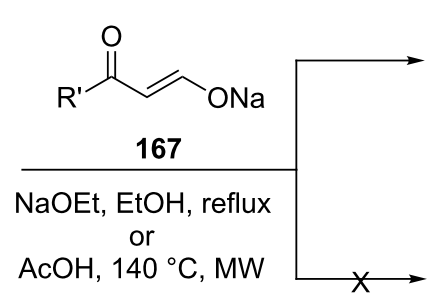

$\mathrm{R}=\mathrm{H}, \mathrm{CH}_{3}, \mathrm{C}_{6} \mathrm{H}_{5}$<smiles>[R]c1[nH]nc(N)c1[Y10]([H])([H])CC</smiles><smiles>[R]C(=O)/C=C/N(C)C</smiles><smiles>[X]c1nn2c([R])ccnc2c1[R]</smiles>

$\mathrm{X}=\mathrm{H}, \mathrm{CN}, \mathrm{CH}_{3}$<smiles>[R]n1nc[Y](=C2C=CI(F)O2)c1C</smiles>

Scheme 47: Synthesis of 7-heteroarylpyrazolo[1,5-a]pyrimidine derivatives under conventional heating and microwave assistance.

amide derivatives of pyrazolo[1,5-a]pyrimidines 174 (Scheme 48). Some of the compounds were found to be potent, selective and orally available B-Raf inhibitors with favorable physicochemical and pharmacokinetic properties.

Stepaniuk et al. [109] reported the reaction of 5-aminopyrazole derivatives $\mathbf{1 6 / 1 2 6}$ with $\beta, \gamma$-unsaturated- $\gamma$-alkoxy- $\alpha$-ketoesters 175 for the regioselective synthesis of pyrazolo[1,5-a]pyrimidines 177 in refluxing ethanol. The reaction provided high regioselectivity compared to other 1,3-dielectrophiles like 1,3dicarbonyl compounds. The reaction was proposed to proceed through intermediate 176 which was isolated at $-10{ }^{\circ} \mathrm{C}$ to $0{ }^{\circ} \mathrm{C}$ but was found to be unstable even at room temperature (Scheme 49).
Ma et al. [110] reported the synthesis of 3-cyano-6,7diarylpyrazolo[1,5-a]pyrimidines 179 comprising the reaction of 1.5 equivalents of 5-aminopyrazole $\mathbf{1 2 6}$ with 1 equivalent of isoflavones $\mathbf{1 7 8}$ in the presence of 3 equivalents of sodium methoxide in methanol (Scheme 50). The method has the merits of being simple in operation with mild reaction conditions and good yields of fused pyrazole derivatives.

\section{Synthesis of pyrazolo[3,4- $d$ pyrimidines}

A diversity of biological effects is associated with pyrazolo[3,4$d]$ pyrimidines. They are known to exhibit antiviral [111,112], pesticidal [113], anti-inflammatory [114], antimicrobial [115117], antileukemic [118], antitumor [114,119,120], pan-RAF inhibiting [121], tyrosine kinase RET inhibiting [122], CNS 
<smiles>[R]c1cc(N)n[nH]1</smiles>

16<smiles>[R]c1cc2ncc(N)cn2n1</smiles>

173

$\mathrm{R}=\mathrm{Me}, \mathrm{Et}$, cyclopropyl, cyclopentyl, $\mathrm{CF}_{3}, \mathrm{OMe}, \mathrm{O}-\mathrm{iPr}, \mathrm{O}\left(\mathrm{CH}_{2}\right) \mathrm{OMe}, \mathrm{OEt}, \mathrm{NHCH}_{3}, \mathrm{NH}-\mathrm{iPr}$, pyrrolidin-1-yl, morpholino, $\mathrm{Ph}, 3-\mathrm{F}-\mathrm{Ph}, 4-\mathrm{F}-\mathrm{Ph}, 3-p y r i d i n y l, 1-M e-p y r a z o l-4-y l$

Scheme 48: Synthesis of $N$-aroylpyrazolo[1,5-a]pyrimidine-5-amines.

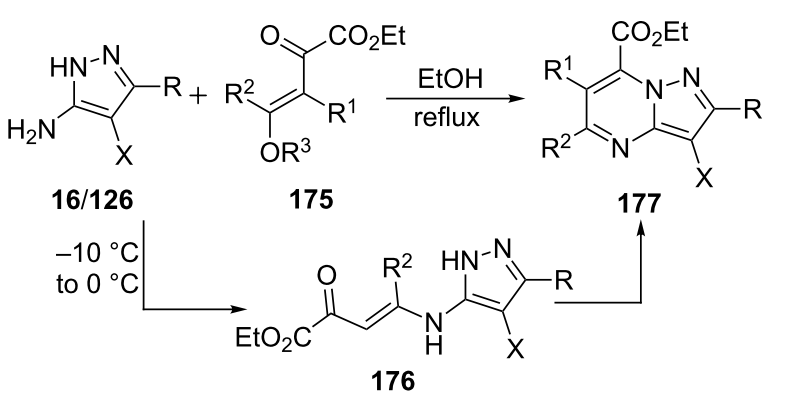

$R^{1}, R^{2}, R=H, M e \quad R^{3}=E t, M e \quad X=H, C O N H_{2}, \mathrm{CO}_{2} E t, C N$

Scheme 49: Regioselective synthesis of ethyl pyrazolo[1,5-a]pyrimidine-7-carboxylate.

[123], cardiovascular [124,125] and tuberculostatic [126,127] activities. The promising therapeutic potential of pyrazolo[3,4d]pyrimidines prompted researchers to develop novel synthetic strategies to provide this class of compounds.

Ghozlan et al. [128] reported the reactions of ethyl 5-amino-3phenylpyrazole-4-carboxylate (126) with benzoylisothiocyanate or phenylisothiocyantes for the synthesis of $N$-thiocarbamoyl pyrazole derivatives $\mathbf{1 8 0}$ and $\mathbf{1 8 3}$ which gave pyrazolo[3,4- $d$ ] pyrimidine derivatives 181 and 184 on treatment with ethanolic sodium ethoxide. Pyrazolo[3,4- $d]$ pyrimi- dine derivatives $\mathbf{1 8 1}$ were also obtained directly by fusion of thiourea/urea with 5-aminopyrazole $\mathbf{1 2 6}$ in an oil bath at $120^{\circ} \mathrm{C}$. $N$-Thiocarbamoyl pyrazole derivatives $\mathbf{1 8 0}$ and $\mathbf{1 8 3}$ underwent cyclization with hydrazine hydrate to give 5-( $N$-triazolyl)aminopyrazole derivative $\mathbf{1 8 2}$ and hydrazinopyrazolo[3,4d] pyrimidines $\mathbf{1 8 5}$, respectively (Scheme 51 ).

El-Moghazy et al. [129] described the synthesis of pyrazolo[3,4- $d$ ] pyrimidine derivatives $\mathbf{1 8 7}$ using a similar approach by the reaction of ethyl 5-amino-1-phenyl- $1 H$-pyrazolo4-carboxylate (186) and phenyl isothiocyanate in pyridine. The pyrazolo[3,4- $d$ ] pyrimidine derivative $\mathbf{1 8 7}$ thus obtained was methylated with iodomethane in acetone in the presence of potassium carbonate to give methyl thioether 188 which provided hydrazinopyrazolo[3,4- $d]$ pyrimidines 189 on treatment with an excess of hydrazine hydrate in ethanol. The hydrazine derivative $\mathbf{1 8 9}$ thus obtained was made to react with several carbonyl compounds like aldehydes, benzoyl chloride and ethyl acetoacetate to append hydrazone, carbohydrazide and pyrazolone type moieties on pyrazolo[3,4- $d]$ pyrimidine. Further, hydrazinyl derivative 189 provided various fused triazolylpyrazolo[3,4$d]$ pyrimidines on treatment with various reagents like aliphatic acids, benzoyl chlorides, chloroacetyl chloride, isothiocyanate and carbon disulfide under appropriate reaction conditions (Scheme 52).<smiles>[R]c1cc(-c2coc3c([R])c([R])c([R])c([R])c3c2=O)cc([R7])c1[R]</smiles>

178<smiles>[R]c1cc(-c2cnc3c(C#N)cnn3c2-c2c([R])c([R])c([R])c([R])c2[R])cc([R])c1[R]</smiles>

$\mathrm{R}^{1}=\mathrm{H}, \mathrm{Br}$

$\mathrm{R}^{2}=\mathrm{OiPr}, \mathrm{OMe}, \mathrm{OBn}$

$\mathrm{R}^{3}=\mathrm{H}, \mathrm{OMe}$

$\mathrm{R}^{4}=\mathrm{H}, \mathrm{Me}, \mathrm{OMe}$

$\mathrm{R}^{5}=\mathrm{H}, \mathrm{iPr}, \mathrm{Br}$

$\mathrm{R}^{6}=\mathrm{H}, \mathrm{OMe}, \mathrm{OBn}, \mathrm{OH}$

$\mathrm{R}^{7}=\mathrm{H}, \mathrm{iPr}, \mathrm{Br}$ 


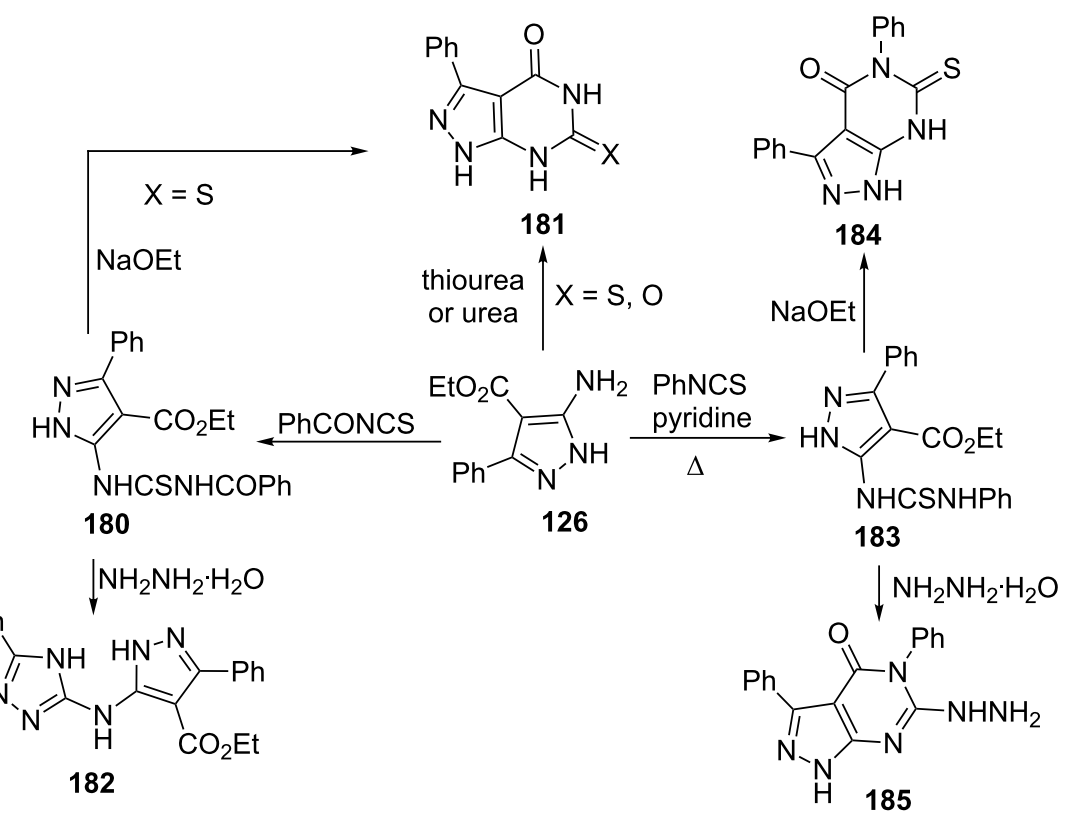

Scheme 51: Synthesis of various pyrazolo[3,4-d]pyrimidine derivatives.

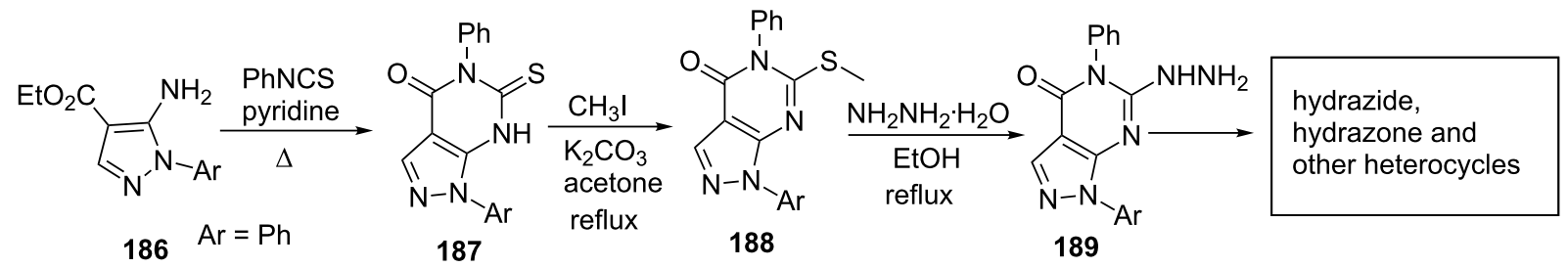

Scheme 52: Synthesis of hydrazinopyrazolo[3,4- $d]$ pyrimidine derivatives.

Hassan et al. [130] reported the synthesis of various pyrazolo[3,4-d]pyrimidine derivatives 193 (Scheme 53). 5-Aminopyrazole-4-carboxylic acid 190 on refluxing in acetic anhydride provided pyrazolooxazinones 191 which converted to 5-aminopyrazolo[3,4- $d$ ]pyrimidine 192 by reaction with hydrazine hydrate in $n$-butanol. Further treatment of 192 with aromatic aldehydes provided the corresponding Schiff base $\mathbf{1 9 3}$.
Singla et al. [131] reported the synthesis of pyrazolo[3,4d]pyrimidinyl-4-amines 198 possessing 4-(1H-benzimidazol-2$\mathrm{yl}$ )phenylamine moiety at $\mathrm{C} 4$ position and primary as well as secondary amines at $\mathrm{C} 6$ position starting from 5-aminopyrazole-4-carboxamide (194). Compound 194 was treated with urea to give $1 H$-pyrazolo[3,4- $d]$ pyrimidine- $4,6(5 H, 7 H)$-dione (195) followed by chlorination with $\mathrm{POCl}_{3}$ to furnish 4,6-di-

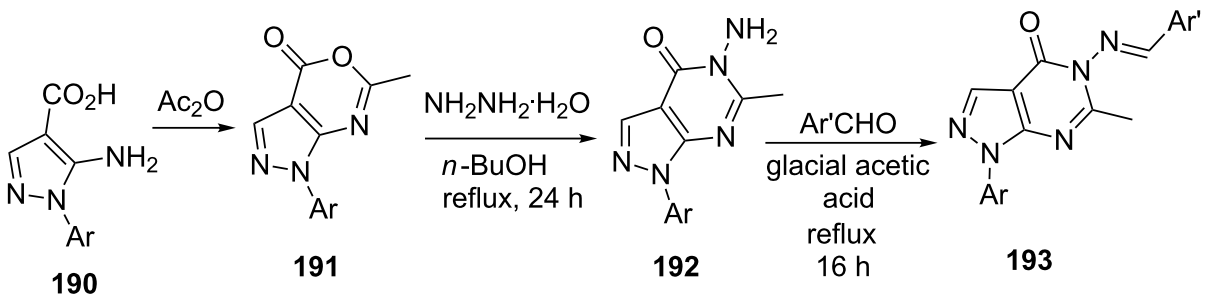

$\mathrm{Ar}=4-\mathrm{Cl}-\mathrm{Ph} \quad \mathrm{Ar}=\mathrm{Ph}, 4-\mathrm{MeO}-\mathrm{Ph}, 3-\mathrm{MeO}-4-\mathrm{OH}-\mathrm{Ph}, 3,4-$ diMeO-Ph, 3,4,5-triMeO-Ph 
chloropyrazolo[3,4- $d]$ pyrimidine (196) which on coupling with the corresponding amines provided [4-(1H-benzimidazol-2-yl)phenyl]-(6-substituted-1 $H$-pyrazolo[3,4- $d]$ pyrimidin-4-yl)amines 198 (Scheme 54). Pyrazolo[3,4-d]pyrimidine derivatives 198 were evaluated for their antitumor activities against various human cancer cell lines. The compound 198 with a pyrrolidine moiety was identified as most potent and promising member as it showed superior antitumor activities over other derivatives.

Bakavoli et al. [115] reported the synthesis of pyrazolo[3,4$d$ ]pyrimidine derivatives $\mathbf{2 0 0}$ from the cyclocondensation of 5-amino-1-(2,4-dinitrophenyl)-1 $H$-pyrazole-4-carboxamide (199) with aromatic aldehydes in the presence of iodine in acetonitrile (Scheme 55). The synthesized pyrazolo[3,4$d]$ pyrimidines were evaluated for antibacterial activities.

Venkatesan et al. [132] also used 4-carboxamide-5-aminopyrazole 199 for the synthesis of pyrazolo[3,4- $d$ ] pyrimidines $\mathbf{2 0 7}$ (Scheme 56). The condensation of 199 with benzoyl isothiocyanate under reflux conditions in dry acetone provided benzoylthioureido derivatives $\mathbf{2 0 1}$ which were converted to methylthio derivative $\mathbf{2 0 2}$ with iodomethane in aqueous sodium hydroxide solution at ambient temperature. The methylthio group was converted to benzoylguanidino derivative $\mathbf{2 0 3}$ by nucleophilic displacement with ammonia in DMF on vigorous heating in a sealed tube. Subsequently, compounds 203 were converted to 6-amino-2-substituted- $2 H$-pyrazolo[3,4- $d]$ pyrimidin-4(5H)-one derivatives 204 by refluxing in $1 \mathrm{~N}$ sodium hydroxide. Pyrazolo[3,4- $d$ ]pyrimidinone 204 were further chlorinated by phosphorus oxychloride and subsequently converted to carboxylic esters $\mathbf{2 0 7}$ via cyanation followed by hydrolysis and esterification.

Kaplan et al. [20] explored the synthesis of pyrazolo[3,4d]pyrimidine derivatives starting from 5-amino-4-cyanopyrazoles 208 (Scheme 57). 5-Amino-4-cyanopyrazole 208 was benzoylated with $p$-nitrobenzoyl chloride (209) and subsequently cyclized to pyrazolo[3,4- $d$ ]pyrimidine derivative 211 by refluxing in sodium hydroxide and hydrogen peroxide. Chlorination of pyrazolo[3,4- $d]$ pyrimidine derivative 211 with phosphorus oxychloride afforded 4-chloro-1H-pyrazolo[3,4d]pyrimidine derivative 212. The chloro and nitro groups were manipulated to introduce a 3,6-dihydropyran group at position-4<smiles>[R]Nc1nc(N([R])[R])nc2[nH]ncc12</smiles><smiles>[R][R]N[R]</smiles><smiles>[R]=Cc1ccc(-c2nc3ccccc3[nH]2)cc1</smiles>

Scheme 54: Synthesis of pyrazolo[3,4-d]pyrimidinyl-4-amines

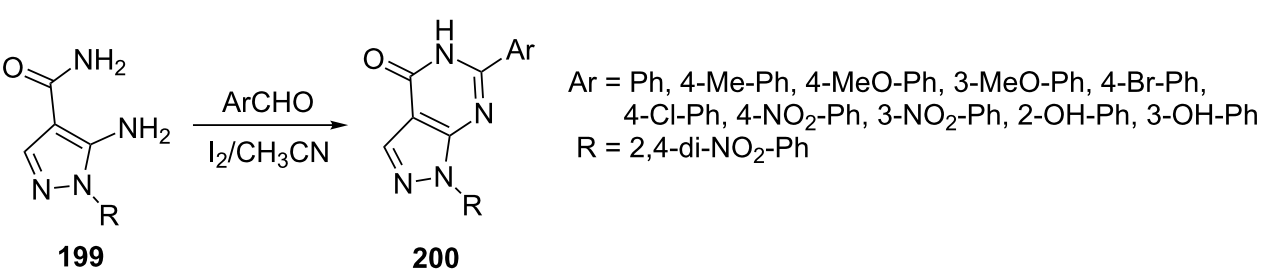


<smiles></smiles>

199<smiles>CS/C=N\C(=O)c1ccccc1</smiles><smiles>[R]n1cc(C(N)=O)c(NC)n1</smiles>

202

$\mathrm{R}=\mathrm{Me}, \mathrm{iPr}$, neopentyl, $\mathrm{CH}_{2} \mathrm{CH}_{2} \mathrm{Ph}$<smiles>[R]n1cc2c(C(=O)OCC)nc(N)nc2n1</smiles>

207 i) $\mathrm{K}_{2} \mathrm{CO}_{3}, \mathrm{H}_{2} \mathrm{O}_{2}$

ii) $\mathrm{EtOH}$

conc. $\mathrm{H}_{2} \mathrm{SO}_{4}$ reflux, $12 \mathrm{~h}$<smiles>[R]n1cc2c(C#N)nc(N)nc2n1</smiles>

206
$\mathrm{R}$

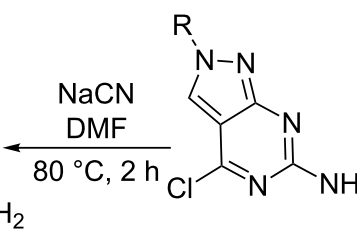

205<smiles>[R]n1cc(C(N)=O)c(N/C(N)=N/C(=O)c2ccccc2)n1</smiles>

$1 \mathrm{~N} \mathrm{NaOH}$ reflux, $12 \mathrm{~h}$

$\mathrm{R}$

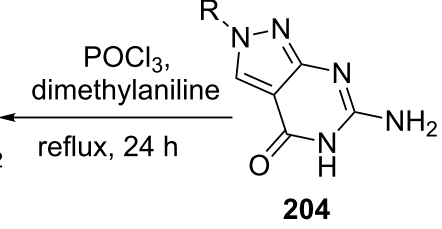

Scheme 56: Synthesis of ethyl 6-amino-2H-pyrazolo[3,4-d]pyrimidine-4-carboxylate.<smiles>[R1]c1c(N)cnn1N</smiles><smiles>O=C(Cl)c1ccc([N+](=O)[O-])cc1</smiles>

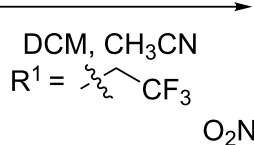<smiles>N#Cc1cnn(CC(F)(F)F)c1NC(=O)c1ccc(F)cc1</smiles><smiles>CCO[N+]([O-])(O)O[Na]</smiles><smiles>O=[N+]([O-])c1ccc(-c2nc(O)c3cnn(CC(F)(F)F)c3n2)cc1</smiles>

211<smiles>[R]NC(=O)Nc1ccc(-c2nc(C3=CCOCC3)c3cnn(CC(F)(F)F)c3n2)cc1</smiles><smiles>[R16]Nc1ccc(C(=N)N)cc1</smiles><smiles>CCn1ncc2c(C3=CCOCC3)ncnc21</smiles>

214<smiles>[R]N=NCNCCC(F)(F)F</smiles>

Scheme 57: Synthesis of 4-substituted-(3,6-dihydropyran-4-yl)-1H-pyrazolo[3,4- $₫]$ pyrimidines.

by Stille reaction which provided 4-(4-(3,6-dihydropyran-4-yl)$1 H$-pyrazolo[3,4- $d$ ]pyrimidin-6-yl)aniline 214 by $\mathrm{NO}_{2}$ group reduction with $\mathrm{H}_{2}, \mathrm{Pd} / \mathrm{C}$ followed by Boc protection, coupling with tributyl(3,6-dihydro-2H-pyran-4-yl)stannane (213) and subsequent Boc deprotection with TFA in DCM. Pyrazolo[3,4d] pyrimidinylaniline 214 was used to synthesize pyrazolo[3,4d]pyrimidinylureas 215 on treatment with triphosgene and corresponding amines.

Liu et al. [133] reported the synthesis of 4-amino-1-(2,4dichlorophenyl)pyrazolo[3,4- $d$ ]pyrimidine derivatives 217 by the reaction of ethyl $\mathrm{N}$-(4-cyano-1-(2,4-dichlorophenyl)- $1 \mathrm{H}$ - pyrazol-5-yl)formimidate (216) with ammonia. $N$-(4-Cyano-1(2,4-dichlorophenyl)-1 $H$-pyrazol-5-yl)formimidate (216), in turn was obtained by reaction of 5-amino-1-(2,4-dichlorophenyl)-1H-pyrazole-4-carbonitrile (208) with trimethylorthoformate. 4-Amino-1-(2,4-dichlorophenyl)pyrazolo[3,4-d]pyrimidine derivatives 217 were coupled with various carboxylic acids in the presence of EDCl, DMAP and HOBt in $N, N$ dimethylformamide at room temperature for the synthesis of the corresponding amide derivatives 218 (Scheme 58).

Song et al. [134] explored the synthesis of pyrazolo[3,4d]pyrimidine derivatives 221 through the intermediacy of 


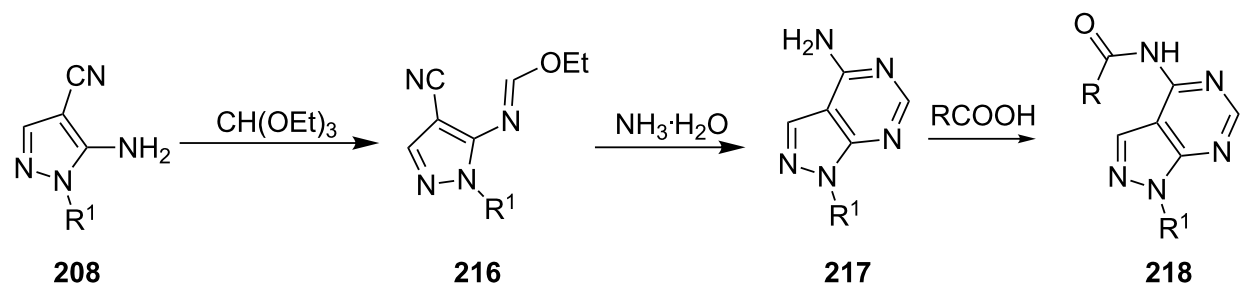

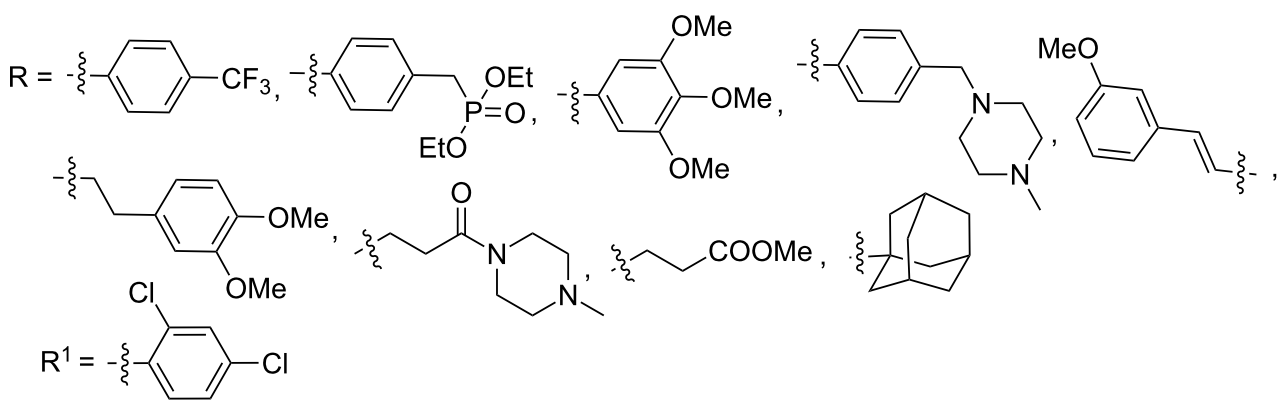

Scheme 58: Synthesis of 1-(2,4-dichlorophenyl)pyrazolo[3,4-d]pyrimidin-4-yl carboxamides.

amidines 219 obtained by reaction of 5-amino-4-cyanopyrazole 208 with $N, N$-dimethylformamide dimethyl acetal (DMFDMA) in acetonitrile at reflux temperature. Amidines 219 were condensed with appropriate 2-amino-5-subsitituted-1,3,4-thiadiazoles 220 under microwave irradiation in acetic acid for the generation of the desired pyrazolo[3,4- $d]$ pyrimidine derivatives 221 (Scheme 59). The synthesized pyrazolo[3,4- $d]$ pyrimidines 221 were proved to be good anticancer agents by MTT assay against HL-60 cancer cell lines.

Zhang et al. [135] reported the reaction of 5-amino-4-cyanopyrazole 208 and aliphatic acids $\left(\mathrm{R}^{2} \mathrm{COOH}\right)$ in the presence of $\mathrm{POCl}_{3}$ to afford the respective 1-arylpyrazolo[3,4- $\left.d\right]$ pyrimidin4-ones 222 in a one pot single step procedure (Scheme 60). $\mathrm{POCl}_{3}$ acted as chlorinating agent as well as an oxidant in the reaction which in situ generated acyl chlorides from acids making the condensation and cyclization easier and faster.

The reaction of 5-amino-4-cyanopyrazole (208) and formamide was carried out by Todorovic et al. [136] under microwave irra-

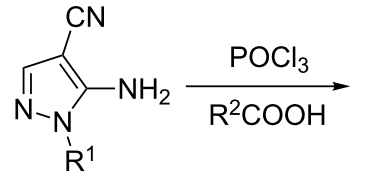

208<smiles>[R]c1nc2c(cnn2[R])c(=O)[nH]1</smiles>

222

$\mathrm{R}^{1}=\mathrm{H}, n-\mathrm{Bu}, 2-\mathrm{Cl}-\mathrm{Ph}, 2,4,6-$ tri-Cl-Ph, 2,4-di- $-\mathrm{NO}_{2}-\mathrm{Ph}$ 4-MeO-Ph, 2,6-di-Cl-4- $\mathrm{CF}_{3}-\mathrm{Ph}$

$\mathrm{R}^{2}=\mathrm{H}, \mathrm{CH}_{3}, \mathrm{CH}_{2} \mathrm{CH}_{3}$

Scheme 60: One pot $\mathrm{POCl}_{3}$-catalyzed synthesis of 1-arylpyrazolo[3,4d]pyrimidin-4-ones.

diation at $200{ }^{\circ} \mathrm{C}$ to give 4-aminopyrazolo[3,4- $\left.d\right]$ pyrimidine (223) which on iodination with $N$-iodosuccinimide followed by N1-alkylation (Mitsunobu or substitution) provided corresponding $N 1$-alkyl-3-iodopyrazolo[3,4- $d]$ pyrimidine derivatives 225. The iodinated pyrazolo[3,4- $d]$ pyrimidines were alkylated at $\mathrm{C} 3$ with boronic acids $\left(\mathrm{R}_{2}-\mathrm{B}(\mathrm{OH})_{2}\right)$ using Suzuki coupling conditions to give 4-amino- $N 1, C 3$-dialkylpyrazolo[3,4-d]pyrimidines 226 (Scheme 61).

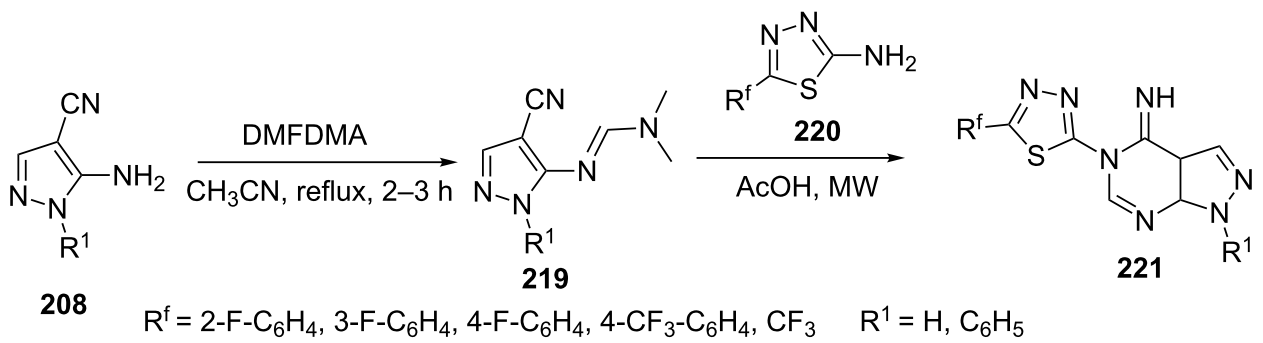


<smiles>N#Cc1cn(CC(N)=O)nc1N</smiles>
$208 R^{1}=H$<smiles></smiles>

223<smiles>Nc1ncnc2[nH]nc(I)c12</smiles>

224<smiles></smiles>

$\mathrm{R}-\mathrm{X}, \mathrm{K}_{2} \mathrm{CO}_{3}$

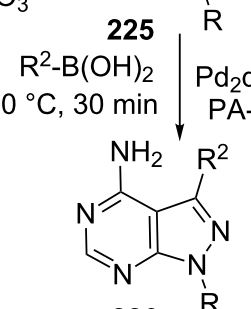

$\mathrm{R}=\mathrm{CH}_{3}, \mathrm{CH}_{2} \mathrm{CH}\left(\mathrm{CH}_{3}\right)_{2}, \mathrm{CH}_{2} \mathrm{CH}_{2} \mathrm{CH}_{2} \mathrm{CH}_{3}, \mathrm{CH}_{2} \mathrm{CH}_{2} \mathrm{CH}_{2} \mathrm{CH}_{2} \mathrm{CH}_{2} \mathrm{CH}_{3}$ $\mathrm{R}^{2}=\mathrm{H}, \mathrm{Ph}$, 4-Me-Ph, 4-MeO-Ph, 4-F-Ph, 2-Cl-Ph, 3-Cl-Ph, 4-Cl-Ph, 3,4-diCl-Ph, $1 H$-indol-6-yl, benzo[ $d][1,3]$ dioxol-5-yl

\section{Synthesis of pyrazolo[3,4-b]pyrazines}

Pyrazolo[3,4-b]pyrazines have received great attention because of their interesting biological activities such as inhibition of protein kinases [137], blood platelet aggregation [138], bone metabolism improvers [139] as well as antifungal [140], antibacterial [141], antiparasitic [142] and antiviral [143] activity. There are several methods reported in literature for the construction of pyrazolo[3,4-b]pyrazine nucleus.

Quiroga et al. [144] studied the reaction of $o$-aminonitrosopyrazoles $\mathbf{2 2 7}$ and cyclic $\beta$-diketones $\mathbf{5 8}$ in various solvents like pyridine, acetic acid and $N, N$-dimethylformamide for the synthesis of pyrazolo[3,4-b]pyrazines $\mathbf{2 2 8}$ (Scheme 62). No measurable product was observed in acetic acid and pyridine but reaction in DMF provided promising results with good yields of the pyrazolo[3,4- $b$ ]pyrazines $\mathbf{2 2 8}$ in short reaction time. The reaction under microwave irradiation $(100 \mathrm{~W}$ at $80{ }^{\circ} \mathrm{C}$ ) in DMF provided the desired product in $85 \%$ yield in just 9 min. Easy work-up, mild reaction conditions and good yields makes this protocol a simple procedure for the synthesis of pyrazolo[3,4- $b]$ pyrazines.

Emary et al. [145] described the cyclocondensation of 5-amino4-nitrosopyrazoles $\mathbf{2 2 9}$ and $\beta$-ketonitriles $\mathbf{1 5}$ in pyridine to give 1,3,6-trisubstitutedpyrazolo[3,4- $b]$ pyrazine-5-carbonitriles 230 in good yields. 5-Carbonitrilepyrazolo[3,4- $b]$ pyrazines 230 were hydrolyzed to corresponding pyrazolo[3,4-b]pyrazine-5carboxylic acids 231 and subsequently converted to acid chloride $\mathbf{2 3 2}$ at reflux temperature with thionyl chloride $\left(\mathrm{SOCl}_{2}\right)$ which underwent intramolecular Friedel-Crafts reaction in presence of Lewis acid to give 3-methyl-1-phenyl-1H-indeno[2,1$e$ ]pyrazolo[3,4-b]pyrazin-5-one (233). Compound 233 was used to synthesize several other indenopyrazolopyrazinone derivatives by reaction with active methylene compounds, aromatic amines, hydroxylamine hydrochloride, semicarbazide hydrochloride, thiosemicarbazide, hydrazine hydrate and phenyl hydrazine (Scheme 63).

Similarly, Farghley et al. [146] reported the reaction of 5-amino-4-nitrosopyrazoles 229 and $\beta$-ketonitriles $\mathbf{1 5}$ in pyridine for the synthesis of pyrazolo[3,4-b]pyrazines $\mathbf{2 3 0}$ which was used as synthetic precursor to generate several other substituted pyrazolo[3,4-b]pyrazine derivatives via amidoxime and carbohydrazide intermediates obtained from the reaction of appropriate substrates with nitrile group (Scheme 63).

\section{Synthesis of pyrazolo[ $1,5-a][1,3,5]$ triazine}

Pyrazolo[ $[1,5-a][1,3,5]$ triazine is a well-known class of fused pyrazole derivatives with a broad spectrum of biological activities such as anticancer [147], anti-inflammatory [148], anxi-<smiles>[R]c1cccc(-n2nc([R])c([N+](=O)[O-])c2N)c1</smiles>

227

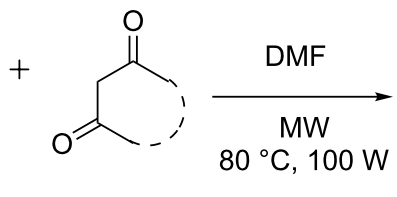

58

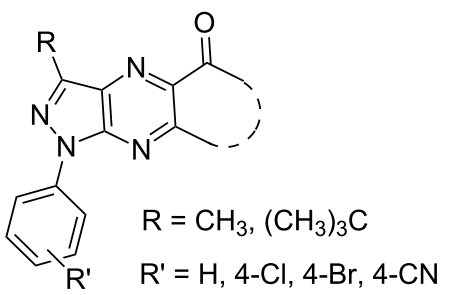

228 


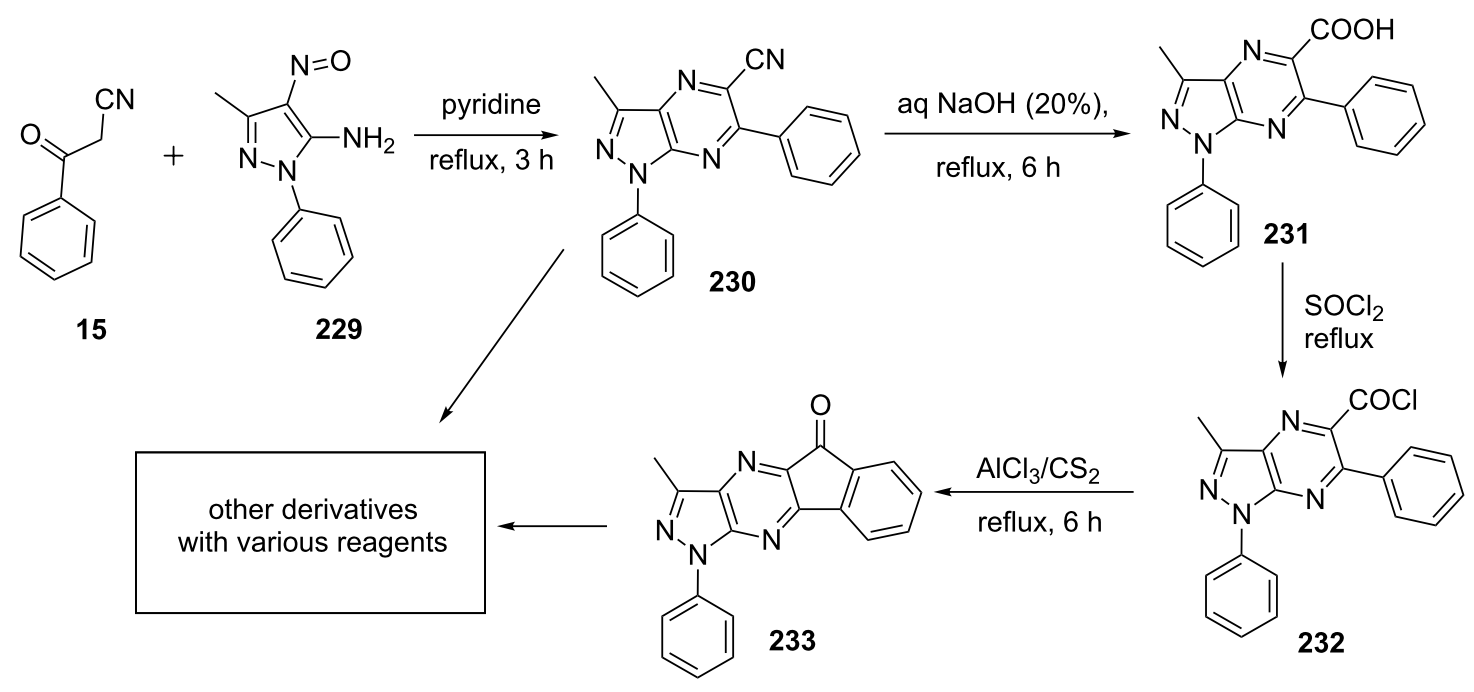

Scheme 63: Synthesis and derivatization of pyrazolo[3,4-b]pyrazine-5-carbonitriles.

olytic [149], anticonvulsant [150] and antidepressant [151]. Accordingly, a large number of synthetic methods have been reported for the construction of pyrazolo[ $[1,5-a][1,3,5]$ triazine derivatives, out of which condensation of the 5-aminopyrazoles with ethoxycarbonyl isothiocyanate/ethoxycarbonyl isocyanates is the most common method for their synthesis.

Bera et al. [152] reported the synthesis of 2-thioxopyrazolo[1,5- $a][1,3,5]$ triazin-4-ones $\mathbf{2 3 6}$ and $\mathbf{2 3 8}$ via annulation of 1,3,5-triazine ring onto 5-aminopyrazoles. The reactions of 5-aminopyrazoles $\mathbf{1 6}$ with ethoxycarbonyl isothiocyanate $\mathbf{2 3 4}$ was carried out in DMF to give thiourea derivatives 235 which on treatment with $\mathrm{NaOH}$ in ethanol underwent cyclization to give 2-thioxo-pyrazolo[ $1,5-a][1,3,5]$ triazin-4-ones $\mathbf{2 3 6}$
(Scheme 64). 3,5-Diaminopyrazoles $\left(\mathrm{R}=\mathrm{NH}_{2}, 15\right)$ following the same reaction sequence led to the formation of 2-thioxopyrazolo[1,5-a][1,3,5]triazin-4-one-6-thiourea derivative $\mathbf{2 3 8}$ through the intermediacy of bithiourea 237 (Scheme 64).

Sun et al. [24] reported the synthesis of 7/8-substituted-2-oxo/ thioxo-2,3-dihydropyrazolo[1,5- $a][1,3,5]$ triazin-4(1H)-one 241 from the reaction of 3/4-substituted-5-aminopyrazoles $\mathbf{1 6 / 1 2 6}$ with ethoxycarbonyl isothiocyanate/ethoxycarbonyl isocyanate $\mathbf{2 3 4} / \mathbf{2 3 9}$, respectively (Scheme 65 ). This two-step procedure involves the intermediacy of ethoxycarbonyl isocyanate to give $N$-ethoxycarbonyl- $N$ '-(pyrazol-3-yl)ureas/thioureas $\mathbf{2 4 0}$ followed by their intramolecular cyclization with sodium ethoxide. The reaction of ethoxycarbonyl isothiocyanate provided higher<smiles>[R]c1n[nH]c(N)c1[R](C)C</smiles>

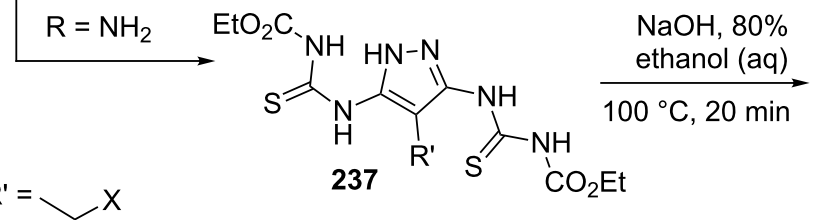
$\mathrm{R}=\mathrm{Ph}, \mathrm{C}(\mathrm{Me})_{3}, 4-\mathrm{CN}-\mathrm{Ph}, 3,4-\mathrm{diCl}-\mathrm{Ph}$

$\mathrm{X}=\mathrm{Ph}, 4-\mathrm{Me}-\mathrm{Ph}, 4-\mathrm{Et}-\mathrm{Ph}, 4-\mathrm{MeO}-\mathrm{Ph}, 4-\mathrm{OH}-\mathrm{Ph}, 4-\mathrm{CN}-\mathrm{Ph}, 4-\mathrm{CF}_{3}-\mathrm{Ph}, 4-\mathrm{F}-\mathrm{Ph}, 4-\mathrm{Cl}-\mathrm{Ph}, 4-\mathrm{Br}-\mathrm{Ph}$, 4-Ph- $\mathrm{C}_{6} \mathrm{H}_{4}$, 4-PhO- $\mathrm{C}_{6} \mathrm{H}_{4}$, naphthyl, furyl, thienyl 


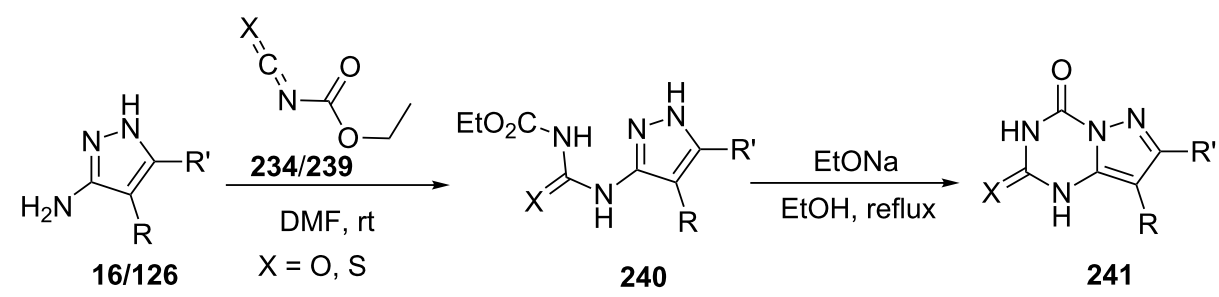

$\mathrm{R}=\mathrm{Me}, \mathrm{Cl}, \mathrm{Br}$, I, Ph, 4-F-Ph, 4-Cl-Ph, 4-Br-Ph, 4-CF $-\mathrm{Ph}$, 4-Me-Ph, 4-MeOPh, 4-EtO-Ph, 4-t-Bu-Ph

4-I-Ph, 4-pentafluorosulfurphenyl

$\mathrm{R}^{\prime}=\mathrm{H}, \mathrm{Me}, t-\mathrm{Bu}, \mathrm{CF}_{3}, \mathrm{Ph}, 4-\mathrm{F}-\mathrm{Ph}, 4-\mathrm{Cl}-\mathrm{Ph}, 4-\mathrm{Br}-\mathrm{Ph}, 4-\mathrm{CF}_{3}-\mathrm{Ph}, 4-\mathrm{Me}-\mathrm{Ph}, 4-t-\mathrm{Bu}-\mathrm{Ph}$

Scheme 65: Synthesis of 2,3-dihydropyrazolo[1,5-a][1,3,5]triazin-4(1H)-one.

yields in short time as compared to the reaction of ethoxycarbonyl isocyanate.

Bakr et al. [153] reported the synthesis of pyrazolo[1,5a] $[1,3,5]$ triazine-8-carboxylic acid ethyl ester 244 from the reaction of aminopyrazolylurea derivative $\mathbf{2 4 2}$ and $\mathrm{N}$-bis(methylthio)methylenecyanamide (243) out in DMF in presence of potassium carbonate (Scheme 66).

Insuasty et al. [154] reported the reaction of 5-aminopyrazoles 246 with thiocarbonates $(\mathbf{2 4 5}, \mathrm{X}=\mathrm{O})$ and dithiocarbonates (245, $\mathrm{X}=\mathrm{S})$ under solvent-free conditions using microwave irradiation $\left(300 \mathrm{~W}, 160-180^{\circ} \mathrm{C}, 10-20 \mathrm{~min}\right)$ to yield a mixture of two products which were characterized as 2-ethylthio/ethoxy4,7-dihetarylpyrazolo[1,5- $a][1,3,5]$ triazines $\mathbf{2 4 7}$ and $\mathbf{2 4 8}$. When the reaction was carried out only for 3 min under similar reaction conditions two isomeric intermediates namely ethyl $N$ '-(heteroaryl-1-carbonyl)- $N$-(3-heteroaryl-1H-pyrazol-5yl)carbamimidothioate/carbamimidate 249 were isolated successfully in $10 \%$ and $24 \%$ yields, respectively (Scheme 67 ). The reactions were also carried under solvent mediated conventional heating conditions which required longer time for completion and provided lower yields of the products.

In an alternative two step path, thiourea derivatives 251 obtained by reaction of 5-aminopyrazoles 246 with heteroarylisothiocyanates 250 were treated with ethyl bromide in presence of sodium hydride in DMF to generate the intermediate isothioureas 252 which on in situ heating provided target diheteroarylpyrazolo[1,5-a][1,3,5]triazines $\mathbf{2 4 7}$ (Scheme 68).<smiles>CCOC(=O)c1c(NC(N)=O)nn2c(N)nc(SC)nc12</smiles>

Scheme 66: Synthesis of pyrazolo[1,5-a][1,3,5]triazine-8-carboxylic acid ethyl ester.

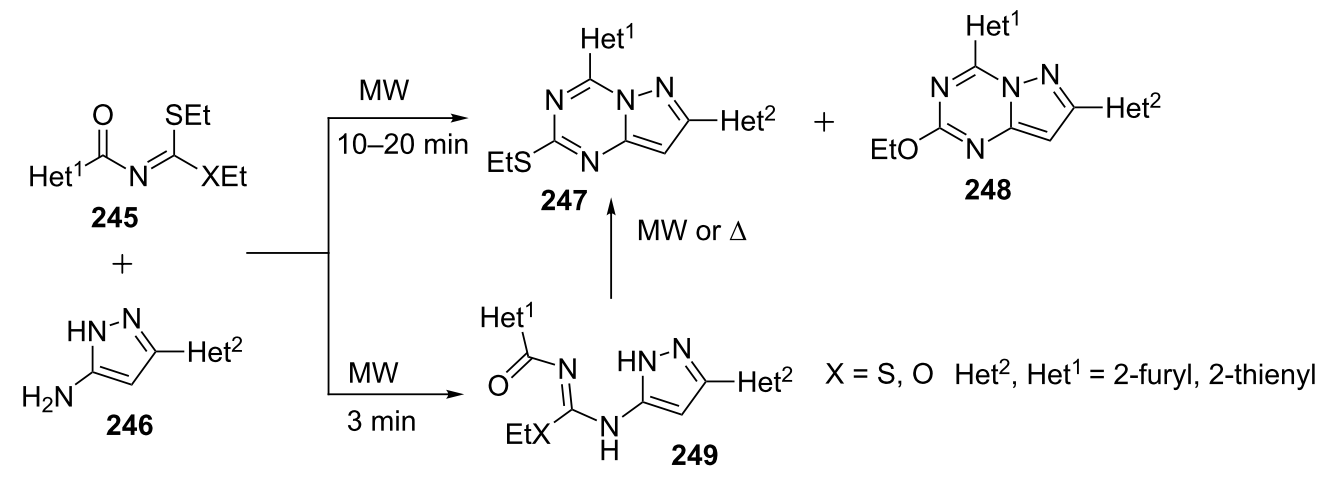




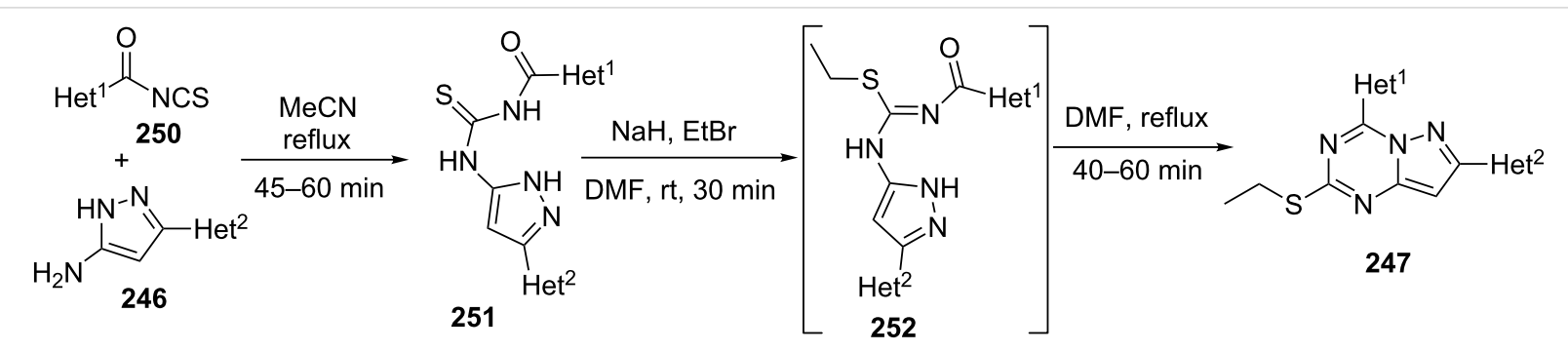

$\operatorname{Het}^{2}$, Het $^{1}=$ 2-furyl, 2-thienyl

Scheme 68: Alternative synthetic route to 4,7-diheteroarylpyrazolo[1,5-a][1,3,5]triazines.

In another report, Insuasty et al. [155] utilized $S, S$-diethyl aroyliminodithiocarbonates $\mathbf{2 4 5}$ for condensation with 5-amino3-methylpyrazole (16) to afford 4-aryl-2-ethylthio-7-methylpyrazolo[1,5-a][1,3,5]triazines $\mathbf{2 4 7 / 2 5 3}$ (Scheme 69). Synthesized pyrazolo[ $1,5-a][1,3,5]$ triazines $\mathbf{2 4 7 / 2 5 3}$ were evaluated for their anticonvulsant profile by exposing on to electrical and chemical experimental seizures induced in ICR albino mice. Pyrazolo[1,5- $a][1,3,5]$ triazines 247 having $\mathrm{R}^{1}, \mathrm{R}^{2}=2$-thienyl, showed a good dose-dependent response in the 50, 150 and $300 \mathrm{mg} / \mathrm{kg}$, p.o., range $(3 / 7,4 / 7,5 / 7 ; \mathrm{p}<0.05)$.

Lim et al. [156] studied the reaction of 3,5-diaminopyrazole derivative 254, cyanamide and triethyl orthoformate in methanol under microwave irradiation (Scheme 70). The reaction resulted in exclusive formation of 4-aminopyrazolo[1,5a] $[1,3,5]$ triazine-8-carbonitriles $\mathbf{2 5 5}$ barring the possibilities of

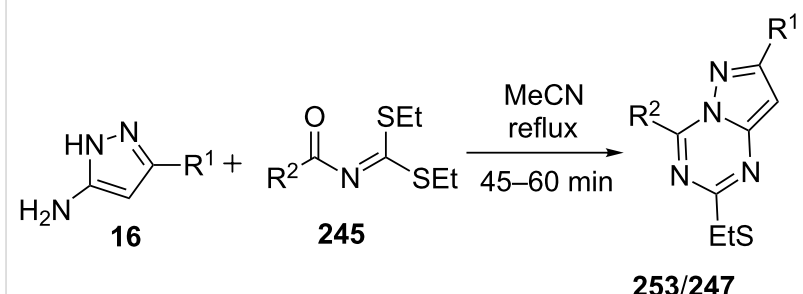

$\mathrm{R}^{1}=\mathrm{H}, \mathrm{Me}, \mathrm{Cl} \mathrm{R}^{2}=\mathrm{Me}$ and $\mathrm{R}^{1}, \mathrm{R}^{2}=$ 2-furyl, 2-thienyl

Scheme 69: Synthesis of 4-aryl-2-ethylthio-7-methylpyrazolo[1,5a] $[1,3,5]$ triazines.

isomeric 2-aminopyrazolo[ $1,5-a][1,3,5]$ triazine 257 and pyrazolo[3,4- $d$ ] pyrimidine derivatives $\mathbf{2 5 8}$ or $\mathbf{2 5 9}$. The formation of 4-aminopyrazolo[1,5-a][1,3,5]triazine derivative 255 was also confirmed by step-wise annulation of a triazine ring with a

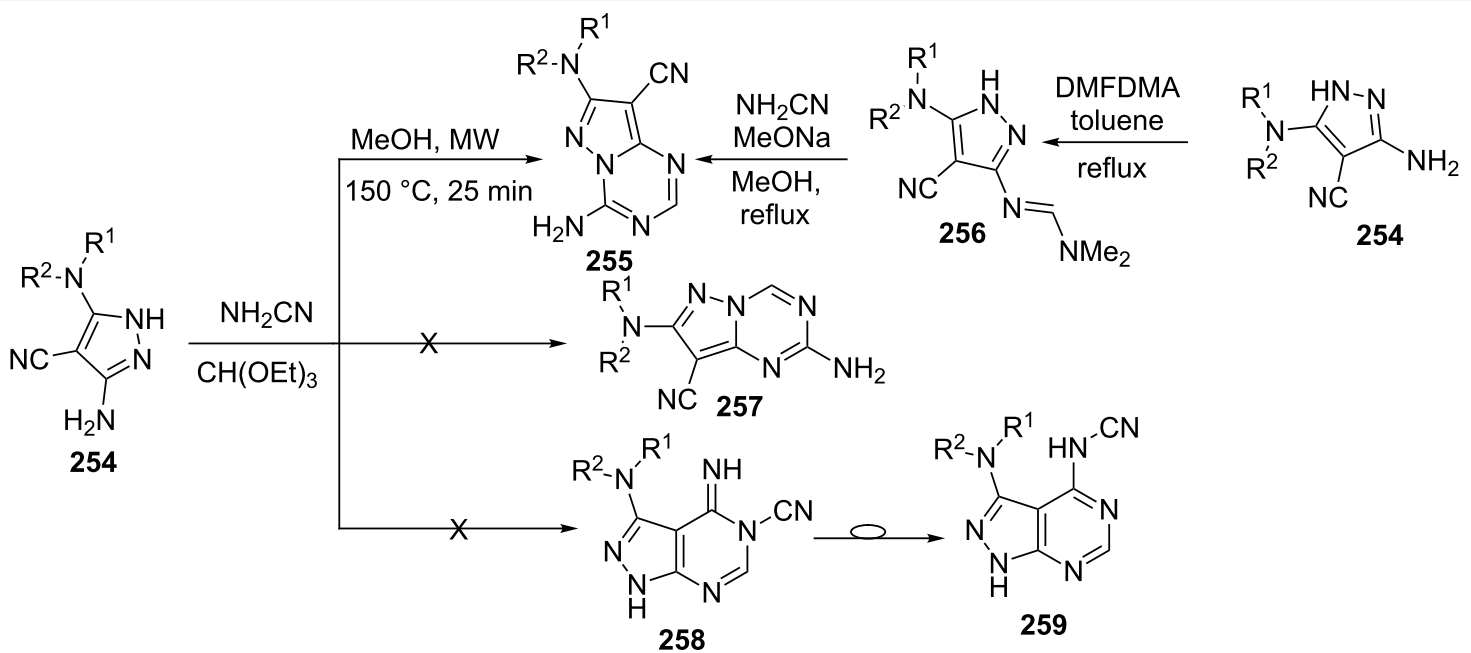

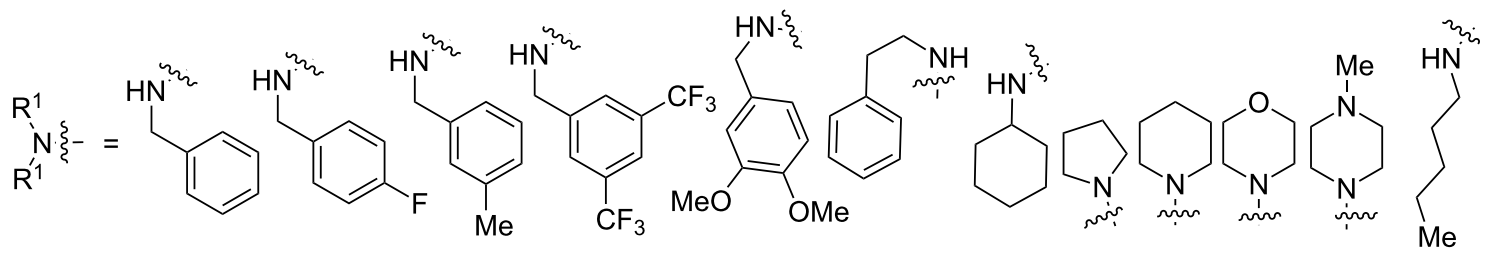


predisposed position of the amino group by converting 5-aminopyrazole 254 into the corresponding formamidine $\mathbf{2 5 6}$ on treatment with $\mathrm{N}, \mathrm{N}$-dimethylformamide dimethyl acetal (DMFDMA) and their subsequent condensation with cyanamide in the presence of sodium methoxide. The one-pot multicomponent method provided two times higher yields than the stepwise method.

\section{Synthesis of pyrazolo[3,4- $d][1,2,3]$ triazine}

Pyrazolo[ $[3,4-d][1,2,3]$ triazines are important fused pyrazole derivatives because of their biological activity and are valuable synthons in organic transformations. These are also structural analogues of adenosine and guanosine [157,158]. But surprisingly, only a few literature reports are available for synthesis and biological potential of this nucleus.

Pyrazolo[3,4- $d][1,2,3]$ triazines 262 were synthesized by Rabie et al. [159] from the diazotization of 4-( $N$-arylcarboxamide)-3( $N$-phenyl)-3,5-diaminopyrazole derivatives $\mathbf{2 6 0}$ with sodium nitrite which underwent in situ cyclization (Scheme 71).

\section{Synthesis of pyrazolo[3,4-e][1,2,4]triazines}

Matar et al. [160] reported that 3-amino-4-phenylhydrazono-1phenyl-2-pyrazolin-5-ones 263 undergo cyclization on refluxing in DMFDMA to afford 2,5-dihydropyrazolo[5,1-c][1,2,4]triazines 264 in good yields (Scheme 72).

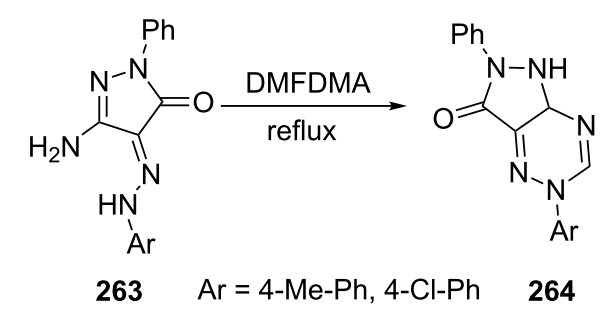

Scheme 72: Synthesis of 2,5-dihydropyrazolo[3,4-e][1,2,4]triazines.

\section{Synthesis of pyrazolo[5,1-c][1,2,4]triazines}

The pyrazolo[5,1-c][1,2,4]triazine nucleus is present in compounds possessing a variety of pharmacological and biological activities [161-163]. The association of biological properties with this nucleus stimulated the interest of organic chemists in the development of novel synthetic approaches for the construction of the pyrazolo[5,1-c][1,2,4]triazine nucleus.

Shawali et al. [164] have reported the synthesis of 3-[(4,5disubstituted-pyrazol-3-yl)carbonyl]-pyrazolo[5,1-c][1,2,4]triazines 269 by cyclization of diazopyrazolylenaminones 268 . 3-Acetylpyrazoles 265 on condensation with DMFDMA provided enaminones 266 which were converted to diazopyrazolylenaminones 268 on coupling with 3-phenylpyrazolyldiazonium salt 267 in pyridine at $0-5{ }^{\circ} \mathrm{C}$. Diazopyrazolylenaminones $\mathbf{2 6 8}$ underwent cyclization under reaction conditions to give pyrazolo[ $[5,1-c][1,2,4]$ triazines $\mathbf{2 6 9}$ (Scheme 73).

Abdelhamid et al. [165] in a similar report synthesized pyrazolo[5,1-c][1,2,4]triazines $\mathbf{2 7 2}$ from the reaction of enaminone 270 with pyrazol-3-yl diazonium salt 271 in ethanolic sodium acetate solution (Scheme 74).

Metwally et al. [166] reported the synthesis of pyrazolo[5,1c] $[1,2,4]$ triazines $\mathbf{2 7 5}, \mathbf{2 7 7}, \mathbf{2 8 0}$ and $\mathbf{2 8 3}$ from coupling of pyrazolyldiazonium salt $\mathbf{2 7 3}$ with various nitrile derivatives $\mathbf{9 4}$, $\beta$-diketones 58, 2-aminoprop-1-ene-1,1,3-tricarbonitrile (278) and 3-methyl-1 $H$-pyrazol-5(4H)-one (281) involving the intermediacy of corresponding hydrazones 274, 276, 279 and 282 in acetic acid or $\mathrm{POCl}_{3} / \mathrm{DMF}$ (Scheme 75).

Adapting a similar procedure Al-Adiwish et al. [167] reported the synthesis of pyrazolo[5,1-c][1,2,4]triazines $\mathbf{2 8 5}$ and $\mathbf{2 8 6}$. 5-Aminopyrazoles 284 were diazotized to the corresponding diazonium salts and subsequently condensed with active methylene 94 and 104 to give hydrazono intermediates which underwent cyclization in acetic acid to provide the desired pyrazolo[5,1-c][1,2,4]triazines $\mathbf{2 8 5}$ and $\mathbf{2 8 6}$, respectively (Scheme 76). Selected pyrazolo[5,1-c][1,2,4]triazines 285 and $\mathbf{2 8 6}$ were screened for antibacterial activity and cytotoxicity against Vero cells.

Schulze et al. [168] reported that 3,4-dinitropyrazole (287) on treatment with trimethylhydrazinium iodide (TMHI) provided

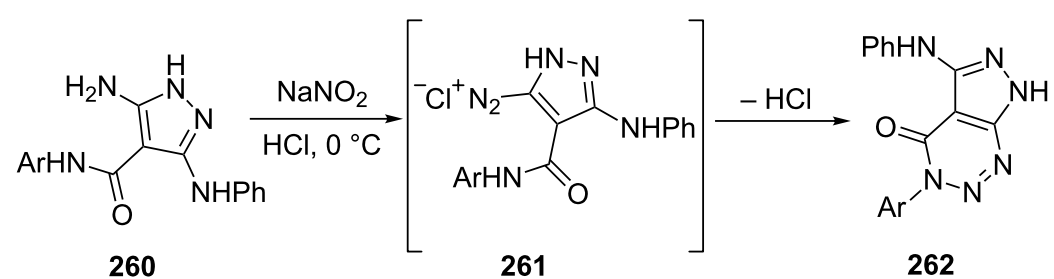


<smiles>[R]C(=O)c1c(C(C)=O)nn(-c2ccccc2)c1-c1ccccc1</smiles>

265<smiles>[R]C(=O)c1c(C(=O)/C=C/N(C)C)nn(-c2ccccc2)c1-c1ccccc1</smiles>

266<smiles>ClNc1cc(-c2ccccc2)n[nH]1</smiles><smiles>[R]C(=O)c1c(C(=O)C(=CN(C)CC)/N=N/c2cc(-c3ccccc3)n[nH]2)nn(-c2ccccc2)c1-c1ccccc1</smiles>

268<smiles>[R]C(=O)c1c(C(=O)c2cn3nc(-c4ccccc4)cc3nn2)nn(-c2ccccc2)c1-c1ccccc1</smiles>

269

Scheme 73: Synthesis of pyrazolo[5,1-c][1,2,4]triazines via diazopyrazolylenaminones.

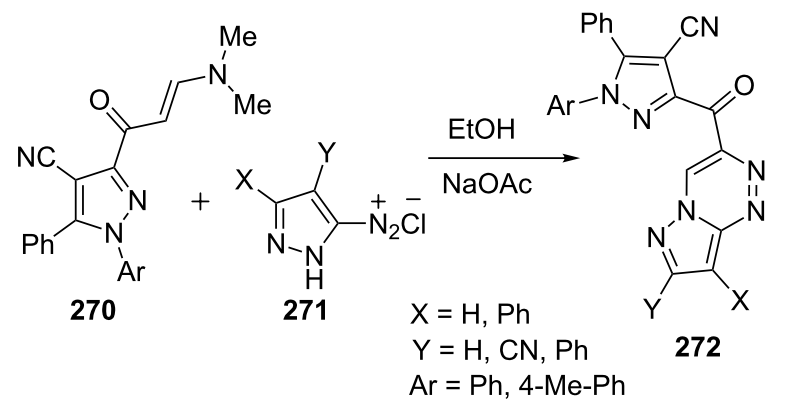

Scheme 74: Synthesis of pyrazolo[5,1-c][1,2,4]triazines in presence of sodium acetate. 5-amino-3,4-dinitropyrazole (288) in 54\% yields. The subsequent diazotization of aminopyrazole $\mathbf{2 8 8}$ and its coupling with sodium salt of nitroacetonitrile provided with $56 \%$ of 4 -amino3,7,8-trinitropyrazolo-[5,1-c][1,2,4]triazine $(\mathbf{2 9 0})$ which has promising explosive properties (Scheme 77).

Ledenyova et al. [169] have reported the synthesis of tricyclic pyrazolo[5,1-c][1,2,4]triazines 294, 297, 300 and 301 from azocoupling reaction of pyrazolediazonium salts 291 with various heterocyclic components, e.g., barbituric acid and thiobarbituric acid 292. Attempts were made to cyclize azocoupled intermediates 293 by heating with polyphosphoric acid (PPA) but only the intermediate formed from barbituric acid $(\mathrm{X}=\mathrm{O})$

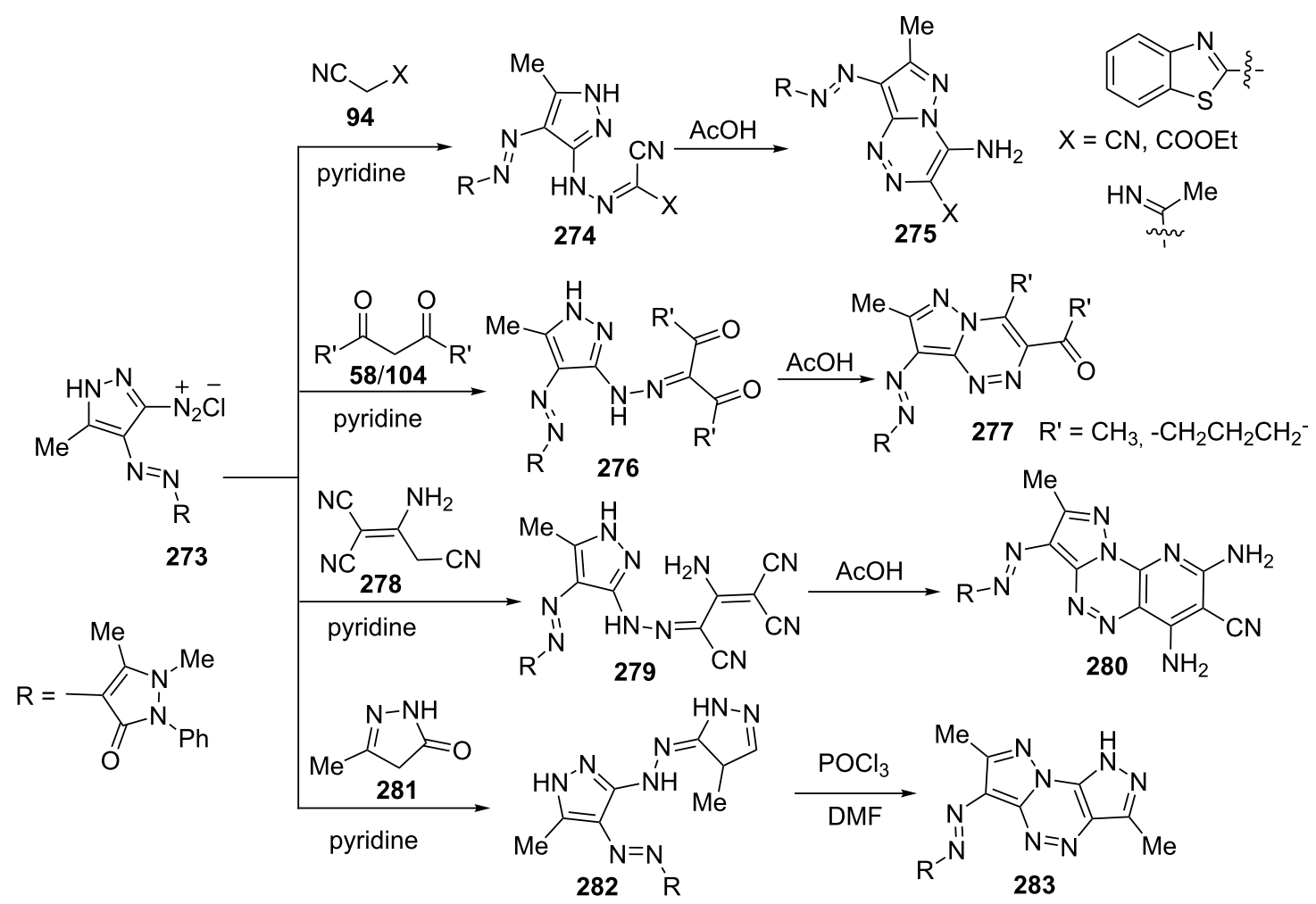

Scheme 75: Synthesis of various 7-diazopyrazolo[5,1-c][1,2,4]triazine derivatives. 
<smiles>Cc1nnc2c(C#N)c(N3CCCC3)nn2c1C</smiles>

285

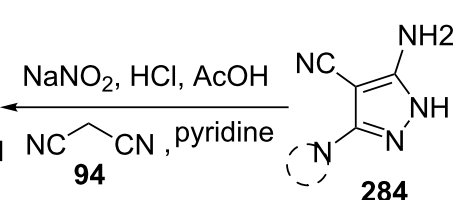

284

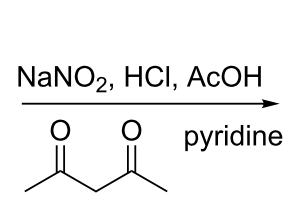

104<smiles>CC(=O)c1nnc2c(C#N)c(N3CCCC3)nn2c1C</smiles>

286<smiles>CN1CCCC1</smiles>

Scheme 76: One pot synthesis of pyrazolo[5,1-c][1,2,4]triazines.

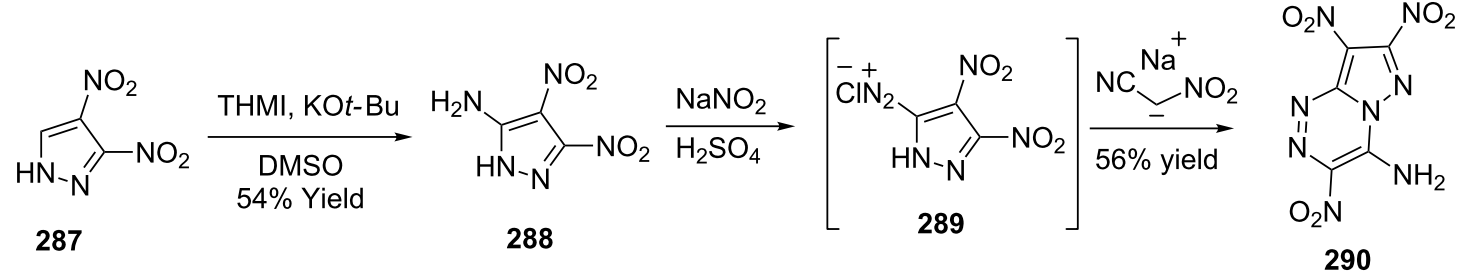

Scheme 77: Synthesis of 4-amino-3,7,8-trinitropyrazolo-[5,1-c][1,2,4]triazines.

provided pyrazolo[5,1-c]pyrimido[4,5-e][1,2,4]triazine-4(3H)- $\quad$ The reaction of pyrazolediazonium salts 291 with 2-hetarylone 294 while the intermediate $(X=S)$ failed to cyclize with pyrimidine-4,6-diones 295 in the presence of sodium acetate in PPA and anhydrous sodium acetate in acetic acid (Scheme 78). acetic provided coloured compounds 296 which underwent

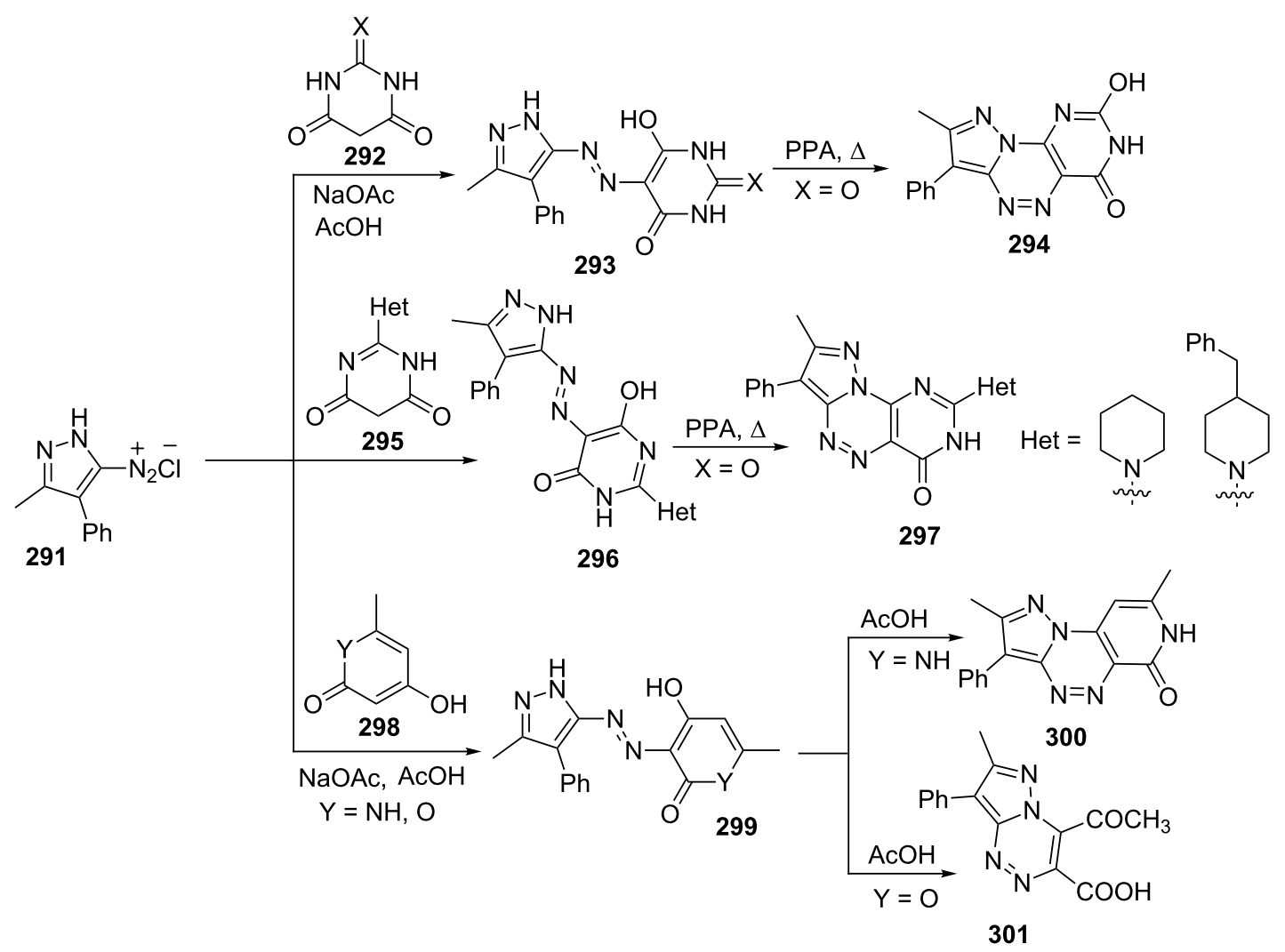


smooth cyclization on heating with PPA to give 8-methyl-7phenyl-2-hetaryl-pyrazolo[5,1-c]pyrimido[4,5-e][1,2,4]triazin$4(3 H)$-ones 297 in $65-70 \%$ yields.

The coupling reaction of 4-hydroxy-6-methyl-1H-pyridine-2one 4-hydroxy-6-methyl-2H-pyran-2-one (triacetic acid, 298) with pyrazolediazonium salts 291 provided pyrazolo[5,1c] $[1,2,4]$ triazine derivatives $\mathbf{3 0 0}$ through the intermediacy of azo coupled product 299. While 4-hydroxy-6-methyl-2H-pyran2-one $(\mathbf{2 9 8}, \mathrm{Y}=\mathrm{O})$ underwent cyclization differently with formation of bicyclic carboxylic acid derivative of pyrazolo[5,1c] $[1,2,4]$ triazine 301 probably due to lactone ring opening (Scheme 78).

\section{Conclusion}

In this review article, we have systematically summarized various synthetic methods developed in the last decade for the construction of various pyrazoloazines as a group of fused pyrazolo derivatives utilizing 5 -aminopyrazole as a synthetic precursor. The 5-aminopyrazole nucleus possesses ubiquitous distinctive structural features and its coupling reactions with different types of electrophilic reagents like aldehydes, ketones, $\beta$-diketones, $\beta$-ketoesters, and $\alpha, \beta$-unsaturated ketones truly justifies its synthetic potential to construct fused heterocycles. This review opens the scope for future developments in new methodologies which promise the synthesis of novel fused heterocyclic systems with a wide range of medicinal and synthetic applications.

\section{Acknowledgements}

We thank the University Grants Commission, New Delhi for the financial assistance to Suresh Kumar as Rajiv Gandhi National Fellowship.

\section{References}

1. Kumar, H.; Saini, D.; Jain, S.; Jain, N. Eur. J. Med. Chem. 2013, 70 , 248-258. doi:10.1016/j.ejmech.2013.10.004

2. Gomha, S. M.; Edrees, M. M.; Faty, R. A. M.; Muhammad, Z. A.; Mabkhot, Y. N. Chem. Cent. J. 2017, 11, No. 37. doi:10.1186/s13065-017-0266-4.

3. Aggarwal, R.; Bansal, A.; Rozas, l.; Kelly, B.; Kaushik, P.; Kaushik, D. Eur. J. Med. Chem. 2013, 70, 350-357. doi:10.1016/j.ejmech.2013.09.052

4. Aggarwal, R.; Kumar, S.; Kaushik, P.; Kaushik, D.; Gupta, G. K. Eur. J. Med. Chem. 2013, 62, 508-514. doi:10.1016/j.ejmech.2012.11.046

5. Mukarram, S.; Bandgar, B. P.; Shaikh, R. U.; Ganapure, S. D.; Chavan, H. V. Med. Chem. Res. 2017, 26, 262-273. doi:10.1007/s00044-016-1744-2

6. Kumar, V.; Aggarwal, R.; Tyagi, P.; Singh, S. P. Eur. J. Med. Chem. 2005, 40, 922-927. doi:10.1016/j.ejmech.2005.03.021
7. Aggarwal, R.; Bansal, A.; Rozas, I.; Diez-Cecilia, E.; Kaur, A.; Mahajan, R.; Sharma, J. Med. Chem. Res. 2014, 23, 1454-1464. doi:10.1007/s00044-013-0751-9

8. Aggarwal, R.; Kumar, R.; Kumar, S.; Garg, G.; Mahajan, R.; Sharma, J. J. Fluorine Chem. 2011, 132, 965-972. doi:10.1016/j.jfluchem.2011.07.029

9. Saad, H. A.; Osman, N. A.; Moustafa, A. H. Molecules 2011, 16, 10187-10201. doi:10.3390/molecules161210187

10. El-sabbhag, O. I.; Baraka, M. M.; Ibrahim, S. M.; Pannecouque, C.; Andrei, G.; Snoeck, R.; Balzarini, J.; Rashad, A. A. Eur. J. Med. Chem. 2009, 44, 3746-3753. doi:10.1016/j.ejmech.2009.03.038

11. Ouyang, G.; Chen, Z.; Cai, X.-J.; Song, B.-A.; Bhadury, P. S.; Yang, S.; Jin, L.-H.; Xue, W.; Hu, D.-Y.; Zeng, S. Bioorg. Med. Chem. 2008, 16, 9699-9707. doi:10.1016/j.bmc.2008.09.070

12. Aggarwal, R.; Kumar, V.; Gupta, G. K.; Kumar, V. Med. Chem. Res. 2013, 22, 3566-3573. doi:10.1007/s00044-012-0343-0

13. Bekhit, A. A.; Ashour, H. M. A.; Ghany, Y. S. A.; Bekhit, A. E.-D. A.; Baraka, A. Eur. J. Med. Chem. 2008, 43, 456-463. doi:10.1016/j.ejmech.2007.03.030

14. Bebernitz, G. R.; Argentieri, G.; Battle, B.; Brennan, C.; Balkan, B.; Burkey, B. F.; Eckhardt, M.; Gao, J.; Kapa, P.; Strohschein, R. J.; Schuster, H. F.; Wilson, M.; Xu, D. D. J. Med. Chem. 2001, 44, 2601-2611. doi:10.1021/jm010032c

15. Yadava, U.; Shukla, B. K.; Roychoudhury, M.; Kumar, D. J. Mol. Model. 2015, 21, 96. doi:10.1007/s00894-015-2631-3

16. Manikannan, R.; Venkatesan, R.; Muthusubramanian, S.; Yogeeswari, P.; Sriram, D. Bioorg. Med. Chem. Lett. 2010, 20, 6920-6924. doi:10.1016/j.bmcl.2010.09.137

17. Özdemir, A.; Altıntop, M. D.; Kaplancıklı, Z. A.; Can, Ö. D.; Özkay, Ü. D.; Turan-Zitouni, G. Molecules 2015, 20, 2668-2684. doi:10.3390/molecules20022668

18. Zhang, L.; Balan, G.; Barreiro, G.; Boscoe, B. P.; Chenard, L. K.; Cianfrogna, J.; Claffey, M. M.; Chen, L.; Coffman, K. J.; Drozda, S. E.; Dunetz, J. R.; Fonseca, K. R.; Galatsis, P.; Grimwood, S.; Lazzaro, J. T.; Mancuso, J. Y.; Miller, E. L.; Reese, M. R.; Rogers, B. N.; Sakurada, I.; Skaddan, M.; Smith, D. L.; Stepan, A. F.; Trapa, P.; Tuttle, J. B.; Verhoest, P. R.; Walker, D. P.; Wright, A. S.; Zaleska, M. M.; Zasadny, K.; Shaffer, C. L. J. Med. Chem. 2014, 57, 861-877. doi:10.1021/jm401622k

19. Damont, A.; Médran-Navarrete, V.; Cacheux, F.; Kuhnast, B.; Pottier, G.; Bernards, N.; Marguet, F.; Puech, F.; Boisgard, R.; Dollé, F. J. Med. Chem. 2015, 58, 7449-7464. doi:10.1021/acs.jmedchem.5b00932

20. Kaplan, J.; Verheijen, J. C.; Brooijmans, N.; Toral-Barza, L.; Hollander, I.; Yu, K.; Zask, A. Bioorg. Med. Chem. Lett. 2010, 20, 640-643. doi:10.1016/j.bmcl.2009.11.050

21. El-Morsy, A. M.; El-Sayed, M. S.; Abulkhair, H. S. Open J. Med. Chem. 2017, 7, No. 1. doi:10.4236/ojmc.2017.71001

22. Elnagdi, M. H.; Abdel-Galil, F. M.; Riad, B. Y.; Elgemeie, G. E. H. Heterocycles 1983, 20, 2437-2470. doi:10.3987/R-1983-12-2437

23. Guerrini, G.; Ciciani, G.; Cambi, G.; Bruni, F.; Selleri, S.; Besnard, F.; Montali, M.; Martini, C.; Ghelardini, C.; Galeotti, N.; Costanzo, A. Bioorg. Med. Chem. 2007, 15, 2573-2586. doi:10.1016/j.bmc.2007.01.053

24. Sun, L.; Bera, H.; Chui, W. K. Eur. J. Med. Chem. 2013, 65, 1-11. doi:10.1016/j.ejmech.2013.03.063

25. Elmaati, T. M. A.; El-Taweel, F. M. J. Heterocycl. Chem. 2004, 41, 109-134. doi:10.1002/jhet.5570410201 
26. Anwar, H. F.; Elnagdi, M. H. ARKIVOC 2009, No. 1, 198-250. doi:10.3998/ark.5550190.0010.107

27. Aggarwal, R.; Kumar, V.; Kumar, R.; Singh, S. P. Beilstein J. Org. Chem. 2011, 7, 179-197. doi:10.3762/bjoc.7.25

28. Marinozzi, M.; Marcelli, G.; Carotti, A. Mini-Rev. Med. Chem. 2015, 15, 272-299. doi:10.2174/1389557515666150312154536

29. Lee, S.; Park, S. B. Org. Lett. 2009, 22, 5214-5217. doi:10.1021/ol902147u

30. Elnagdi, M. N.; Elmoghayar, M. R. H.; Elgemeie, G. E. H. Adv. Heterocycl. Chem. 1987, 41, 319-376. doi:10.1016/S0065-2725(08)60164-6

31. Huang, S.; Lin, R.; Yu, Y.; Lu, Y.; Connolly, P. J.; Chiu, G.; Li, S.; Emanuel, S. L.; Middleton, S. A. Bioorg. Med. Chem. Lett. 2007, 17, 1243-1245. doi:10.1016/j.bmcl.2006.12.031

32. Chiu, G.; Li, S.; Connolly, P. J.; Middleton, S. A.; Emanuel, S. L.; Huang, S.; Lin, R.; Lu, Y.; N. V. Janssen Pharmaceutica, Belgium. PCT Int. Appl. WO 2006130673, Dec 7, 2006.

33. Gudmundsson, K. S.; Johns, B. A.; Wang, Z.; Turner, E. M.; Allen, S. H.; Freeman, G. A.; Boyd, F. L., Jr.; Sexton, C. J.; Selleseth, D. W.; Moniri, K. R.; Creech, K. L. Bioorg. Med. Chem. 2005, 13, 5346-5361. doi:10.1016/j.bmc.2005.05.043

34. Abdel-Monem, Y. K.; El-Enein, S. A. A.; El-Sheikh-Amer, M. M. J. Mol. Struct. 2017, 1127, 386-396. doi:10.1016/j.molstruc.2016.07.110

35. Straub, A.; Stasch, J.-P.; Alonso-Alija, C. Bioorg. Med. Chem. Lett. 2001, 11, 781-784. doi:10.1016/S0960-894X(01)00073-7

36. Elnagdi, M. H.; Negm, A. M.; Sadek, K. U. Synlett 1994, 27-37. doi:10.1055/s-1994-22729

37. Quiroga, J.; Alvarado, M.; Insuasty, B.; Moreno, R.; Raviña, E.; Estevez, I.; De Almeida S., R. H. J. Heterocycl. Chem. 1999, 36 1311-1316. doi:10.1002/jhet.5570360533

38. Quiroga, J.; Hormaza, A.; Insuasty, B.; Márquez, M. J. Heterocycl. Chem. 1998, 35, 409-412. doi:10.1002/jhet.5570350225

39. Rao, H. S. P.; Adigopula, L. N.; Ramadas, K. ACS Comb. Sci. 2017, 19, 279-285. doi:10.1021/acscombsci.6b00156

40. Lee, S.; Park, S. B. Org. Lett. 2009, 11, 5214-5217. doi:10.1021/ol902147u

41. Bou-Petit, E.; Picas, E.; Puigjaner, C.; Font-Bardia, M.; Ferrer, N.; Sempere, J.; de la Bellacasa, R. P.; Batllori, X.; Teixidó, J.; Estrada-Tejedor, R.; y Cajal, S. R.; Borrell, J. I. ChemistrySelect 2017, 2, 3668-3672. doi:10.1002/slct.201700732

42. Aggarwal, R.; Kumar, V.; Bansal, A.; Sanz, D.; Claramunt, R. M. J. Fluorine Chem. 2012, 140, 31-37. doi:10.1016/j.jfluchem.2012.04.007

43. Ghaedi, A.; Bardajee, G. R.; Mirshokrayi, A.; Mahdavi, M.; Shafiee, A.; Akbarzadeh, T. RSC Adv. 2015, 5, 89652-89658. doi:10.1039/C5RA16769H

44. Shi, D.-Q.; Zhou, Y.; Liu, H. Synth. Commun. 2010, 40, 3660-3668. doi:10.1080/00397910903471796

45. Shi, D.-Q.; Yang, F. J. Chin. Chem. Soc. 2008, 55, 755-760. doi:10.1002/jccs.200800113

46. Shi, D.-Q.; Ni, S.-N.; Yang, F.; Shi, J.-W.; Dou, G.-L.; Li, X.-Y.; Wang, X.-S. J. Heterocycl. Chem. 2008, 45, 653-660. doi:10.1002/jhet.5570450303

47. Chen, J.; Liu, W.; Ma, J.; Xu, H.; Wu, J.; Tang, X.; Fan, Z.; Wang, P J. Org. Chem. 2012, 77, 3475-3482. doi:10.1021/jo3002722

48. Prakash, R.; Shekarrao, K.; Saikia, P.; Gogoi, S.; Boruah, R. C. RSC Adv. 2015, 5, 21099-21102. doi:10.1039/C4RA17190J
49. Shekarrao, K.; Kaishap, P. P.; Saddanapu, V.; Addlagatta, A.; Gogoi, S.; Boruah, R. C. RSC Adv. 2014, 4, 24001-24006. doi:10.1039/C4RA02865A

50. Pandey, G.; Bhowmik, S.; Batra, S. Org. Lett. 2013, 15, 5044-5047. doi:10.1021/ol4023722

51. Abdel-Aziz, H. A.; Saleh, T. S.; El-Zahabi, H. S. A. Arch. Pharm. 2010, 343, 24-30. doi:10.1002/ardp.200900082

52. Yen, W.-P.; Liu, P.-L.; Uramaru, N.; Lin, H.-Y.; Wong, F. F. Tetrahedron 2015, 71, 8798-8803. doi:10.1016/j.tet.2015.09.042

53. Nascimento-Júnior, N. M.; Mendes, T. C. F.; Leal, D. M.; Corrêa, C. M. N.; Sudo, R. T.; Zapata-Sudo, G.; Barreiro, E. J.; Fragaa, C. A. M. Bioorg. Med. Chem. Lett. 2010, 20, 74-77. doi:10.1016/j.bmcl.2009.11.038

54. Jiang, B.; Liu, Y.-P.; Tu, S.-J. Eur. J. Org. Chem. 2011, 3026-3035. doi:10.1002/ejoc.201100127

55. Liu, M.; Yin, G.; Zhu, C.; Yao, C. J. Heterocycl. Chem. 2015, 53, 1617-1625. doi:10.1002/jhet.2473

56. Bazgir, A.; Ahadi, S.; Ghahremanzadeh, R.; Khavasi, H. R.; Mirzaei, P. Ultrason. Sonochem. 2010, 17, 447-452. doi:10.1016/j.ultsonch.2009.09.009

57. Wang, Z.; Gao, L.; Xu, Z.; Ling, Z.; Qin, Y.; Rong, L.; Tu, S.-J. Tetrahedron 2017, 73, 385-394. doi:10.1016/j.tet.2016.12.015

58. Quiroga, J.; Portillo, S.; Pérez, A.; Gálvez, J.; Abonia, R.; Insuasty, B. Tetrahedron Lett. 2011, 52, 2664-2666. doi:10.1016/j.tetlet.2011.03.067

59. De, K.; Bhaumik, A.; Banerjee, B.; Mukhopadhyay, C. Tetrahedron Lett. 2015, 56, 1614-1618. doi:10.1016/j.tetlet.2015.01.163

60. Dandia, A.; Laxkar, A. K.; Singh, R. Tetrahedron Lett. 2012, 53, 3012-3017. doi:10.1016/j.tetlet.2012.03.136

61. Gao, X.; Yang, Z.; Hao, W.-J.; Jiang, B.; Tu, S.-J. J. Heterocycl. Chem. 2017, 54, 2434-2439. doi:10.1002/jhet.2840

62. Hao, Y.; Xu, X.-P.; Chen, T.; Zhao, L.-L.; Ji, S.-J. Org. Biomol. Chem. 2012, 10, 724-728. doi:10.1039/C1OB06624B

63. Anand, D.; Yadav, P. K.; Patel, O. P. S.; Parmar, N.; Maurya, R. K.; Vishwakarma, P.; Raju, K. S. R.; Taneja, I.; Wahajuddin, M.; Kar, S.; Yadav, P. P. J. Med. Chem. 2017, 60, 1041-1059. doi:10.1021/acs.jmedchem.6b01447

64. Insuasty, D.; Abonia, R.; Insuasty, B.; Quiroga, J.; Laali, K. K.; Nogueras, M.; Cobo, J. ACS Comb. Sci. 2017, 19, 555-563. doi:10.1021/acscombsci.7b00091

65. Quiroga, J.; Trilleras, J.; Pantoja, D.; Abonía, R.; Insuasty, B.; Nogueras, M.; Cobo, J. Tetrahedron Lett. 2010, 51, 4717-4719. doi:10.1016/j.tetlet.2010.07.009

66. Nikpassand, M.; Mamaghani, M.; Shirini, F.; Tabatabaeian, K. Ultrason. Sonochem. 2010, 17, 301-305. doi:10.1016/j.ultsonch.2009.08.001

67. Yao, C.-S.; Wang, C.-H.; Jiang, B.; Tu, S.-J. J. Comb. Chem. 2010, 12, 472-475. doi:10.1021/cc100017f

68. Frolova, L. V.; Malik, I.; Uglinskii, P. Y.; Rogelj, S.; Kornienko, A.; Magedov, I. V. Tetrahedron Lett. 2011, 52, 6643-6645. doi:10.1016/j.tetlet.2011.10.012

69. Fan, L.; Yao, C.; Shu, M. Heterocycl. Commun. 2016, 22, 63-67. doi:10.1515/hc-2015-0234

70. Huang, Z.; Hu, Y.; Zhou, Y.; Shi, D. ACS Comb. Sci. 2011, 13, 45-49. doi:10.1021/co1000162

71. El-borai, M. A.; Rizk, H. F.; Abd-Aal, M. F.; El-Deeb, I. Y. Eur. J. Med. Chem. 2012, 48, 92-96. doi:10.1016/j.ejmech.2011.11.038 
72. Hill, M. D.; Fang, H.; Brown, J. M.; Molski, T.; Easton, A.; Han, X.; Miller, R.; Hill-Drzewi, M.; Gallagher, L.; Matchett, M.; Gulianello, M.; Balakrishnan, A.; Bertekap, R. L.; Santone, K. S.; Whiterock, V. J.; Zhuo, X.; Bronson, J. J.; Macor, J. E.; Degnan, A. P. ACS Med. Chem. Lett. 2016, 7, 1082-1086. doi:10.1021/acsmedchemlett.6b00292

73. Hill, M. D. Synthesis 2016, 48, 2201-2204. doi:10.1055/s-0035-1562230

74. Aggarwal, R.; Singh, G.; Kumar, S.; McCabe, T.; Rozas, I. ChemistrySelect 2016, 1, 5990-5994. doi:10.1002/slct.201601201

75. Rahmati, A. Tetrahedron Lett. 2010, 51, 2967-2970. doi:10.1016/j.tetlet.2010.03.109

76. Dandia, A.; Gupta, S. L.; Singh, P.; Quraishi, M. A. ACS Sustainable Chem. Eng. 2013, 1, 1303-1310. doi:10.1021/sc400155u

77. Gunasekaran, P.; Prasanna, P.; Perumal, S. Tetrahedron Lett. 2014, 55, 329-332. doi:10.1016/j.tetlet.2013.11.016

78. Jiang, B.; Ye, Q.; Fan, W.; Wang, S.-L.; Tu, S.-J.; Li, G. Chem. Commun. 2014, 50, 6108-6111. doi:10.1039/C4CC00740A

79. Wang, J.-J.; Feng, X.; Xun, Z.; Shi, D.-Q.; Huang, Z.-B. J. Org. Chem. 2015, 80, 8435-8442. doi:10.1021/acs.joc.5b01314

80. Trapani, G.; Laquintana, V.; Denora, N.; Trapani, A.; Lopedota, A.; Latrofa, A.; Franco, M.; Serra, M.; Pisu, M. G.; Floris, I.; Sanna, E.; Biggio, G.; Liso, G. J. Med. Chem. 2005, 48, 292-305. doi:10.1021/jm049610q

81. Wu, Y.-C.; Zou, X.-M.; Hu, F.-Z.; Yang, H.-Z. J. Heterocycl. Chem. 2005, 42, 609-613. doi:10.1002/jhet.5570420421

82. Aggarwal, R.; Sumran, G.; Garg, N.; Aggarwal, A. Eur. J. Med. Chem. 2011, 46, 3038-3048. doi:10.1016/j.ejmech.2011.04.041

83. Hassan, A. S.; Mady, M. F.; Awad, H. M.; Hafez, T. S. Chin. Chem. Lett. 2017, 28, 388-393. doi:10.1016/j.cclet.2016.10.022

84. Al-Mousawi, S. M.; Mohammad, M. A.; Elnagdi, M. H. J. Heterocycl. Chem. 2001, 38, 989-991. doi: $10.1002 /$ jhet. 5570380430

85. Jakše, R.; Svete, J.; Stanovnik, B.; Golobič, A. Tetrahedron 2004, 60 , 4601-4608. doi:10.1016/j.tet.2004.03.075

86. Lager, E.; Andersson, P.; Nilsson, J.; Pettersson, I.; Nielsen, E. Ø.; Nielsen, M.; Sterner, O.; Liljefors, T. J. Med. Chem. 2006, 49, 2526-2533. doi:10.1021/jm058057p

87. Médran-Navarrete, V.; Damont, A.; Peyronneau, M. A.; Kuhnast, B.; Bernards, N.; Pottier, G.; Marguet, F.; Puech, F.; Boisgard, R.; Dollé, F. Bioorg. Med. Chem. Lett. 2014, 24, 1550-1556. doi:10.1016/j.bmcl.2014.01.080

88. Marjani, A. P.; Khalafy, J.; Salami, F.; Ezati, M. ARKIVOC 2015 No. 5, 277-286. doi:10.3998/ark.5550190.p009.062

89. Aggarwal, R.; Sumran, G.; Claramunt, R. M.; Sanz, D.; Elguero, J. J. Mol. Struct. 2009, 934, 96-102. doi:10.1016/j.molstruc.2009.06.021

90. Aggarwal, R.; Masan, E.; Kaushik, P.; Kaushik, D.; Sharma, C.; Aneja, K. R. J. Fluorine Chem. 2014, 168, 16-24. doi:10.1016/j.jluchem.2014.08.017

91. Mulakayala, N.; Upendar Reddy, C. H.; Chaitanya, M.; Manzoor Hussain, M.; Kumar, C. S.; Golla, N. J. Korean Chem. Soc. 2011, 55, 719-722. doi:10.5012/jkcs.2011.55.4.719

92. Buriol, L.; München, T. S.; Frizzo, C. P.; Marzari, M. R. B.; Zanatta, N.; Bonacorso, H. G.; Martins, M. A. P. Ultrason. Sonochem. 2013, 20, 1139-1143. doi:10.1016/j.ultsonch.2013.02.006

93. Saikia, P.; Gogoi, S.; Boruah, R. C. J. Org. Chem. 2015, 80, 6885-6889. doi:10.1021/acs.joc.5b00933
94. Kamal, A.; Tamboli, J. R.; Nayak, V. L.; Adil, S. F.; Vishnuvardhan, M. V. P. S.; Ramakrishna, S. Bioorg. Med. Chem. Lett. 2013, 23, 3208-3215. doi:10.1016/j.bmcl.2013.03.129

95. Kamal, A.; Faazil, S.; Hussaini, S. M. A.; Ramaiah, M. J.; Balakrishna, M.; Patel, N.; Pushpavalli, S. N. C. V. L.; Pal-Bhadra, M. Bioorg. Med. Chem. Lett. 2016, 26, 2077-2083. doi:10.1016/j.bmcl.2016.02.072

96. Griffith, D. A.; Hargrove, D. M.; Maurer, T. S.; Blum, C. A.; De Lombaert, S.; Inthavongsay, J. K.; Klade, L. E.; Mack, C. M.; Rose, C. R.; Sanders, M. J.; Carpino, P. A. Bioorg. Med. Chem. Lett. 2011, 21, 2641-2645. doi:10.1016/j.bmcl.2010.12.116

97. Dwyer, M. P.; Paruch, K.; Labroli, M.; Alvarez, C.; Keertikar, K. M.; Poker, C.; Rossman, R.; Fischmann, T. O.; Duca, J. S.; Madison, V.; Parry, D.; Davis, N.; Seghezzi, W.; Wiswell, D.; Guzi, T. J. Bioorg. Med. Chem. Lett. 2011, 21, 467-470. doi:10.1016/j.bmcl.2010.10.113

98. Azeredo, L. F. S. P.; Coutinho, J. P.; Jabor, V. A. P.; Feliciano, P. R.; Nonato, M. C.; Kaiser, C. R.; Menezes, C. M. S.; Hammes, A. S. O.; Caffarena, E. R.; Hoelz, L. V. B.; Souza, N. B.; Pereira, G. A. N.; Cerávolo, I. P.; Krettli, A. U.; Boechat, N. Eur. J. Med. Chem. 2017, 126, 72-83. doi:10.1016/j.ejmech.2016.09.073

99. Hylsová, M.; Carbain, B.; Fanfrlík, J.; Musilová, L.; Haldar, S.; Köprülüoğlu, C.; Ajani, H.; Brahmkshatriya, P. S.; Jorda, R.; Kryštof, V.; Hobza, P.; Echalier, A.; Paruch, K.; Lepšík, M. Eur. J. Med. Chem. 2017, 126, 1118-1128. doi:10.1016/j.ejmech.2016.12.023

100.Aggarwal, R.; Kumar, V.; Singh, G.; Sanz, D.; Claramunt, R. M.; Alkorta, I.; Sánchez-Sanz, G.; Elguero, J. J. Heterocycl. Chem. 2015, 52, 336-345. doi:10.1002/jhet.1955

101.Aggarwal, R.; Singh, G.; Kaushik, P.; Kaushik, D.; Paliwal, D.; Kumar, A. Eur. J. Med. Chem. 2015, 101, 326-333. doi:10.1016/j.ejmech.2015.06.011

102. Tian, Y.; Du, D.; Rai, D.; Wang, L.; Liu, H.; Zhan, P.; De Clercq, E.; Pannecouque, C.; Liu, X. Bioorg. Med. Chem. 2014, 22, 2052-2059. doi:10.1016/j.bmc.2014.02.029

103. Kaswan, P.; Pericherla, K.; Purohit, D.; Kumar, A. Tetrahedron Lett. 2015, 56, 549-553. doi:10.1016/j.tetlet.2014.11.121

104. Chobe, S. S.; Dawane, B. S.; Tumbi, K. M.; Nandekar, P. P.; Sangamwar, A. T. Bioorg. Med. Chem. Lett. 2012, 22, 7566-7572. doi:10.1016/j.bmcl.2012.10.027

105. Ahmetaj, S.; Velikanje, N.; Grošelj, U.; Šterbal, I.; Prek, B.; Golobič, A.; Kočar, D.; Dahmann, G.; Stanovnik, B.; Svete, J. Mol. Diversity 2013, 17, 731-743. doi:10.1007/s11030-013-9469-3

106. Abdelhamid, A. O.; Gomha, S. M. J. Chem. 2013, No. 327095. doi:10.1155/2013/327095

107. Mostafa, S. S.; Salem Nada, A. M. M. Eur. Chem. Bull. 2015, 4, 50-59. doi:10.17628/ecb.2015.4.50-59

108.Ren, L.; Laird, E. R.; Buckmelter, A. J.; Dinkel, V.; Gloor, S. L.; Grina, J.; Newhouse, B.; Rasor, K.; Hastings, G.; Gradl, S. N.; Rudolph, J. Bioorg. Med. Chem. Lett. 2012, 22, 1165-1168. doi:10.1016/j.bmcl.2011.11.092

109.Stepaniuk, O. O.; Matviienko, V. O.; Kontratov, I. S.; Vitruk, I. V.; Tolmachev, A. O. Synthesis 2013, 45, 925-930. doi:10.1055/s-0032-1318329

110.Ma, Y.-Q.; Zhang, Z.-T.; He, Q.; Xue, D.; Zhang, P.-F. Synth. Commun. 2012, 42, 933-941. doi:10.1080/00397911.2010.521902 
111.El-Bendary, E. R.; Badria, F. A. Arch. Pharm. 2000, 333, 99-103. doi:10.1002/(SICI)1521-4184(20004)333:4<99::AID-ARDP99>3.0.CO; 2-O

112.Chern, J.-H.; Shia, K.-S.; Hsu, T.-A.; Tai, C.-L.; Lee, C.-C.; Lee, Y.-C.; Chang, C.-S.; Tseng, S.-N.; Shih, S.-R. Bioorg. Med. Chem. Lett. 2004, 14, 2519-2525. doi:10.1016/j.bmcl.2004.02.092

113.Ram, V. J.; Pandey, H. N.; Mishra, L. Arch. Pharm. 1979, 312, 586-590. doi:10.1002/ardp.19793120705

114.Amir, M.; Javed, S.; Kumar, H. Indian J. Pharm. Sci. 2007, 69, 337-343. doi:10.4103/0250-474X.34540

115.Bakavoli, M.; Bagherzadeh, G.; Vaseghifar, M.; Shiri, A.; Pordel, M.; Mashreghi, M.; Pordeli, P.; Araghi, M. Eur. J. Med. Chem. 2010, 45, 647-650. doi:10.1016/j.ejmech.2009.10.051

116. Abunada, N. M.; Hassaneen, H. M.; Kandile, N. G.; Miqdad, O. A. Molecules 2008, 13, 1501-1517. doi:10.3390/molecules13071501

117.Raffa, D.; Maggio, B.; Plescia, F.; Cascioferro, S.; Raimondi, M. V.; Plescia, S.; Cusimano, M. G. Arch. Pharm. 2009, 342, 321-326. doi:10.1002/ardp.200800140

118.Petrie, C. R.; Cottam, H. B.; McKernan, P. A.; Robins, R. K.; Revankar, G. R. J. Med. Chem. 1985, 28, 1010-1016. doi:10.1021/jm00146a007

119.Celano, M.; Schenone, S.; Cosco, D.; Navarra, M.; Puxeddu, E.; Racanicchi, L.; Brullo, C.; Varano, E.; Alcaro, S.; Ferretti, E.; Botta, G.; Filetti, S.; Fresta, M.; Botta, M.; Russo, D. Endocr.-Relat. Cancer 2008, 15, 499-510. doi:10.1677/ERC-07-0243

120.Fallacara, A. L.; Mancini, A.; Zamperini, C.; Dreassi, E.; Marianelli, S.; Chiariello, M.; Pozzi, G.; Santoro, F.; Botta, M.; Schenone, S. Bioorg. Med. Chem. Lett. 2017, 27, 3196-3200. doi:10.1016/j.bmcl.2017.05.015

121.Fu, Y.; Wang, Y.; Wan, S.; Li, Z.; Wang, G.; Zhang, J.; Wu, X. Molecules 2017, 22, 542. doi:10.3390/molecules22040542

122.Wang, C.; Liu, H.; Song, Z.; Ji, Y.; Xing, L.; Peng, X.; Wang, X.; Ai, J.; Geng, M.; Zhang, A. Bioorg. Med. Chem. Lett. 2017, 27, 2544-2548. doi:10.1016/j.bmcl.2017.03.088

123. Hutson, P. H.; Finger, E. N.; Magliaro, B. C.; Smith, S. M.; Converso, A.; Sanderson, P. E.; Mullins, D.; Hyde, L. A.; Eschle, B. K.; Turnbull, Z.; Sloan, H.; Guzzi, M.; Zhang, X.; Wang, A.; Rindgen, D.; Mazzola, R.; Vivian, J. A.; Eddins, D.; Uslaner, J. M.; Bednar, R.; Gambone, C.; Le-Mair, W.; Marino, M. J.; Sachs, N.; Xu, G.; Parmentier-Batteur, S. Neuropharmacology 2011, 61, 665-676. doi:10.1016/j.neuropharm.2011.05.009

124.Guccione, S.; Modica, M.; Longmore, J.; Shaw, D.; Barretta, G. U.; Santagati, A.; Santagati, M.; Russo, F. Bioorg. Med. Chem. Lett. 1996, 6, 59-64. doi:10.1016/0960-894X(95)00558-B

125.Xia, Y.; Chackalamannil, S.; Czarniecki, M.; Tsai, H.; Vaccaro, H.; Cleven, R.; Cook, J.; Fawzi, A.; Watkins, R.; Zhang, H. J. Med. Chem. 1997, 40, 4372-4377. doi:10.1021/jm970495b

126. Trivedi, A.; Dodiya, D.; Surani, J.; Jarsania, S.; Mathukiya, H.; Ravat, N.; Shah, V. Arch. Pharm. 2008, 341, 435-439. doi:10.1002/ardp.200800027

127. Trivedi, A.; Vaghasiya, S.; Dholariya, B.; Dodiya, D.; Shah, V. J. Enzyme Inhib. Med. Chem. 2010, 25, 893-899. doi:10.3109/14756360903540276

128.Ghozlan, S. A. S.; Abdelrazek, F. M.; Mohamed, M. H.; Azmy, K. E. J. Heterocycl. Chem. 2010, 47, 1379-1385. doi:10.1002/jhet.482

129.El-Moghazy, S. M.; George, R. F.; Osman, E. E. A.; Elbatrawy, A. A.; Kissova, M.; Colombo, A.; Crespan, E.; Maga, G. Eur. J. Med. Chem. 2016, 123, 1-13. doi:10.1016/j.ejmech.2016.07.034
130. Hassan, G. S.; Kadry, H. H.; Abou-Seri, S. M.; Ali, M. M.; Mahmoud, A. E. E.-D. Bioorg. Med. Chem. 2011, 19, 6808-6817. doi:10.1016/j.bmc.2011.09.036

131.Singla, P.; Luxami, V.; Singh, R.; Tandon, V.; Paul, K. Eur. J. Med. Chem. 2017, 126, 24-35. doi:10.1016/j.ejmech.2016.09.093

132. Venkatesan, G.; Paira, P.; Cheong, S. L.; Federico, S.; Klotz, K. N.; Spalluto, G.; Pastorin, G. Eur. J. Med. Chem. 2015, 92, 784-798. doi:10.1016/j.ejmech.2015.01.046

133.Liu, J.; Zhang, X.-W.; Song, D.-Z.; Cai, Z.-q.; Zhou, Y.-p. J. Chem. Res. 2016, 40, 63-125. doi:10.3184/174751916X14531173426246

134.Song, X. J.; Shao, Y.; Dong, X. G. Chin. Chem. Lett. 2011, 22, 1036-1038. doi:10.1016/j.cclet.2011.05.012

135.Zhang, X.; Lin, Q.; Zhong, P. Molecules 2010, 15, 3079-3086. doi:10.3390/molecules15053079

136. Todorovic, N.; Awuah, E.; Shakya, T.; Wright, G. D.; Capretta, A. Tetrahedron Lett. 2011, 52, 5761-5763. doi:10.1016/j.tetlet.2011.08.103

137. Binch, H.; Robinson, D.; Miller, A.; Fraysse, D. Pyrrolopyrazines and pyrazolopyrazines useful as inhibitors of protein kinases. WO Patent WO 2006058074, June 1, 2006.

138. Sado, T.; Inoue, A. Chem. Abstr. 1990, 113, 78422k.

139. Imaizumi, K.; Sado, T. Chem. Abstr. 1994, 121, 91797w.

140. El-Emary, T. I. J. Chin. Chem. Soc. 2006, 53, 391-401. doi:10.1002/jccs. 200600050

141.Foks, H.; Pancechowska-Ksepko, D.; Kędzia, A.; Zwolska, Z.; Janowiec, M.; Augustynowicz-Kopeć, E. Farmaco 2005, 60, 513-517. doi:10.1016/j.farmac.2005.05.002

142.El-Kashef, H. S.; El-Emary, T. I.; Gasquet, M.; Timon-David, P.; Maldonado, J.; Vanelle, P. Pharmazie 2000, 55, 572-576.

143. El-Emary, T. I.; Kamal El-Dean, A. M.; El-Kashef, H. S. Farmaco 1998, 53, 383-388. doi:10.1016/S0014-827X(98)00014-7

144.Quiroga, J.; Sánchez, N. E.; Acosta, P.; Insuasty, B.; Abonia, R. Tetrahedron Lett. 2012, 53, 3181-3187. doi:10.1016/j.tetlet.2012.04.083

145.El-Emary, T.; El-Kashef, H. Eur. J. Med. Chem. 2013, 62, 478-485. doi:10.1016/j.ejmech.2013.01.025

146.Farghaly, A.-R.; Esmail, S.; Abdel-Zaher, A.; Abdel-Hafez, A.; El-Kashef, H. Bioorg. Med. Chem. 2014, 22, 2166-2175. doi:10.1016/j.bmc.2014.02.019

147.Nie, Z.; Perretta, C.; Erickson, P.; Margosiak, S.; Lu, J.; Averill, A.; Almassy, R.; Chu, S. Bioorg. Med. Chem. Lett. 2008, 18, 619-623. doi:10.1016/j.bmcl.2007.11.074

148. El-Hawash, S. A.; El-Mallah, A. I. Pharmazie 1998, 53, 368-373.

149. Trincavelli, M. L.; Da Pozzo, E.; Daniele, S.; Martini, C. Curr. Top. Med. Chem. 2012, 12, 254-269. doi:10.2174/1568026799078787

150. Youdim, M. B. H.; Bakhle, Y. S. Br. J. Pharmacol. 2006, 147 (Suppl. S1), S287-S296. doi:10.1038/sj.bjp.0706464

151. Kulkarni, S. K.; Dhir, A. Expert Opin. Invest. Drugs 2009, 18, 767-788. doi:10.1517/13543780902880850

152.Bera, H.; Ojha, P. k.; Tan, B. J.; Sun, L.; Dolzhenko, A. V.; Chui, W.-K.; Chiu, G. N. C. Eur. J. Med. Chem. 2014, 78, 294-303. doi:10.1016/j.ejmech.2014.03.063

153.Abbas-Temirek, H. H.; Abo-Bakr, A. M. Eur. J. Chem. 2016, 7, 107-114. doi:10.5155/eurjchem.7.1.107-114.1369

154. Insuasty, H.; Insuasty, B.; Castro, E.; Quiroga, J.; Abonía, R.; Nogueras, M.; Cobo, J. Tetrahedron 2012, 68, 9384-9390. doi:10.1016/j.tet.2012.09.029 
155. Insuasty, H.; Castro, E.; Escobar, J. C.; Murillo, V.; Rodríguez, J.; Cuca, L. E.; Estrada, M.; Insuasty, B.; Guerrero, M. F. Rev. Colomb. Cienc. Quim.-Farm. 2014, 43, 22-38. doi:10.15446/rcciquifa.v43n1.45462

156. Lim, F. P. L.; Luna, G.; Dolzhenko, A. V. Tetrahedron Lett. 2015, 56, 7016-7019. doi:10.1016/j.tetlet.2015.11.006

157.Seela, F.; Lindner, M.; Glaçon, V.; Lin, W. J. Org. Chem. 2004, 69, 4695-4700. doi:10.1021/jo040150i

158. Migawa, M.; Drach, J.; Townsend, L. J. Med. Chem. 2005, 48, 3840-3851. doi:10.1021/jm0402014

159. Fadda, A. A.; Rabie, R.; Etman, H. A. J. Heterocycl. Chem. 2017, 54, 1015-1023. doi:10.1002/jhet.2669

160.Al-Matar, H. M.; Khalil, K. D.; Al-Dorri, D. M.; Elnagdi, M. H. Molecules 2010, 15, 3302-3310. doi:10.3390/molecules15053302

161.Rusinov, V. L.; Ulomskii, E. N.; Chupakhin, O. N.; Charushin, V. N. Russ. Chem. Bull. 2008, 57, 985-1014. doi:10.1007/s11172-008-0130-8

162.Berger, D. M.; Dutia, M. D.; Hopper, D.; Torres, N. Int. Appl. PCT WO 2009/039387 A1, March 26, 2009.

163. Guerrini, G.; Costanzo, A.; Ciciani, G.; Bruni, F.; Selleri, S.; Costagli, C.; Besnard, F.; Costa, B.; Martini, C.; De Siena, G.; Malmberg-Aiello, P. Bioorg. Med. Chem. 2006, 14, 758-775. doi:10.1016/j.bmc.2005.08.058

164.Shawali, A. S. J. Adv. Res. 2012, 3, 185-188. doi:10.1016/j.jare.2011.07.004

165. Abdelhamid, A. O.; Fahmi, A. A.; Halim, K. N. M. Synth. Commun. 2013, 43, 1101-1126. doi:10.1080/00397911.2011.616639

166. Metwally, M. A.; Gouda, M. A.; Harmal, A. N.; Khalil, A. M. Eur. J. Med. Chem. 2012, 56, 254-262. doi:10.1016/j.ejmech.2012.08.034

167.Al-Adiwish, W. M.; Tahir, M. I. M.; Siti-Noor-Adnalizawati, A.; Hashim, S. F.; Ibrahim, N.; Yaacob, W. A. Eur. J. Med. Chem. 2013, 64, 464-476. doi:10.1016/j.ejmech.2013.04.029

168.Schulze, M. C.; Scott, B. L.; Chavez, D. E. J. Mater. Chem. A 2015, 3, 17963-17965. doi:10.1039/C5TA05291B

169. Ledenyova, I. V.; Didenko, V. V.; Shestakov, A. S.; Shikhaliev, K. S. J. Heterocycl. Chem. 2013, 50, 573-578. doi:10.1002/jhet.1533

\section{License and Terms}

This is an Open Access article under the terms of the Creative Commons Attribution License (http://creativecommons.org/licenses/by/4.0), which permits unrestricted use, distribution, and reproduction in any medium, provided the original work is properly cited.

The license is subject to the Beilstein Journal of Organic Chemistry terms and conditions: (https://www.beilstein-journals.org/bjoc)

The definitive version of this article is the electronic one which can be found at: $\underline{\text { doi:10.3762/bjoc. } 14.15}$ 